فقه مقاصد الشريعة

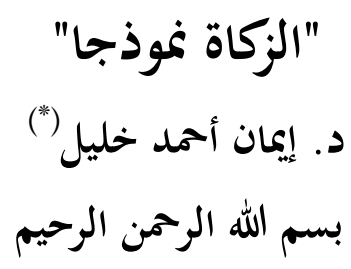

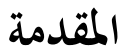

العلم بمقاصد الشريعة علم ضروري لا غنى للفقيه والمجتهد وطالب العلم عنه؛فهو كالبوصلة التي تحدد الطريق والمنار الذي ينير الدرب لهم جميعا، وبدون الفقه بمقاصد الشريعة لا يستقيم الاجتهاد ولا تحقق آليته على الغالب.

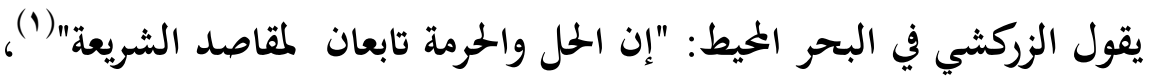

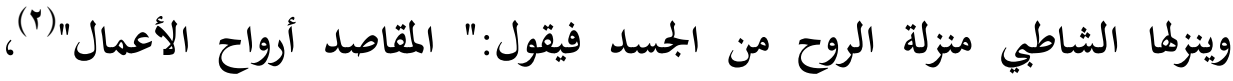

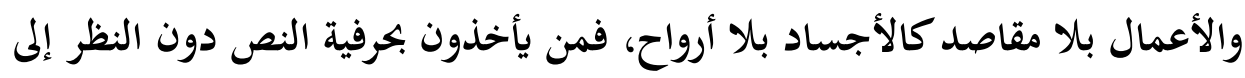

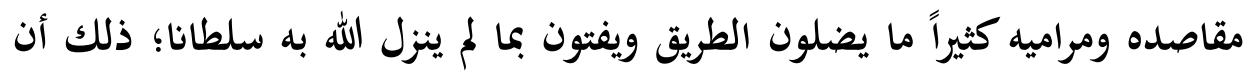
"أولى الحطوات في أي عمل استنباطي، هي النظر في النصوص الشرعية الواردة في

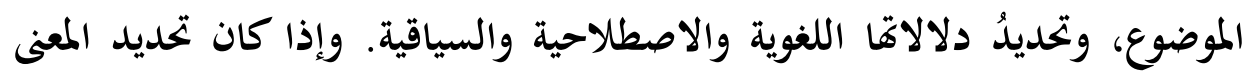

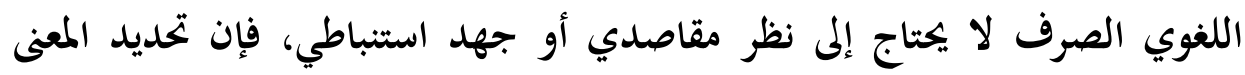

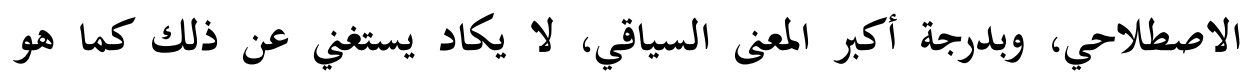

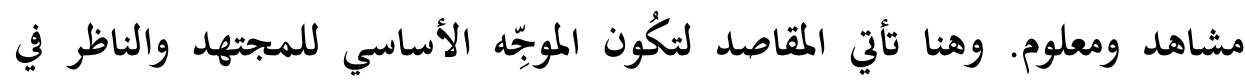

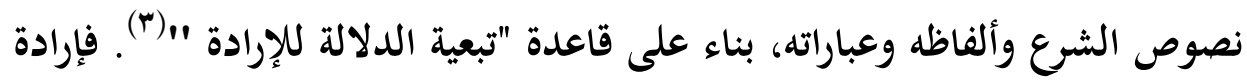

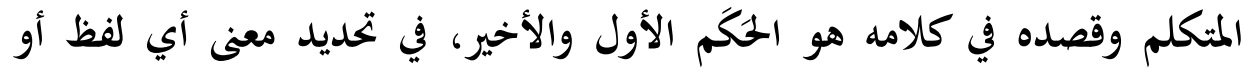
عبارة. - م 
خلاصة المسألة: أن الألفاظ ودلالاتما اللغوية الأصلية، ليست هي المحدد الوحيد للمعاني والدلالات الثرعية، بل لا بد من البحث عن المعنى السياقي ومقاصد الشرع فيه. وهذا هو المنهج الذي سنَّه لنا الصحابة، (๕) كما يقول ابن القيم :"وقد كان الصحابة أفهَمَ الأمِِ لمراد نبيها وأتْبعَ له. وإنما كانوا يدندنون حول معرفة

$$
\text { مراده ومقصوده "(•) }
$$

وهذا ما دفعني لإجراء هذه الدراسة، ومحاولة الارتشاف من هذا المعين العذب،

$$
\begin{aligned}
& \text { راجية من الله - عز وجل - أن يمن علينا بالقبول. } \\
& \text { أهمية البحث: }
\end{aligned}
$$

علم المقاصد من العلوم الشرعية الأساسية التي لا غنى للفقيه والأصولي والمحدث والمفسر وطالب العلوم الثرعية عنها؛ ورسوخ العالم في فقه الكتاب والسنة يتحقق بتمكنه وفقهه مقاصد الشريعة وكلياتما؛ ذلك أن المقاصد هي قبلة الأحكام ومدار فلكها.

وعلم المقاصد علم قديم قدم الوحي، والحاجة إليه في عصرنا أكثر من أي عصر مضى؛ لكثرة الحوادث وتشعب النوازل وتعقدها. ولقد توالت نداءات علماء الأصول المتأخرين والمعاصرين بأهمية التجديد في علم الأصول وما يتفرع عنه من فقه المقاصد الثرعية بتنمية دراستها، والعمل على وضع قواعد أو ضوابط تقي الجزتهدين مزالق الاجتهادات المرجوحة. ومع أهمية هذا العلم لم يتناوله إلا بجموعة من العلماء ما بين الإشارة والتأصيل والتقعيد والشرح وعلى رأسهم الإمام الجويني، والغزالي والعز ابن عبد السلام وابن تيمية وابن القيم والشاطبي ومحمد بن عاشور والفاسي والريسولي.... إلا أن كل هذا يعد قطرة في بحر هذا العلم، الذي يستحق من علماء الأمة التوجه له أفراداً ومؤسسات.

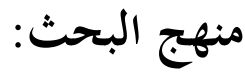


اعتمدت في هذا البحث على عدة من المناهج البحثية، فاستخدمت المنهج

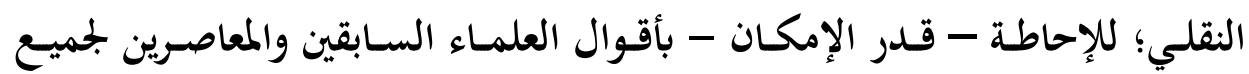

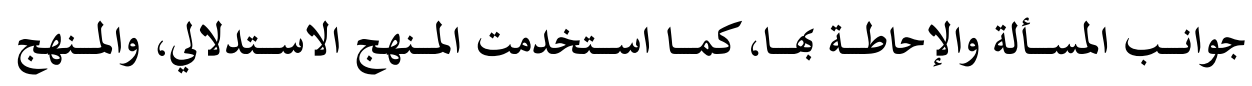

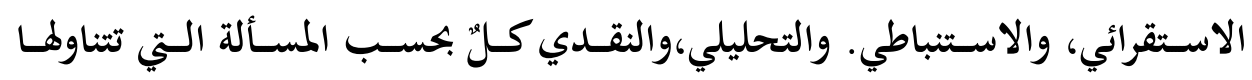
الدراسة.

خطة البحث:

قسمت هذا البحث إلى: مقدمة، ومبحثين، وخاتمة، ثم ذكرت أهم النتائج، وفهرس المادر والمراجع، وذلك على النحو التالي:

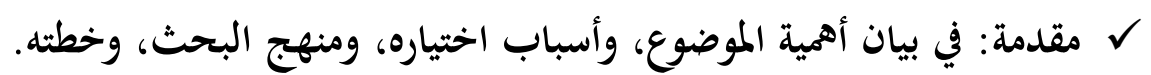

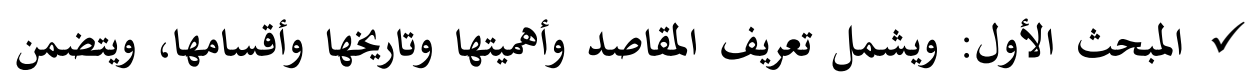
أربعة مطالب:

المطلب الأول: التعريف بالمقاصد الشرعية.

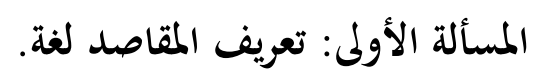

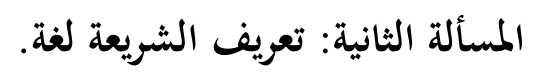
المسألة الثالثة: تعريف الثريعة اصطلاحاً. المسألة الرابعة: تعريف المقاصد الثرعية اصطلاحاً. المطلب الثاني: أهمية مقاصد الثريعة. المطلب الثالث: تاريخ نشأة المقاصد الشرعية.

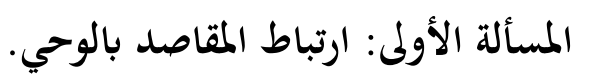

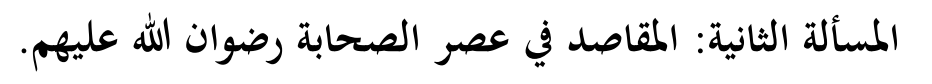
ها المسألة الثالثة: المقاصد في عصر التابعين. المسألة الرابعة: تناول الأصوليين لنظرية المقاصد. 


$$
\text { المطلب الرابع أقسام مقاصد الشريعة. }
$$

ل المبحث الثاني: مقاصد الثريعة في الزكاة، ويتضمن ثمانية مطالب:

$$
\text { • المطلب الأول: مقصد تحقيق العبودية ودفع كل صور الشرك. }
$$

• المطلب الثاني: مقصد إقامة العدل ودفع الظلم. • المطلب الثالث: مقصد التنمية ودفع النقصان والهلاك • المطلب الرابع: مقصد الطهارة ودفع الرذائل والحبائث. • المطلب الخامس:مقصد القوة ودفع الضعف. المطلب السادس: مقصد الأمن ودفع الخوف. • المطلب السابع:مقصد الحرية ودفع الاستعباد. • المطلب الثامن: مقصد الرحمة ودفع القسوة. ل الخاتمة: وفيها أهم النتائج، يتلوها فهرس المصادر والمراجع. والحمد لله الذي هدائ لمذا البحث، والصلاة والسلام على الرحمة المهداة وعلى آله وأصحابه ومن اتبع سنته إلى يوم الدين. 


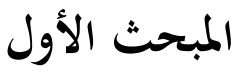

تعريف مقاصد الشريعة، وأهميتها، وتاريخها، وأقسامها

المطلب الأول: تعريف مقاصد الثريعة.

المسألة الأولى: تعريف المقاصد لغةً: القصد استقامة الطريق؛ قصد يقصد

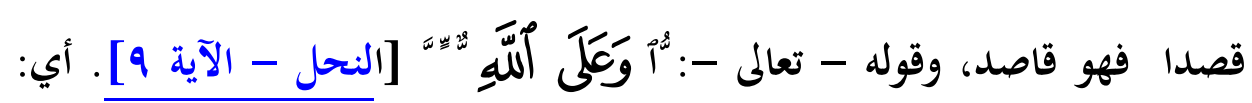

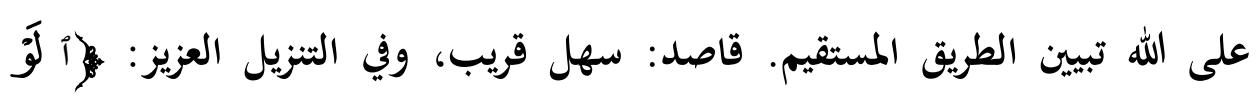

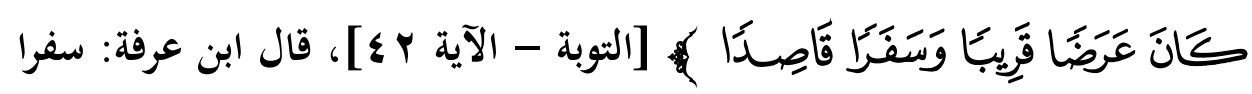
قاصدا. أي: غير شاق.

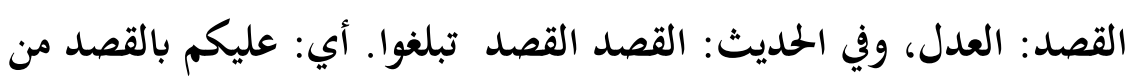
الأمور في القول والفعل، وهو الوسط بين الطرفين.

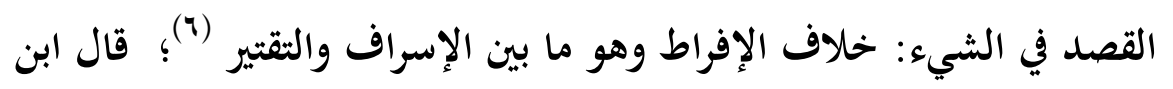

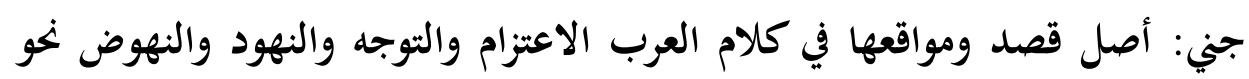
الشيء (v)

المسألة الثانية: تعريف الشريعة لغة: مشرعة الماء وهي مورد الشاربة التي

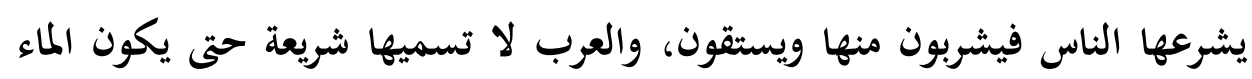

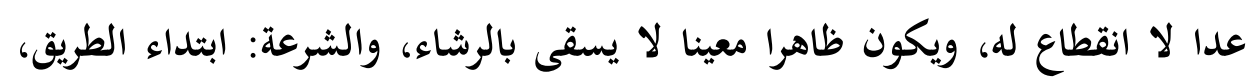

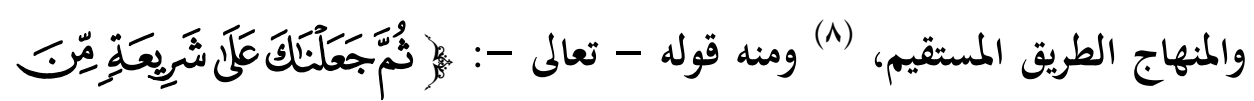

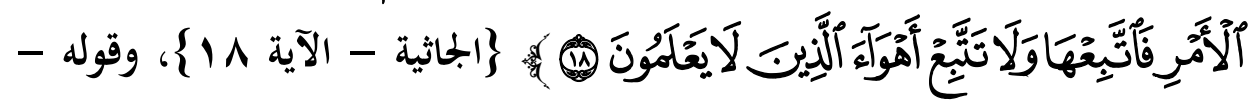

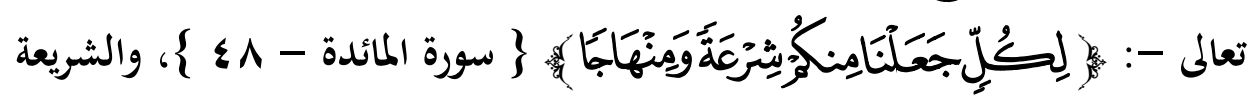
والثرعة: ما سن الله من الدين وأمر به: كالصوم والصلاة والحجج والزكاة وسائر

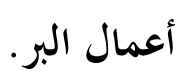




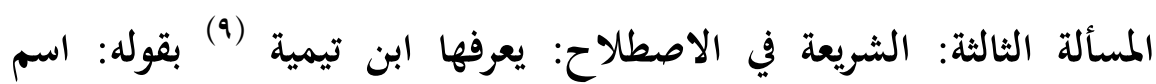

الشريعة والشرع والشرعة فإنه ينتظم كل ما شرعه الله من العقائد والأعمال (·ل). أي: أن الشريعة تجمع بين العقائد والمعاملات والأخلاق، وذكر ابن تيمية أن العلماء المتأخرين في عصره يقصرون الشريعة على الجوانب العملية (المعاملات ) دون العقائدية، ويعرفها الجرجاني (1) بقوله: الثريعة هي الائتمار بالتزام العبودية، وقيل: الشريعة هي الطريق في الدين (rا)، وما أرجحه هو: أن الشريعة تجمع بين العقائد والأخلاق والجوانب العملية ( المعاملات ). المسألة الرابعة: تعريف مقاصد الثريعة الإسلامية:(اصطلاحاً): عرفها محمـد الطاهر ابـن عاشـور بأفها: "المعساني والحكـم الملحوظة للشـارع في جميع أحوال التشريع أو معظمها بجيث لا تختص ملاحظتها بالكون في نوع خحاص من أحكام الشريعة "(r ( ).

و لفظة المعالي مفردها " معنى"، وهو التأويل والتفسير، والمقاصد هي الغايات وهي أوسع وأثمل من التفسير، والمقاصد أثمل من الحكمى؛ لأن الحكم تعني أفضل الكلام " فكل كلمة وعظتك وزجرتك ودعتك إلى مكرمة أو فتتك عن قبيح فهي حكمة" (\&) (1)

وعرفها عـلال الفاسي بقوله: "المـراد بالمقاصـد الثـرعية بأفهـا الغايـة منهـا، والأسرار التي وضعها الشـارع عند كل حكم من أحكامها " (10). و والمقاصد تعـي الفـايات، وهـي أشمل مـن الأسـرار، وكلمـة الأسـرار قـد تفيـد الحخفـاء فتـد تخفى على ججتهد وتظهر لآخر، ومقاصد الشرع أوضح من أن تخفى. وقال نور الدين الخادمي: " هي المعاني الملحوظة في الأحكام الثرعية والمترتبة عليها؛ سواء أكانت تلك المعالي حكما جزئية أم مصالح كلية أم سمات إجمالية، وهي تتجمع ضمن هدف واحد هو تقرير عبودية الله ومصلحة الإنسان في الدارين " (1) ذكرنا فيما سبق أن المقاصد أشمل وأوسع من المعاني. 
كما عرفها الدكتور فتحي الدريني:" المصلحة هي مقصود الشرع والمصلحة

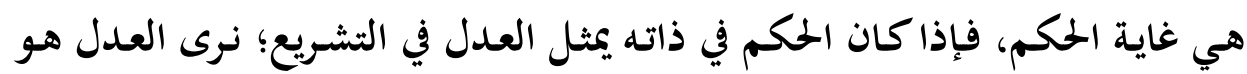

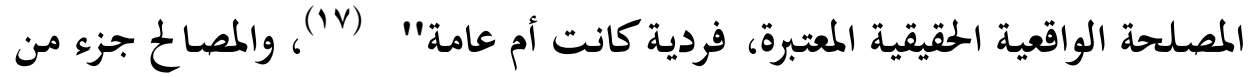

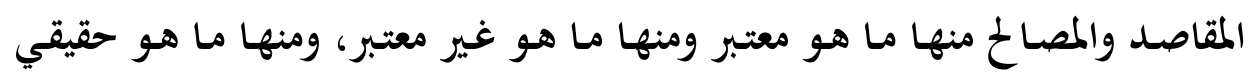

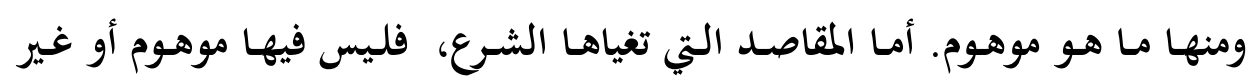
معتبر.

وقـال أمـد الريسـوني: "مقاصـد الشـريعة هي الغـايات التي وضعت الثـريعة

لأجل تحقيقها لمصلحة العباد " (1).

وهذا ما أميل إليه: أن مقاصد الشريعة هي الغايات التي شرعها الله والتي

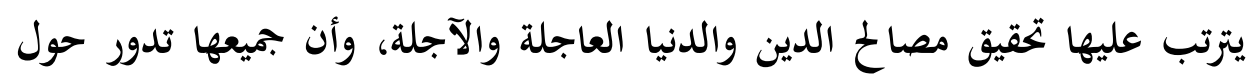
مقصد تحقيق العبودية لله، فهو مقصد المقاصد وغاية الغايات. المطلب الثاني: أهمية علم المقاصد الثرعية:

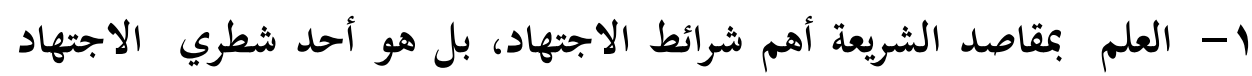

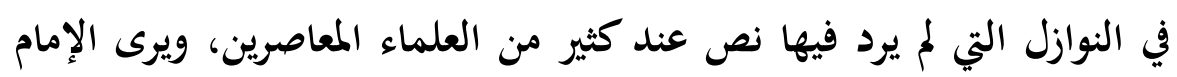

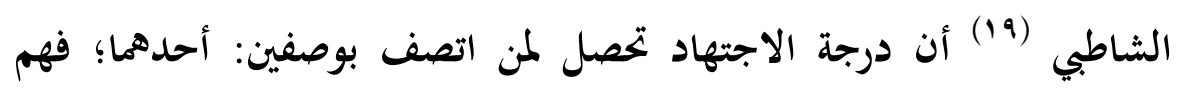

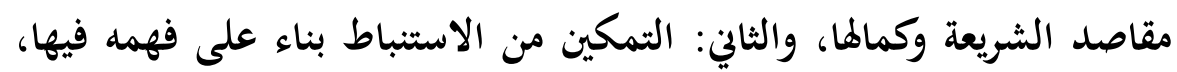

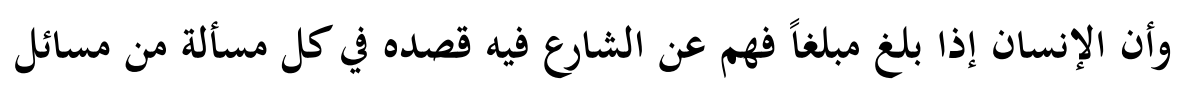

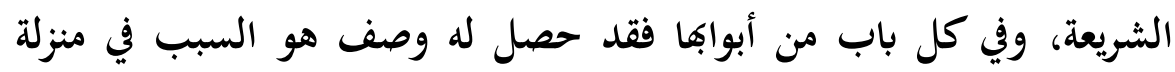
الخليفة للببي - صلى الله عليه وسلم - في التعليم والفتيا والحكم بما أراه الله

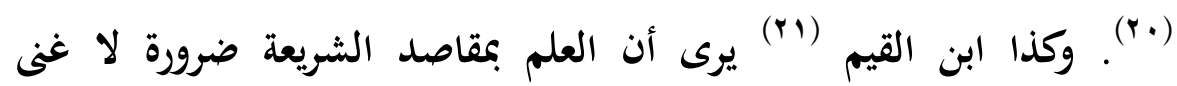

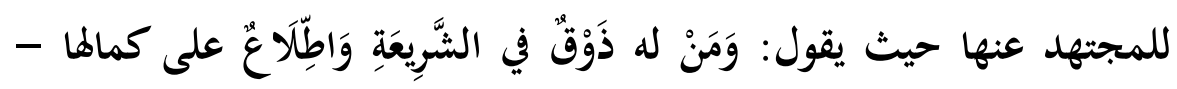

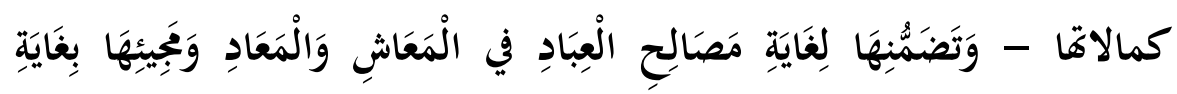




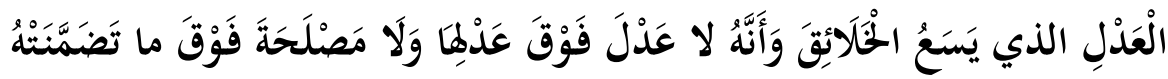

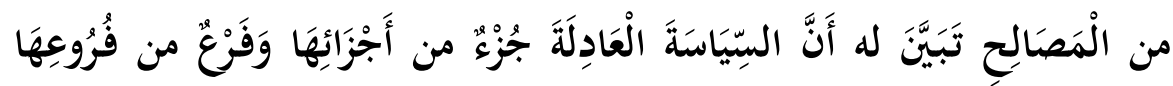

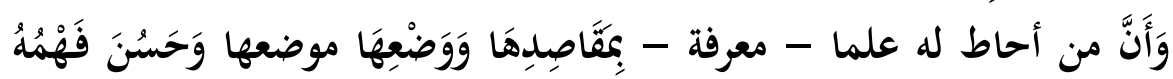

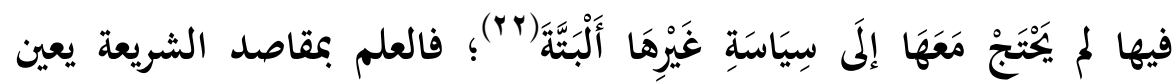
الججتهد على الاجتهاد في القضايا المعاصرة التي لم يرد فيها نص. والقضايا التي تغير حكمها لتغير الظروف المؤثرة على الحكم فيها: كتغير الزمان، والمكان، والأحوال، والعادات...، ولا تقتصر أهمية العلم بالمقاصد على الجانب التنزيلي بتحقيق مناط الأحكام الشرعية وبمعالجة الحكم للواقعة المعالجة الصحيحة، بل يتعداها إلى الجانب التطبيقي أو الاجتهاد التطبيقي. Y - العلم بالمقاصد الشرعية يعين على فهم النصوص الشرعية، ومعرفة أسرارها، وإدراك مصالحها المعتبرة شرعاً، واستنباط الأحكام المترتبة على فقهها، يقول ابن تيمية: فإن الاستدلال بكلام الشارع يتوقف على أن يعرف ثبوت اللفظ

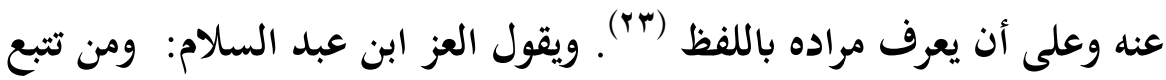
مقاصد الشرع في جلب المصالح ودرء المفاسد حصل له من مجموع ذلك اعتقاد أو عرفان بأن هذه المصلحة لا يجوز إهمالما وأن هذه المفسدة لا يجوز قرباها وإن لم يكن فيها إجماع ولا نص ولا قياس خاص فِإن فهم نفس الشرع يوجب ذلك (צ') ويؤكد ابن عاشور: أن الفقيه بحاجة إلى مقاصد الشريعة في فهم ألفاظ النصوص وإعطاء حكم لفعل أو حادث حدث للناس لا يعرف حكمه فيما لاح للمجتهدين من أدلة الثريعة، ولا له نظير يقاس عليه (ه). ب- الإفادة منها عند التعارض بين الأدلة بدفع هذا التعارض؛ وذلك بالجمع بين الأدلة أو الترجيح بينها، أو التوفيق بين الدليلين؛ بناء على فقه المقاصد الشرعية واستلهام روح التشريع، يقول الغزالي: مقاصد الشريعة قبلة الجُتهدين؛ من توجه 
إلى جهة منها أصاب الحق (َr). . ويستفاد كذلك من فقه المقاصد الشرعية في

التمييز بين صحيح القياس وفاسده(FV).

ع - الإفادة منها في ضبط الفتوى،وحفظ الدين من البدع، ومرجع ذلك كله الجهل بمقاصد الشريعة؛ يقول الشاطبي: "المبتدع من هذه الأمة إنما ضل في أدلتها حيث أخذها مأخذ الهوى والشهوة لا مأخذ الانقياد تحت أحكام الله..... فإذا انضم إلى ذلك الجهل بأصول الشريعة وعدم الاضطلاع بمقاصدها كان الأمر

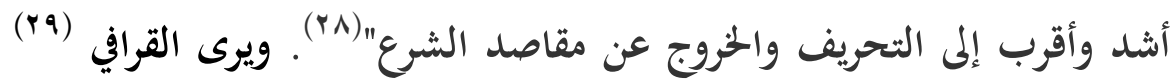
أن التمكن من مقاصد الثريعة وأسرارها، هو السبيل لحفظ الثريعة ودفع شبه

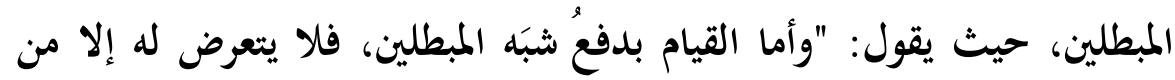
طالع علوم الثريعة وحفظ الكثير منها، وفهم مقاصدها وأحكامها، وأخذ ذلك

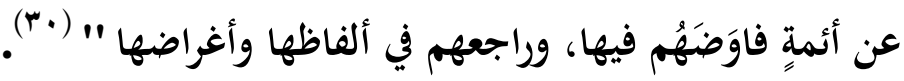
ه- التزام مبدأ الوسطية في التشريع وماية الأمة من مزالق الجمود على المأثور، ومهالك التغريب الممقوت، ووقايتها من مخاطر عزلة الزمان والمكان. يقول الدكتور عبد الجيد النجار: "إن فريقاً من المسلمين حصروا أنفسهم في دائرة الماضي، ووقف بمم الزمان عند اجتهاد المتقدمين؛ إذ طبعت عقولهم على مثالية التفكير أصبح بما النظر في الواقع والسعي في تغيره إلى الأصح لا يكون إلا من خلال المثال السلفي على سبيل الاستنساخ للصور الجزئية لذلك المثال وإجرائها على صورة الواقع لا على سبيل الاستفادة من الفقه الذي تحقق على أساسه المثال السلفي، وانتهى الأمر عند هؤلاء إلى خاصية منهجية تتمثل في الاستدعاء الآلي للمثال السلفي في كل معالجة لحياة الواقع الراهن انصرافاً عن المقتضيات المخصوصة لهذا الواقع (اس). وآخرون انعزلوا عن الماضي وخرجوا عن مفاهيم السلف واستدعوا مفاهيم مستوردة، وأنماط فكرية شاذة من الججتمعات الغربية؛ يريدون أن يسقطوها على واقع المسلمين فكراً وتشريعاً 
وسلوكاً؛ ليصدق عليهم ما رواه أبو سعيد الخدري عن الببي - صلى الله عليه

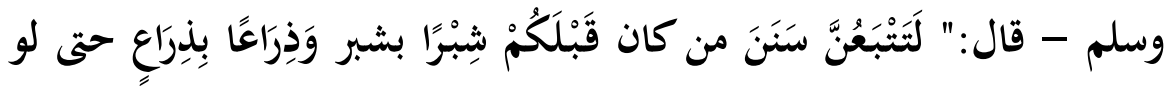

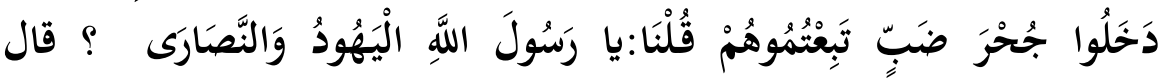

فمن....

فالماديون الذين اقتصروا على إحياء المثال السلفي فقدوا عنصر المعاصرة،

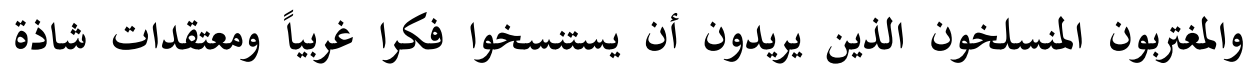
فقدوا عنصر الأصالة. - الة

وبين هذا وذلك فريق ينضبط بالمق ويحكم مقاصد الشريعة وكليات الدين،

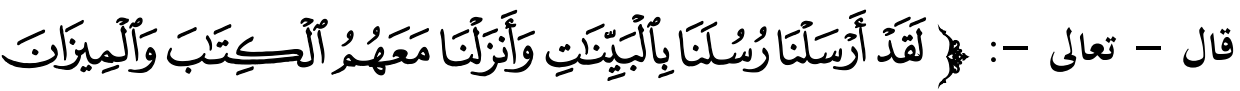

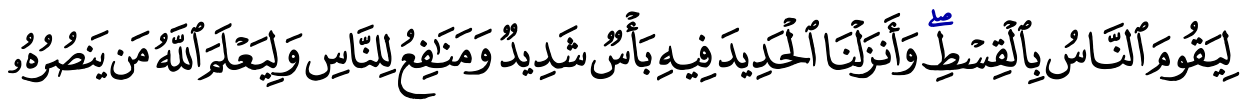

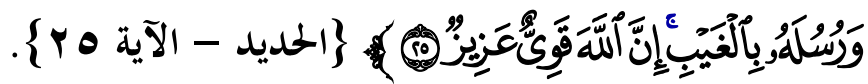
فهؤلاء مجتهدون يجمعون بين فقه النصوص ومقاصدها وبين فقه الواقع. المطلب الثالث: تاريخ نشأة المقاصد الشريعة:

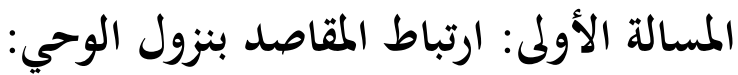
المقاصد الشرعية علم من العلوم الشرعية التي ارتبطت بنزول الوحي وبعثة النبي محمد - صلى الله عليه وسلم -، والمقاصد هي غايات التشريع التي نزل بها

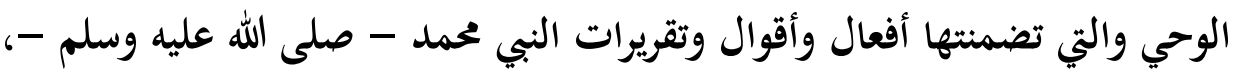

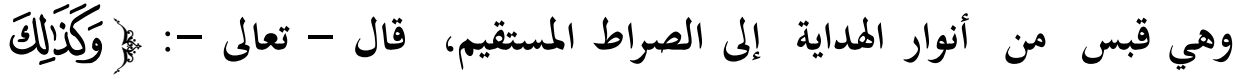

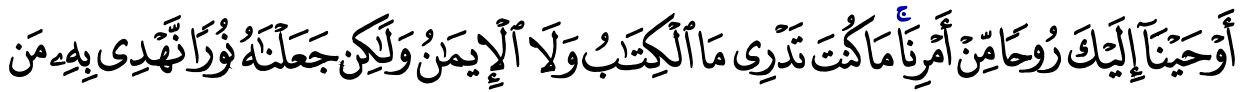

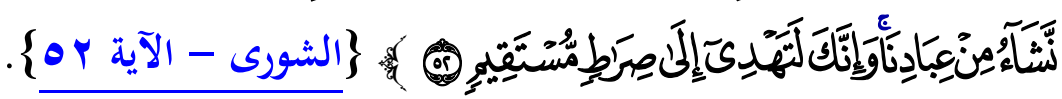
لذا فإن صحابة البي محمد - صلى الله عليه وسلم - تلقوها غضة طرية،

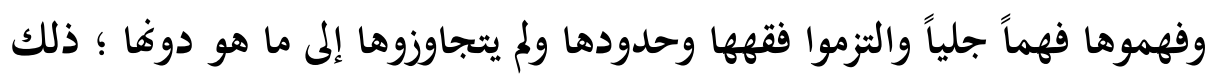


أنها أوضح من أن تخفى على فقهائهم، لفصاحة لساغم فهم أصحاب بيان وبلاغة،

ولملازمة كبار الصحابة- رضوان الله عليهم- - لرسول - صلى الله عليه وسلم فلا يظن أن يشكل عليهم شيء لا يسألون عنه رسول الله - صلى الله عليه وسلم -

والمقاصد الشرعية الكلية القطعية ظاهرة للعنان،أوضح من أن تخفى، ومدارها

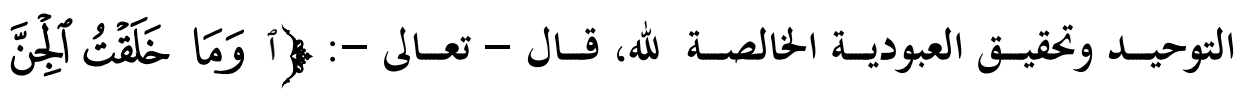

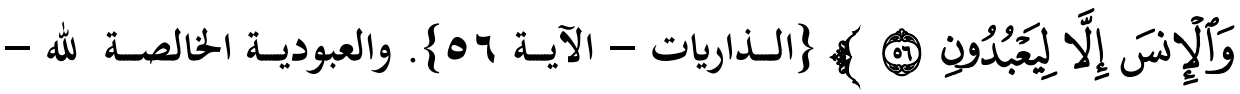
تعالم - مقصد المقاصد، وكل المقاصد تتفرع عنها، وتدور في فلكها، وأعظم المقاصد

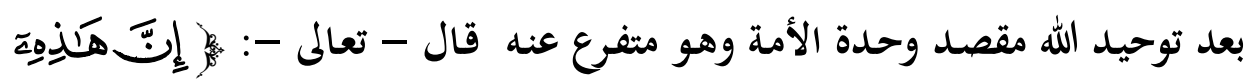

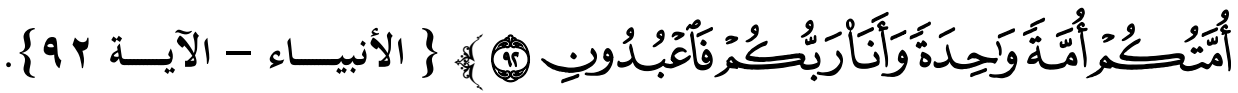
* وهو من المقاصد الكلية القطعية، وكذا مقصد العدل والقسط قال - تعالى -:

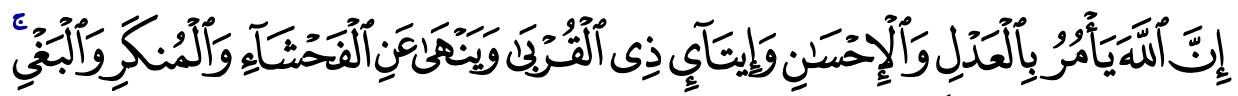

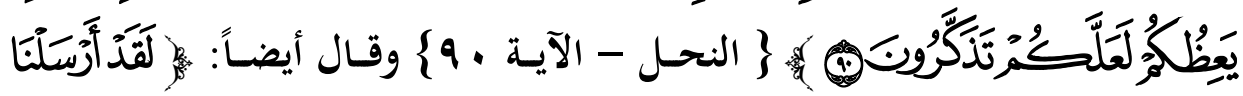

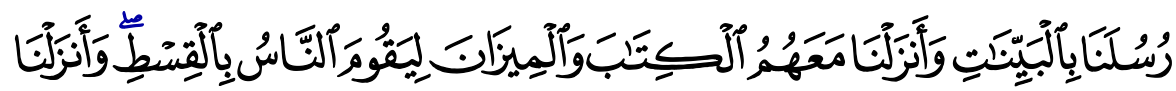

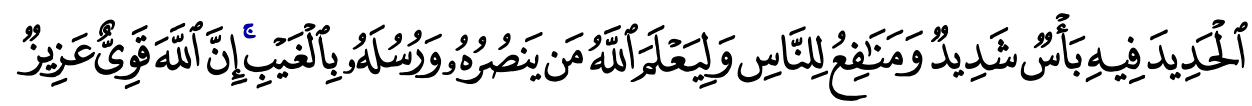

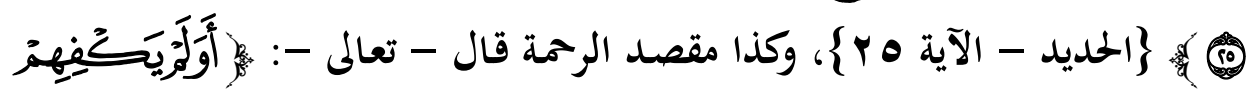

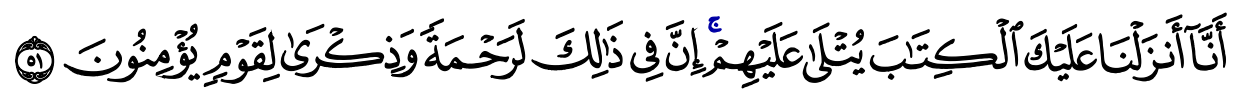

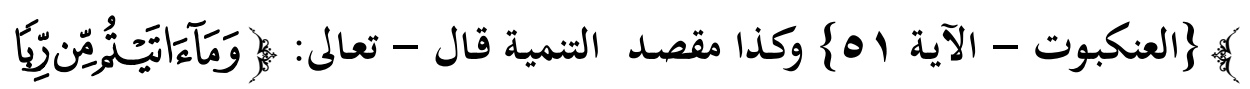

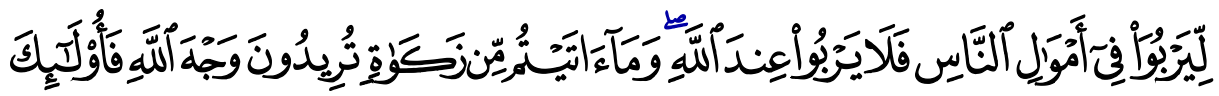

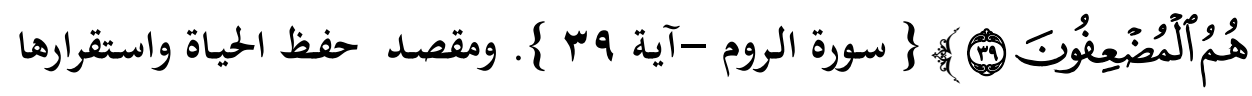

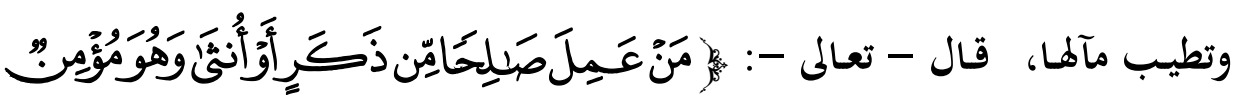




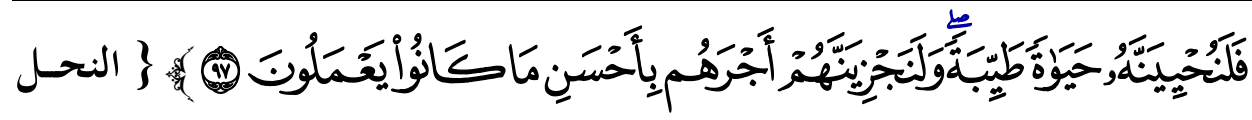

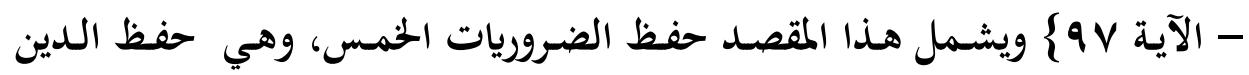
والنفس والعرض والعقل والمال، وهي ضرورات لا تستقيم حياة المرء ولا تطيب إلا بالعافظة عليها ودفع الهـلاك عنها، ولا يمكن لحيـاة حقيقيـة منتظمـة أن تـتم بـدوفا؛ "فبـدون الدين يتحول النـاس إلى هـه ويفقدون حتى إنسانيتهم وكرامتهم ورسـالتهم وسر وجودهم.ثم يأيت الحُسران في الآخرة، وهي أدهى وأمر.

وحفظ النفوس أمره واضح، فإذا أصبحت النفوس عرضة للتلف والهلاك

والاقتتال والججاعات والأوبئة، واستشرى ذلك واستمر مدة من الزمن فإنه يؤدي إلى s)

وحفظ العقول كذلك كحفظ الدين؛ لأن الدين والعقل - على اختلاف الدرجة - هما سبيل الرشاد والسداد، وسبيل التدبر وحسن التصرف. وإذا فقد العقل فقد الدين،ولا دين بلا عقل، فالعقل ضرورة من الناس ينعكس أثرها على أدياغم وأبداغم وأخلاقهم وأرزاقهم. والنسل كذلك؛ لأن النسل والنفس من جنس واحد، إذا فقدت النفوس فهو هلاك فوري مباشر، وإذا فقد النسل أو توقف أو تعثر أو تضاءل، واستمر ذلك، فالمالوك آت ولو بعد حين. أي: الانقراض والتلاشي في البشرية. وهكذا أيضاً يقال في المال، فالمال في جملته أمر لا حياة بدونه، لا الفرد ولا الجماعة، والمال قوام هذه الحياة الدنيا ومحكها؛ فحفظ الأموال - أيضاً- من من

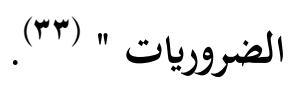
والمتتبع لسيرة النبي - صلى الله عليه وسلم - يبد أنه كان يستلهم مقاصد الشريعة وكليات الدين في تنزيله الأحكام ومعالمته للوقائع، وقد روي عن السيدة عائشة- رضي الله عنها- أكا قالت: قال لي رسول الله - صلى الله عليه وسلم -- ( ) 
لولا حداثة عهد قومك بالكفر لنقضت الكعبة ولجعلتها على أساس إبراهيم فإن

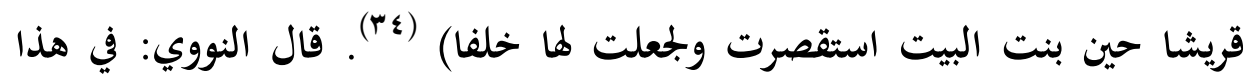

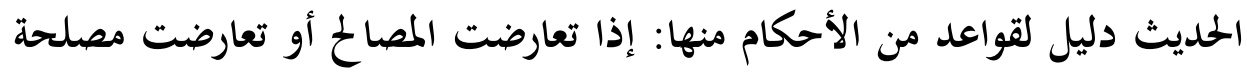

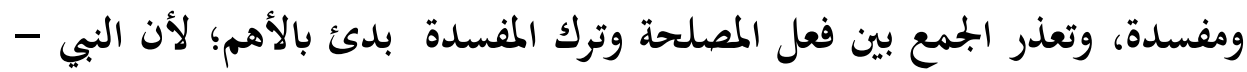

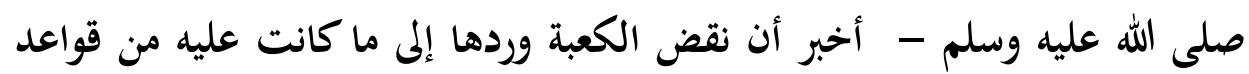
إبراهيم- عليه السلام- مصلحة، ولكن تعارضه مفسده أعظم منه وهي خوف فتئل بعض من أسلم قريبا؛ وذلك لما كانوا يعتقدونه من فضل الكمانه الكعبة فيرون تغييرها عظيما

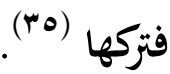

المسألة الثانية: المقاصد في عصر الصحابة- رضوان الله عليهم-:

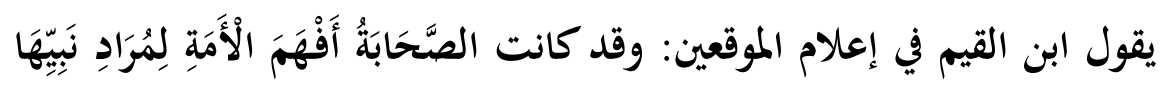

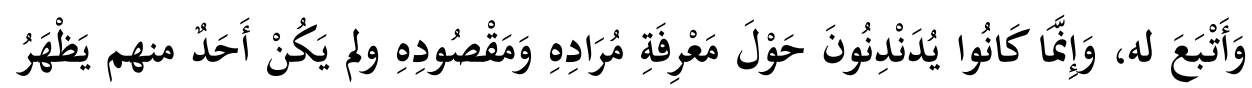

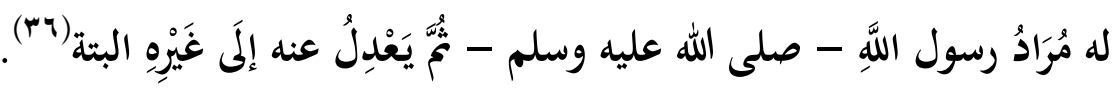

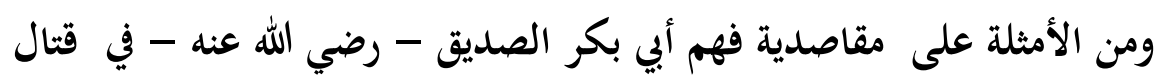

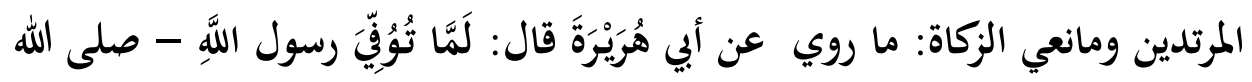

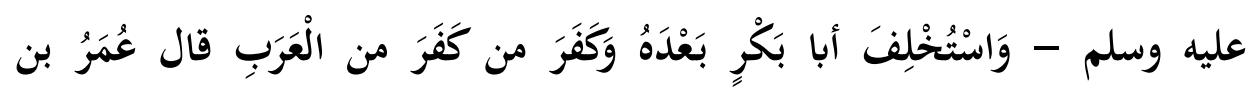

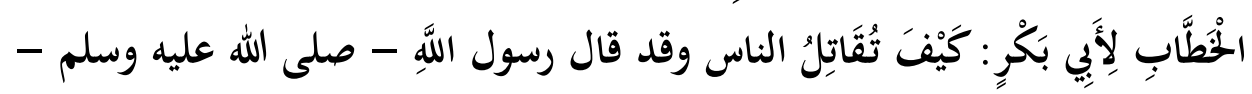

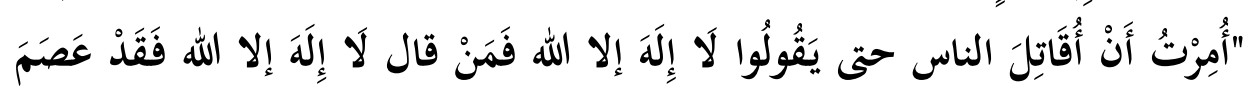

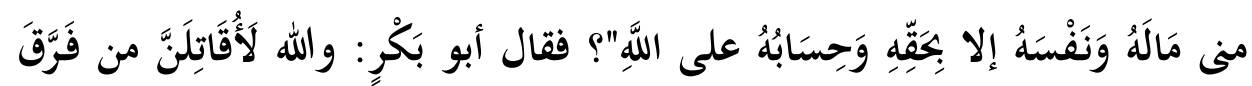

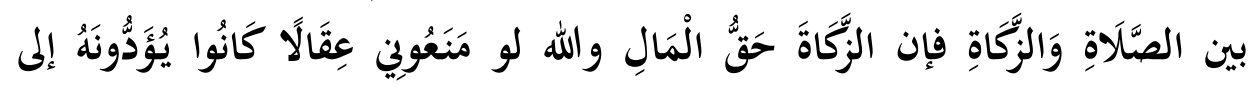

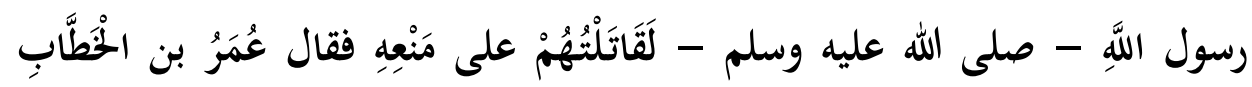

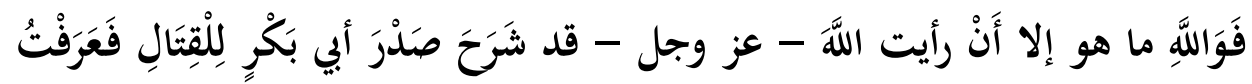

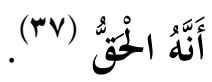


وهذا الحديث دليل على أن عمر - رضي الله عنه- التزم ظاهر النص وأن أبا

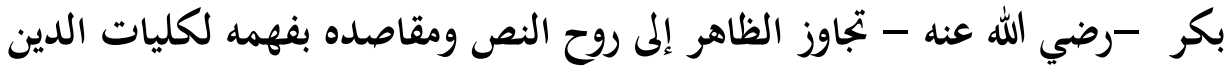
وأركانه وأن المحافظة عليه تكون بحفظ أركانه، وأن من فرط في ركن فقد بقية الأركان،

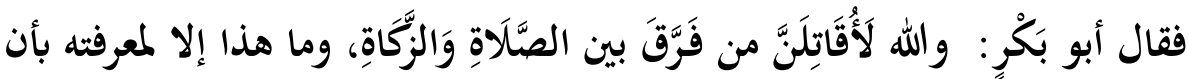
حفظ الدين ضرورة لا غنى عنها، وأن زوال ركن زوال للدين كله.

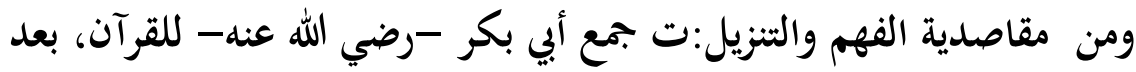

أن استحر القتل بقراء القرآن؛ خشية ذهاب كثير من القرآن، وحفظاً للدين قال -

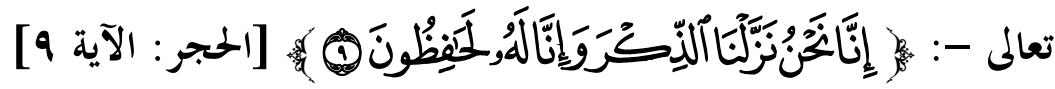

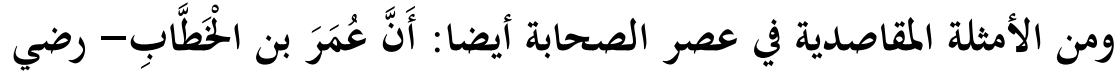

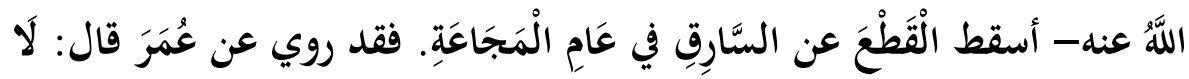
تُقُطَعُعُ الْيَدُ في عِذْةِق وَلَا عَامِ سَنَةِّ. ويعلق ابن القيم على هذا الاجتهاد من عمر - رضي الله عنه- بقوله: وَهَذَا

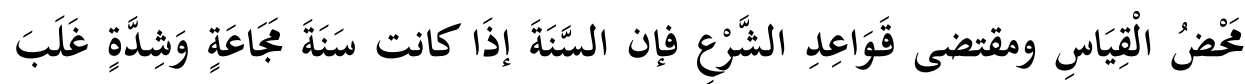

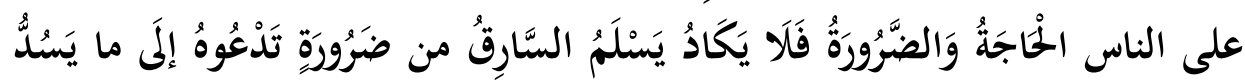

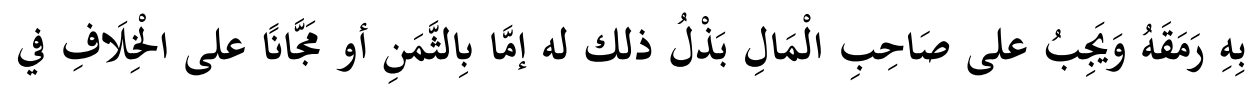

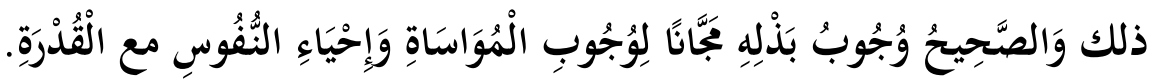
إن إسقاط عمر للحد عام الجماعة إعمال لروح النصوص ومقاصد الشريعة،وليس من العدل معاقبة المضطر مرتين بل العدل أن يسد جوعه، ويدفع عنه إعله اضطراره. المسألة الثالثة: المقاصد في عصر التابعين: لقد كان عصر التابعين امتداداً لعصر الصحابة- رضوان الله عليهم-، فقد

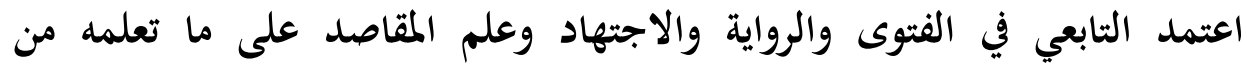


أصحاب النبي - صلى الله عليه وسلم -، وفي هذا العصر بدأ ظهور المدارس

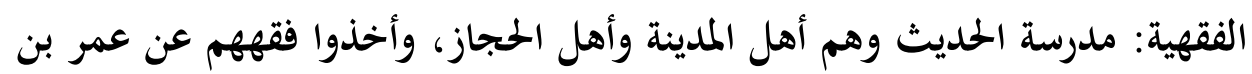

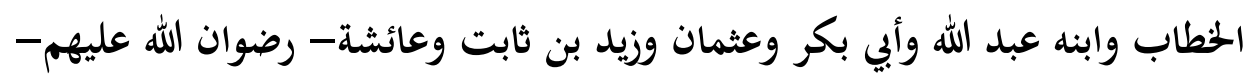

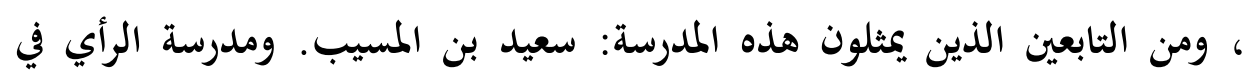

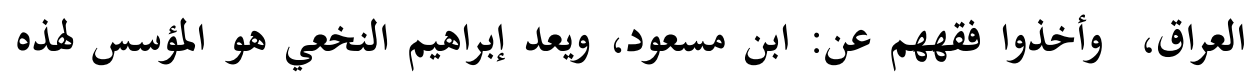

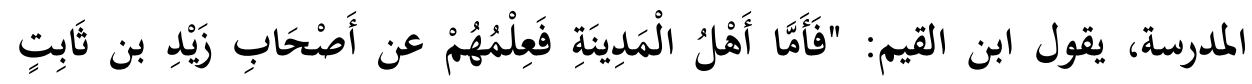

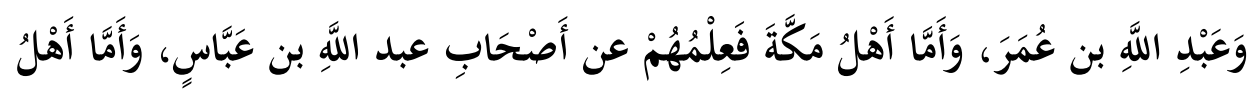

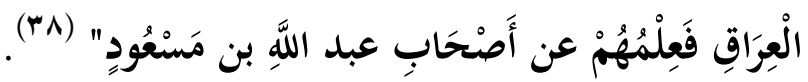

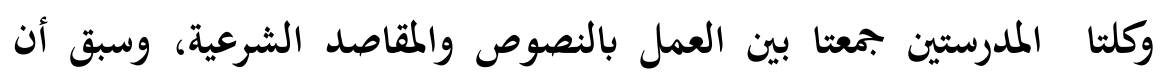

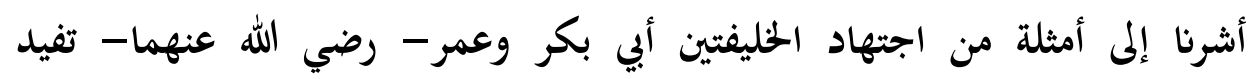

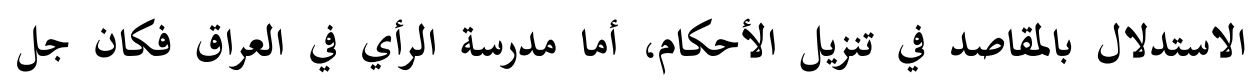

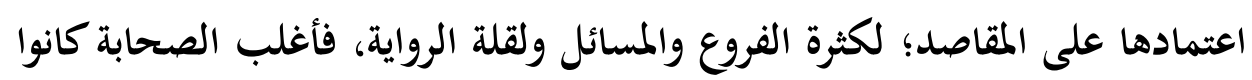

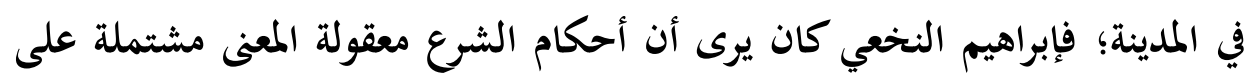

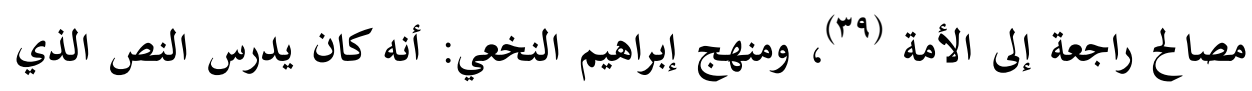

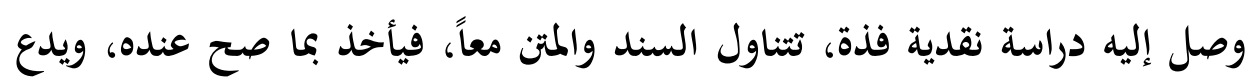

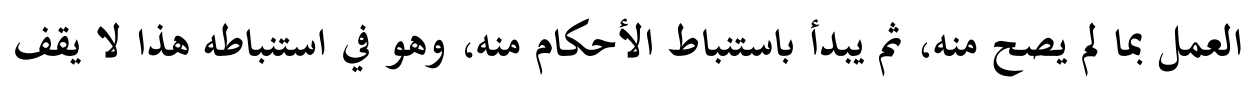

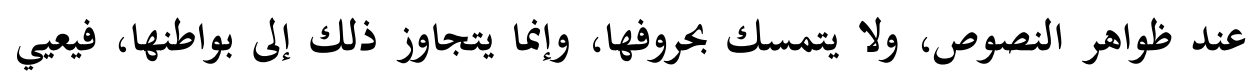

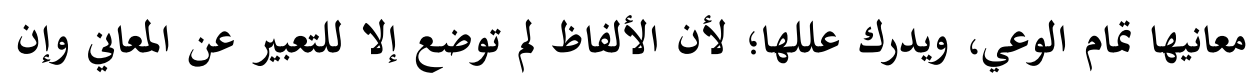

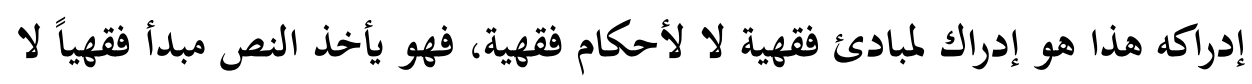
حكما فقهيا شتان بين الاثنين؛ لأن الحكم الفقهي ينطبق على حادثة معينة، والمبدأ

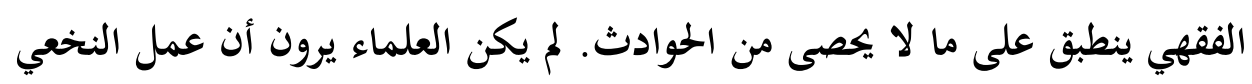

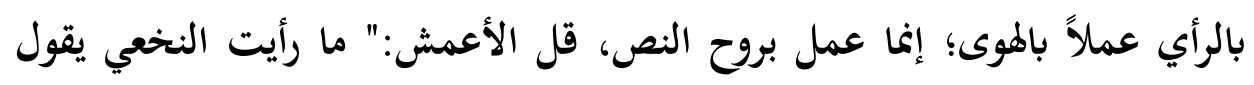

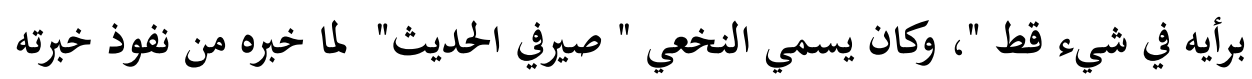


إلى حقيقة المعدن، ولا يغره الظاهر؛ لذا أيضاً كان يحدث بالمعاني؛ لأن العبرة عنده الإهاهية

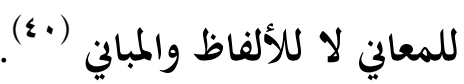

ومن فتاويه: أن المسافر إذا قرأ السجدة يومئ إيماء في سجودها،ومنها: لمس

المرأة بشهوة ينقض الوضوء، ومنها جواز الاشتراط عند الإحرام (1) المسألة الرابعة: تناول الأصوليين لنظرية المقاصد:

لم تأخذ نظرية المقاصد حظها و وكفايتها من الثناول في كتابات الأصوليين خاصة المتقدمين منهم؛ ذلك أغم اعتبروها مما يدخل تحت العلم بالقرآن والسنة والمعالي والحكم المتضمنة فيهما.قال ابن قدامة المقدسي (r٪): " لا بد من إدراك دقائق المقاصد في الكتاب والسنة " (rاء).

كما كان بعضهم يكتفي بالإشارة إليها في مبحث العلة، ولربما كانت تدخل ضمناً في الحديث عن المصلحة أو العرف أو الاستحسان ولا غرو أن المقاصد تتعدى كل هذا لتشمل المعاني، والحكم، والمصالح الظاهرة، والباطنة، في كل حكم كلي، وجزئي، دنيوي، وأخروي، عام، وخاص، فالمقاصد الشرعية هي المدار الذي تدور عليه الأحكام، والأدلة النصية والعقلية هي التي تتوخى المقاصد وتمدف إليها وما تغير الأحكام بتغير الأعراف، والزمان، والمكان إلا مظهر من مظاهر دوران الأدلة في

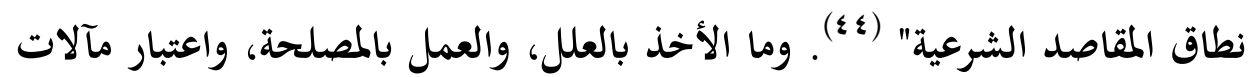
الأفعال إلا تحقيقاً لمقاصد شرعية. يقول إمام الحرمين الجويني (0) ت ل ع \& هـ:" ومن لم يتفطن لوقوع المقاصد في الأوامر والنواهي فليس على بصيرة في وضع الثريعة" († ؛).

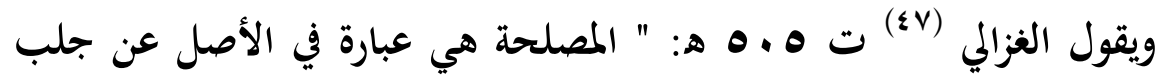

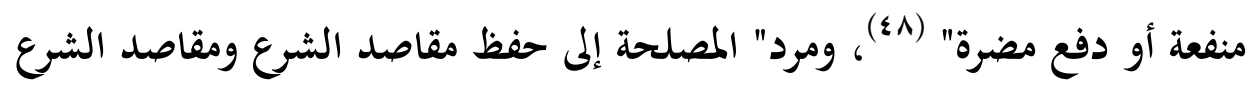
تعرف بالكتاب والسنة والإمماع فكل مصلحة لا ترجع إلى حفظ مقصود فهم من 
الكتاب والسنة والإجماع وكانت من المصالح الغريبة التي لا تلائم تصرفات الشرع

فهي باطلة مطرحة" (ه §).

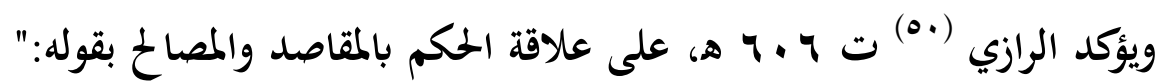

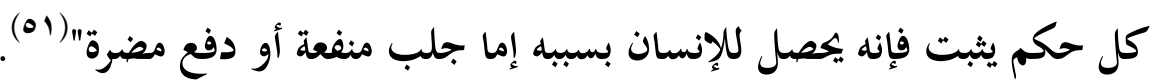

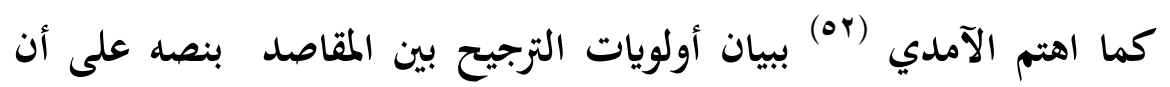

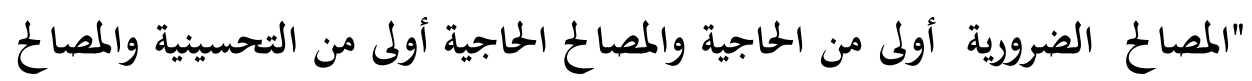

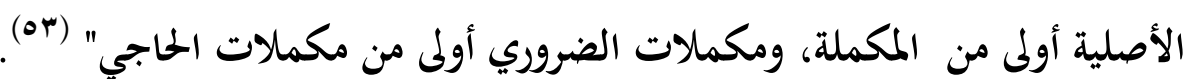

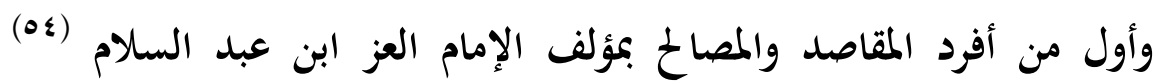

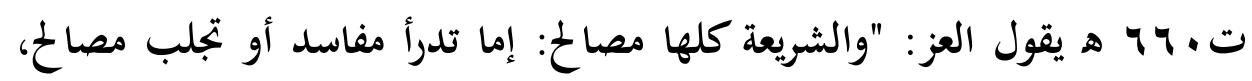

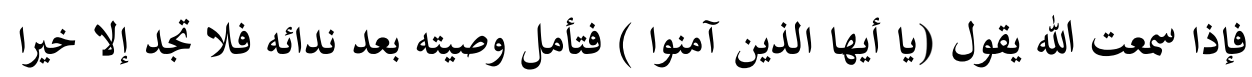

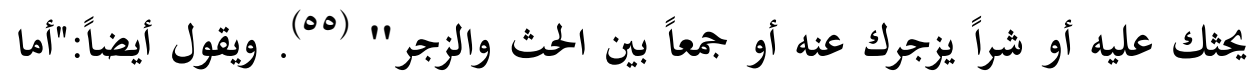

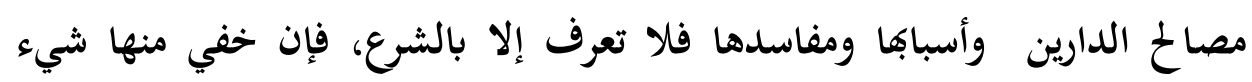
طلب من أدلة الشرع، وهي الكتاب والسنة والإجماع والقياس المعتبر والاستدلال

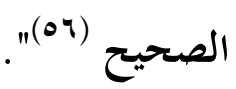
أما القرافي ت ع \ح هـ فيقول عنه ابن عاشور:" إنه من الأفذاذ في علم

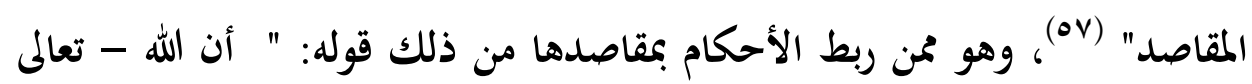

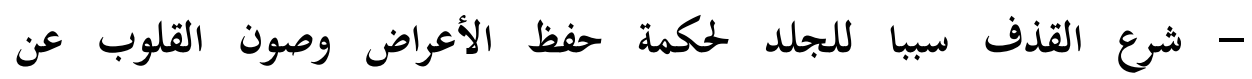

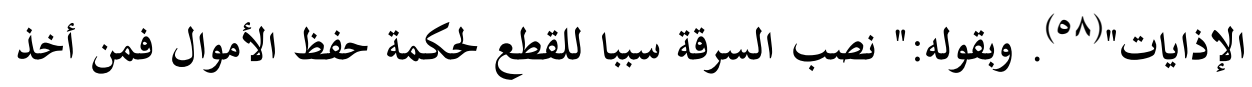

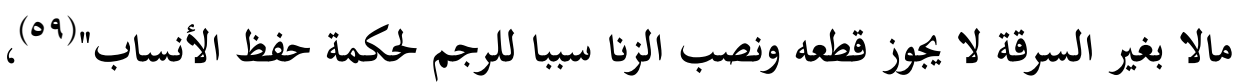

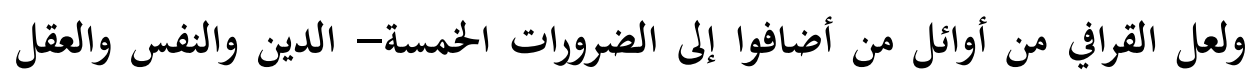

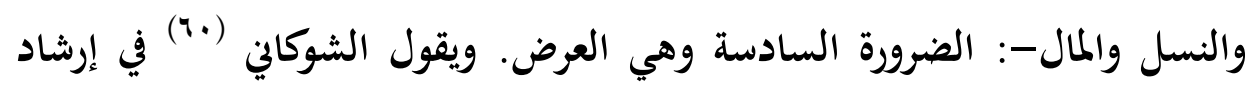
الفحول:" وقد زاد بعض المتأخرين سادسا وهو حفظ الأعراض فإِن عادة العقلاء

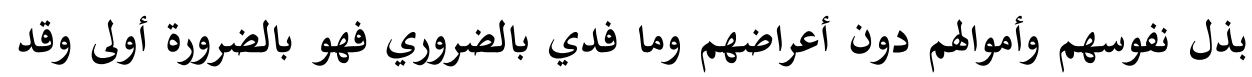




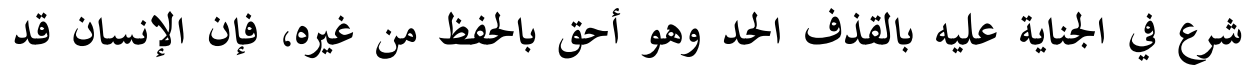

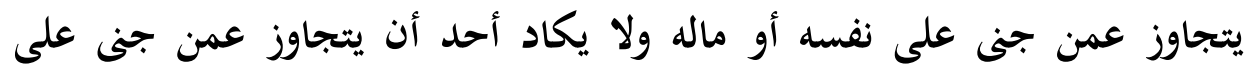
عرضه" (1)

وابن تيمية ت ل VYA هـ، فقد أكثر من ذكر المقاصد باعتبارها أساس التشريع

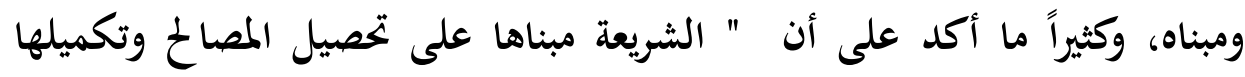
وتعطيل المفاسد وتقليلها بحسب الإمكان ومعرفة خير الحيرين وشر الشرين حتى يقدم

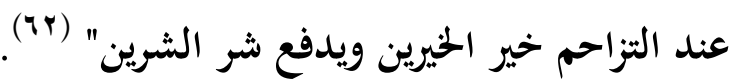

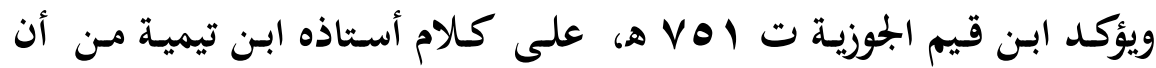

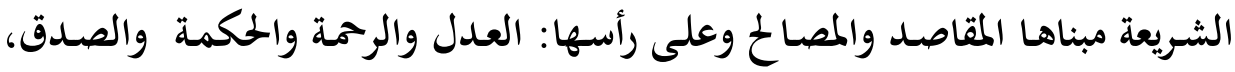

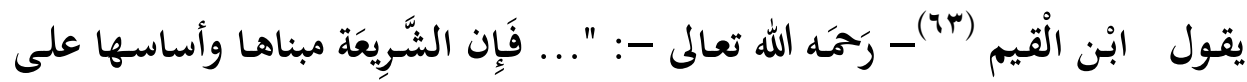

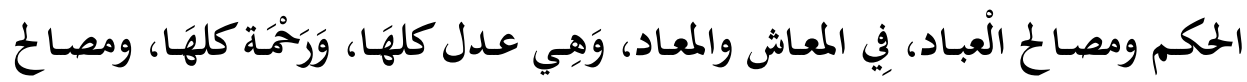

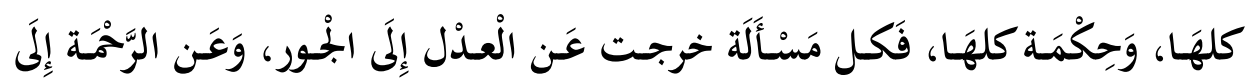

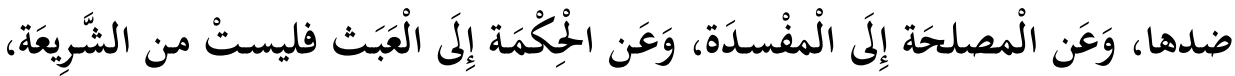

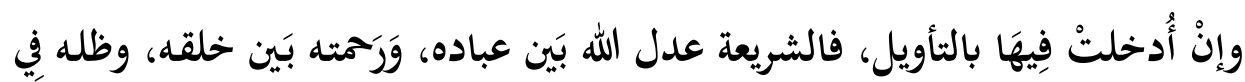

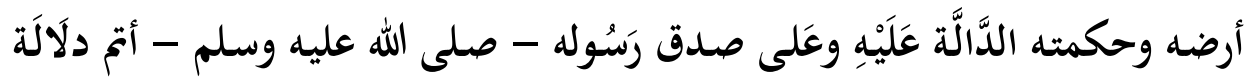

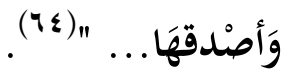

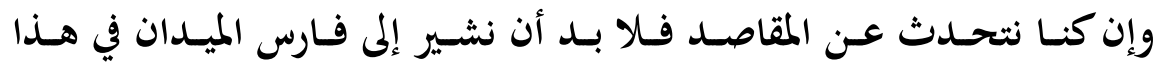

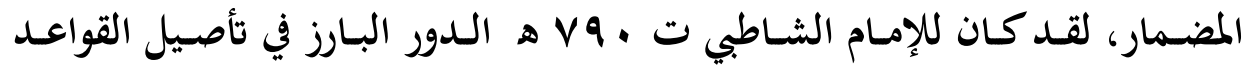

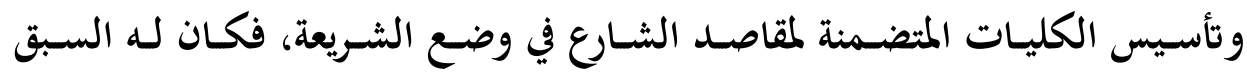
والفضل في تجديد وتنظير وصياغة نظرية المقاصد في كتابه الموافقات، وهو من أعظم

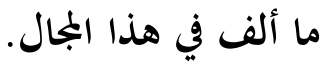
ويـرى الإمـام الثـاطبي: أن درجـة الاجتهـاد تحصـل لمـن اتصـف بوصـفين: أحدهما؛فهم مقاصد الشريعة وكمالها، والثاني: التمكن من الاستنباط بناء على فهمه الإنها 
فيها. وأن الإنسان إذا بلغ مبلغاً فهم عن الشارع فيه قصده في كل مسألة من مسائل

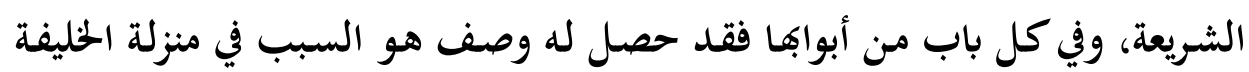

للببي - صلى الله عليه وسلم - في التعليم والفتيا والحكم بما أراه الله (10).

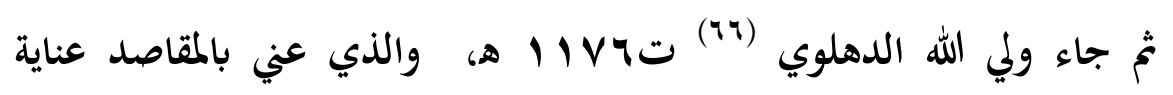

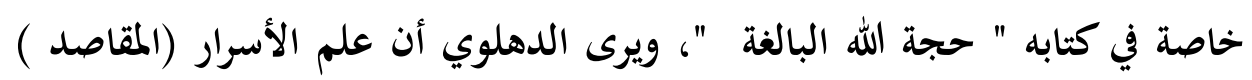

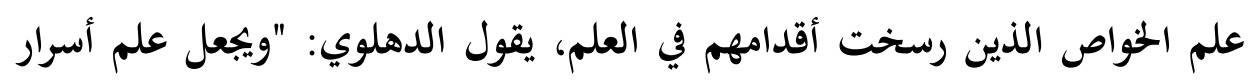

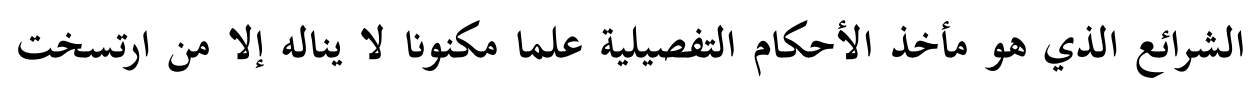

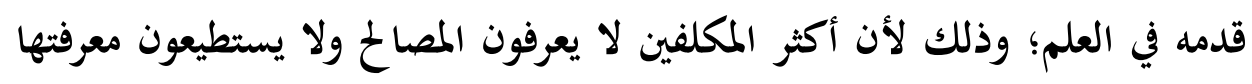
إلا إذا ضبطت بالضوابط..." (TV).

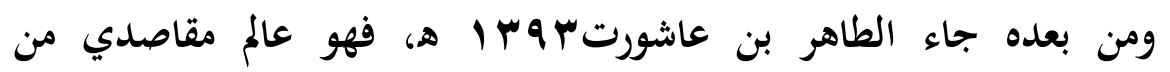

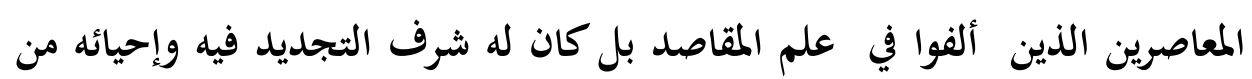

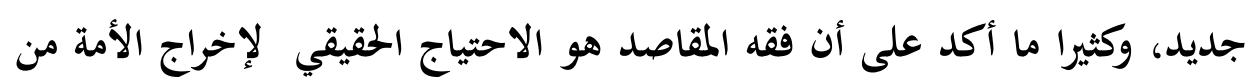

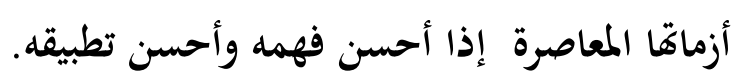
ثم توالت الكتابات من بعده: كعلال الفاسي، والدكتور أحمد الريسوين،

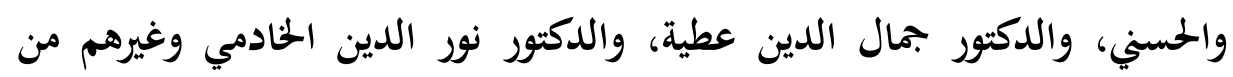
العلماء. المطلب الرابع: أقسام مقاصد الشريعة:

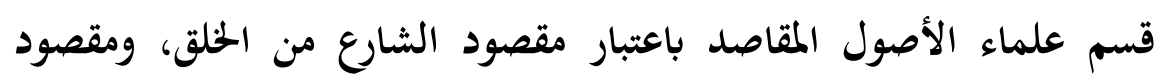

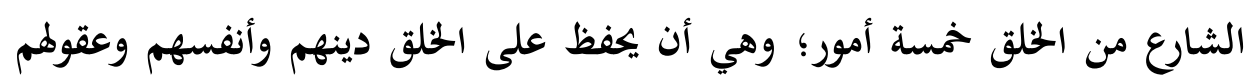

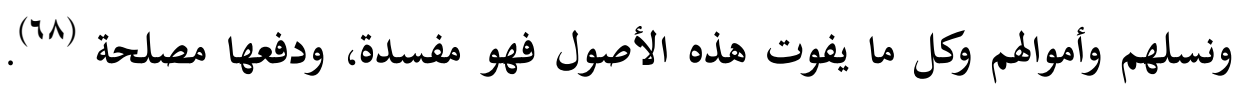

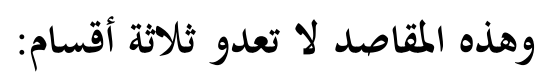


الأول: أن تكون ضرورية، والثاني: أن تكون حاجية، والثالث: أن تكون

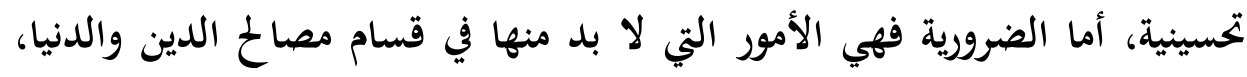

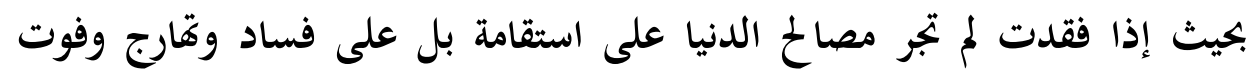

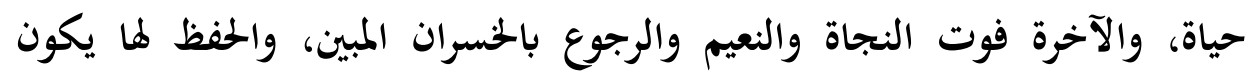

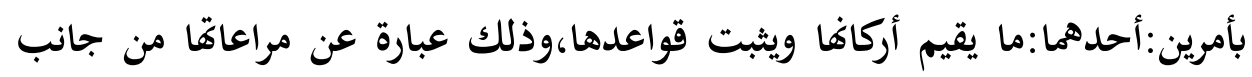

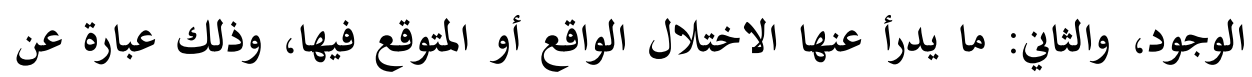
مراعاتما من جانب العدم (79) - (79)

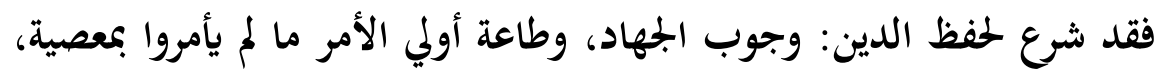
ودرأ عنهم الخلل بقتل المبتدع والحائن.

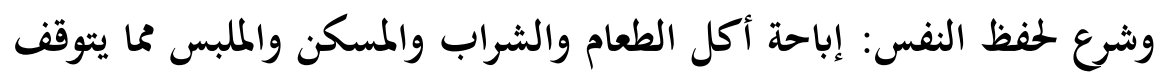
عليه بقاء الحياة ودرأ عنه الخلل باييجاب القصاص أو الدية الدية.

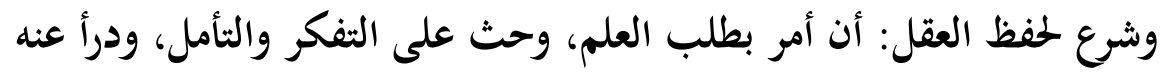
الحخل بإيجابه حدا شرب الحمر. وشرع لحفظ النسل: الزواج وأحكامه، ودرأ عنه الحلل بإيجاب حد الزبا.

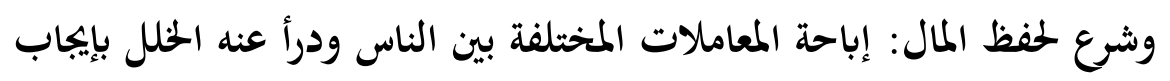
حد السرقة وحد الحرابة.

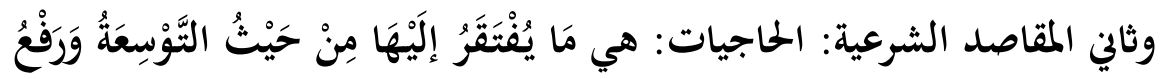

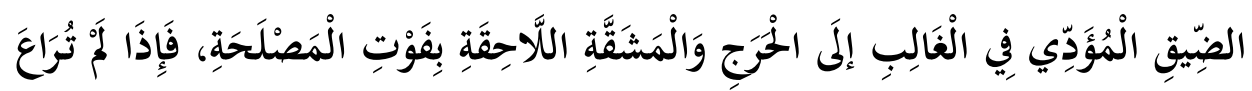

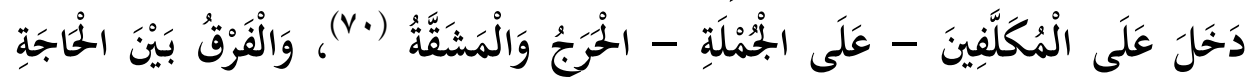

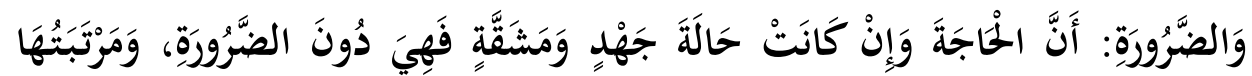

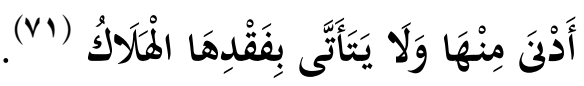
ومثال عليها الرخص المخففة وذلك بدفع المثقة بسبب المرض والهف والسفر،وإباحة عقود القراض والمساقاة السلم. 
وثالث المقاصد الشرعية:التحسينات: هيَ الْأَخْذُ بِمَا يَلِيقُ مِنْ مَحَاسِنِ الْعَادَاتِ

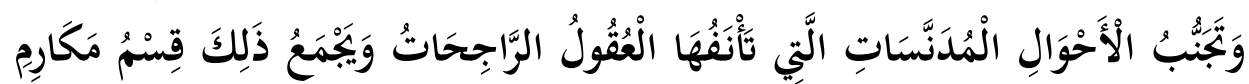

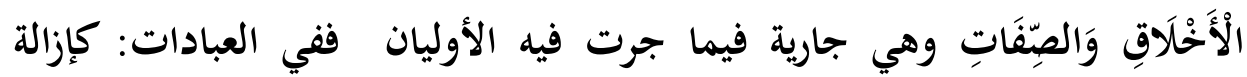
النجاسة وبالجملة الطهارات كلها وستر العورة وأخذ الزينة والتقرب بنوافل الحخيرات من الصدقات والقربات وأشباه ذلك وفي العادات: كآداب الأكل والشرب ومجانبة الماككل النجاسات والمشارب المستخبثات والإسراف والإقتار في المتناولات، وفي

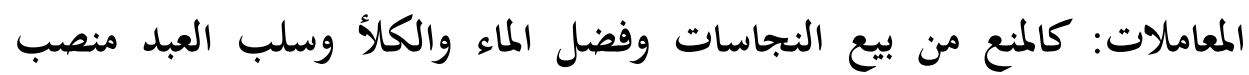
الشهادة والإمامة (VY)

ومن الأصوليين من قسم المقاصد بحسب العموم إلى:

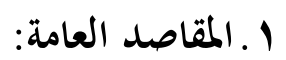

أكد الشاطبي على أن المصالح الكلية "المقاصد العامة " مطردة عامة المامل

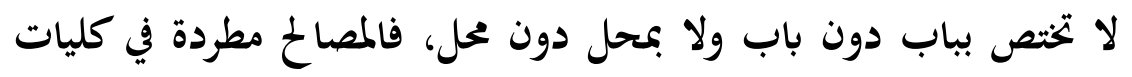
الشريعة وجزئياتا، حيث قال في الموافقات: لما انبنت الشريعة على قصد المحافظة على المراتب الثلاث من الضروريات، والحاجيات والتحسينات

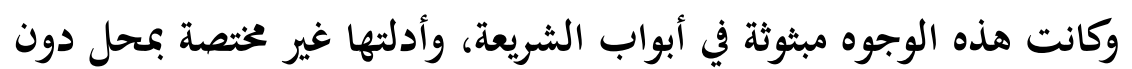
محل ولا بباب دون باب ولا بقاعدة دون قاعدة كان النظر الشرعي فيها

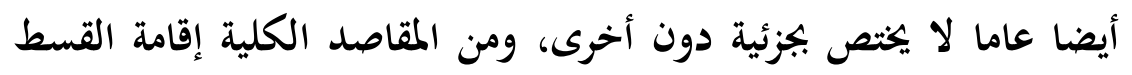

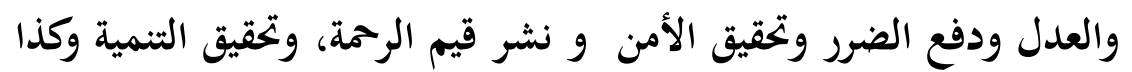
الحرية.

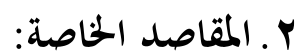
وهي المثعلقة بمجال خاص من مجالات التشريع: كمقاصد الشريعة في

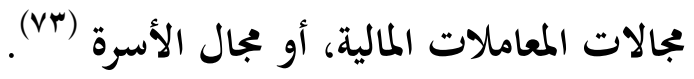

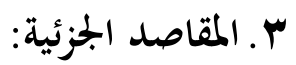


(العدد Vᄉ)

جحلة الدراسات الإسلامية والبحوث الأكاديمية

وهي كل حكم على حدته، من أحكام الشريعة، من إيجاب أو ندب

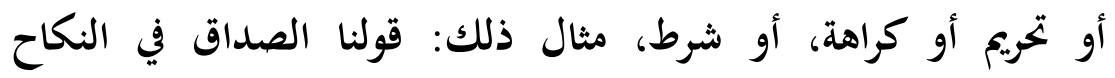

مقصوده: إحداث المودة بين الزوج والزوجة، والإشهاد مقصوده: تثبيت التهات

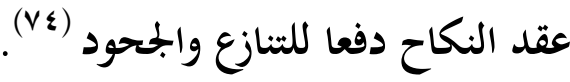

$-0 \vee \leqslant-$ 


\section{المبحث الثاين}

مقاصد الثريعة في الزكاة

شرع الله - عز وجل - الشرائع لمقاصد عظيمة وغايات سامية؛ لتتحقق بها المصالح الدنيوية والأخروية على السواء، ولضبط الأعمال والسلوكيات التي تحفظ حقوق الأفراد، وتراعي مصالح الجماعات دون إفراط ولا تفريط. ولما كانت الزكاة هي العبادة المالية الاجتماعية؛ فإن المقصود في الزكاة أمور

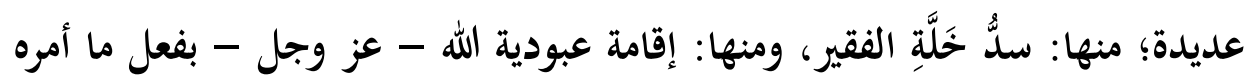
بله، ومنها: شكر نعمته عليه في المال، ومنها: إحراز المال وحفظُُ بإخراج هذا المقدار منه، ومنها: المواساة بجذا المقدار لما علم الله فيه من مصلحة رب المال ومصلحة الآخذ، ومنها: التعبد بالوقوف عند حدود الله، وألا ينقص منها ولا يغير (Vo) ولا شك في أن العبودية الحالصة لله هي مقصد المقاصد وغاية الغايات، وكل المقاصد العامة والخاصة، الكلية والجزئية تدور في فلكها. وقد أشار الشاطبي إلى هذا المعنى في الموافقات: " المقصد شرعي من وضع الثريعة إخراج المكلف عن داعية هواه حتى يكون عبدا لله اختيارا كما هو عبد لله اضطرارا، وأن الحكمة من إرسال الرسل تحقيق

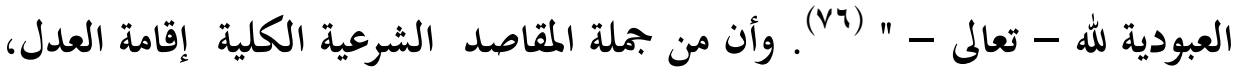
ودفع الظلم، وتحقيق التنمية، ودفع النقص والهلاك، وتحقيق الطهارة، ودفع الحبائث والرذائل، وتحقيق الحرية، ودفع العبودية وتحقيق القوة والتمكين، ودفع الضعف والاستعباد وتحقيق الرحمة ودفع القسوة.

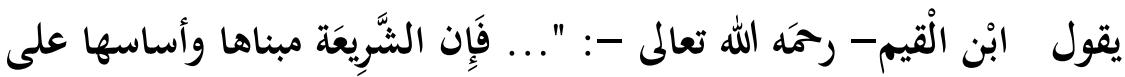
الحكم ومصالح الْعباد، فِي المعاش والمعاد، وَهِي عدل كلهَا، وَرَمْمَة كلهَها، ومصالح

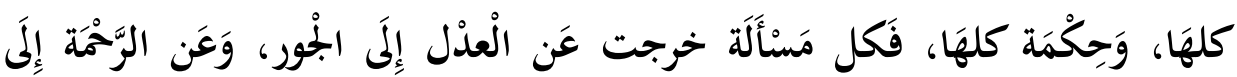

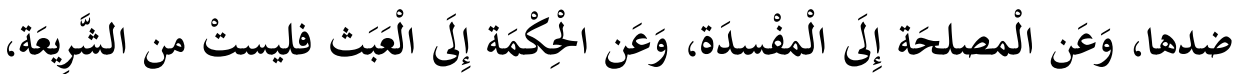


وإنْ أُدخلتْ فِيهَا بالتأويل، فالشريعة عدل الله بَين عباده، وَرَمَته بَين خلقه، وظله فِي

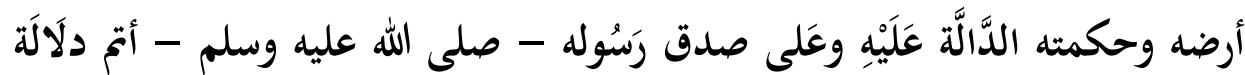

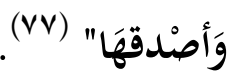

المطلب الأول: مقصد تحقيق العبودية(VN) الخالصة لله وتحرير الإنسان من عبودية غير الله ودفع الثرك بكل صوره وأنواعه:

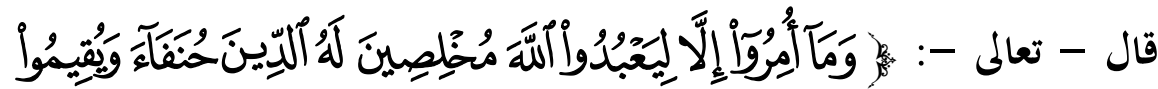

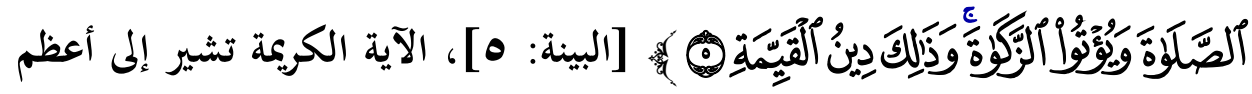
المقامات التي يبلغها الإنسان وهو مقام العبودية، وركني العبودية، وهما: الإخلاص

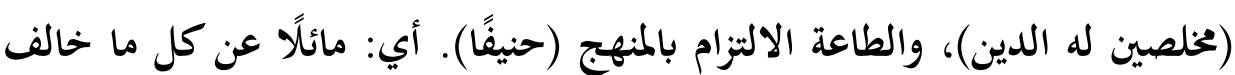
شرع الله وقصده.

قال الثَّاطبي: 》قصد الشارع من المكلف أن يكون قصده في العمل موافقًا

$$
\text { لقصده في التشريع《(V9) }
$$

لقد فاضل الله بين عباده في مقامات العبودية، وجعل على كل أحد عبوديته بحسب ما حباه الله به من ملكات وخصه من مواهب، فالحاكم عبوديته في إقامة شرع الله وممل الناس عليه، والعالم عبوديته في نشر العلم، والغني عبوديته في أداء الحقوق التي في ماله، خاصة تلك التي فرضها الله عليه.

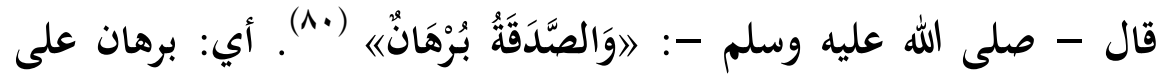
صدق عبوديته لله والذي ينتفي معه عبودية غير الله. ذلك أن عبوديته لله تعني تحرير الفرد من عبودية غير الله.

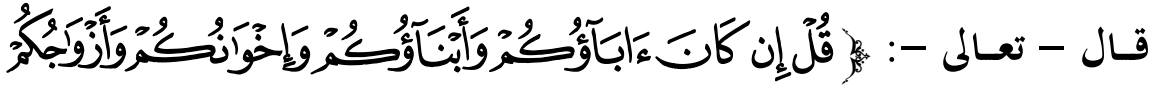

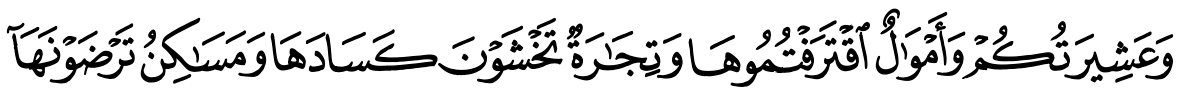




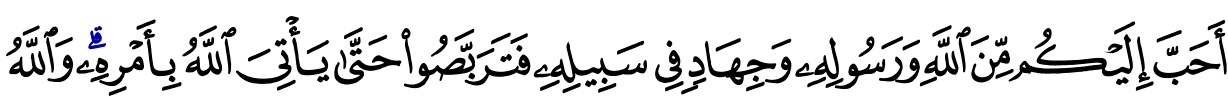

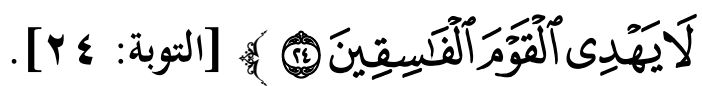

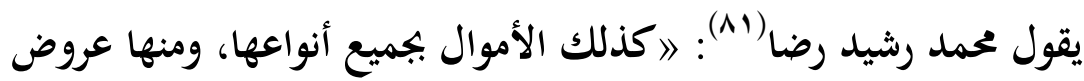
التجارة التي يرجى رواجها ويخشى كسادها - كلها من جوده وعطائه وتسخيره وحبها يجب أن يكون دون حبه؛ بل هو دون ما تقدمه من الحب، وإن فئن فئن بهادها أكثر

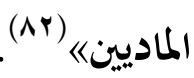

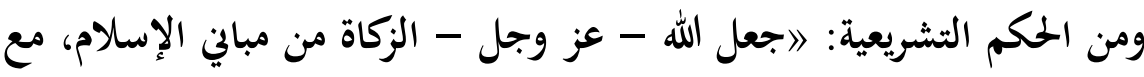

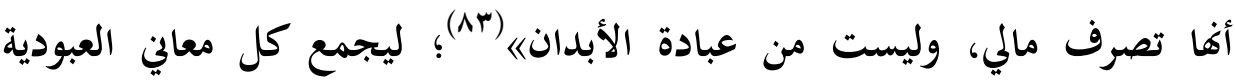

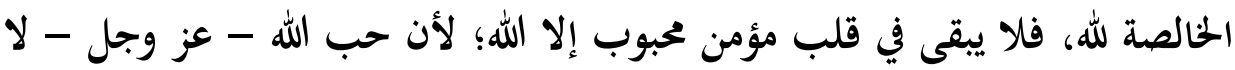

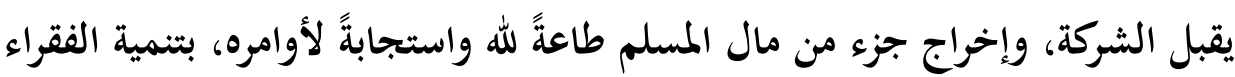

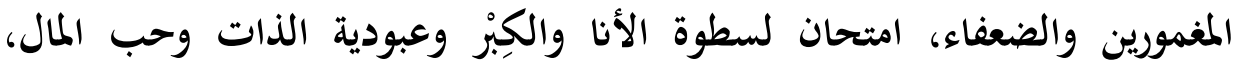
وتجريد النفس عن عبودية كل ما سوى الله. والزكاة كذلك إنما هي تحرير للفقير من أسر الذل مالد والحاجة والاستعباد الاجتماعي، وهي تحمي الفقراء من تحكم أصحاب المال والنفوذ، وهو ما أكده إعلان (قُينا) الذي اعتمد في المؤتمر العالمي لحقوق الإنسان الذي عقد الذهاب في عام

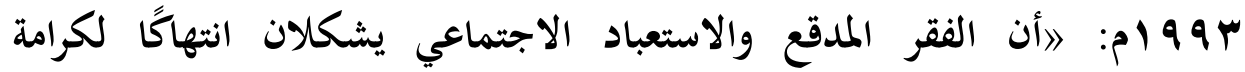
الإنسان《) (A) والإسلام ينظر إلى المادة كوسيلة للعبادة، ويقرر القواعد الفطريـة التي تحرر الإنسان من العبودية للغير بما تحققه له من استقلال مادي يغنيه عن ذل السؤال

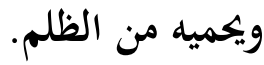

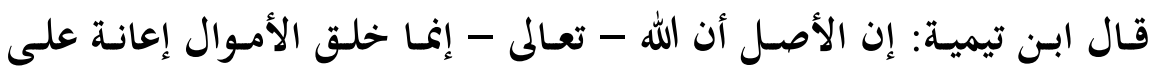
عبادته؛ لأنه خلق الخلق لعبادته (^ه). 


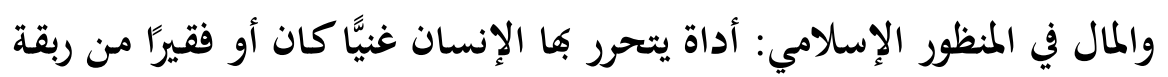

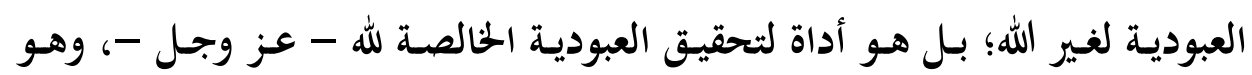

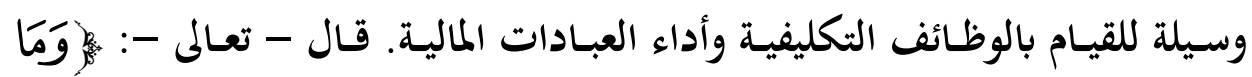

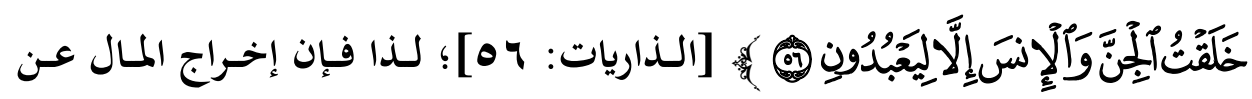

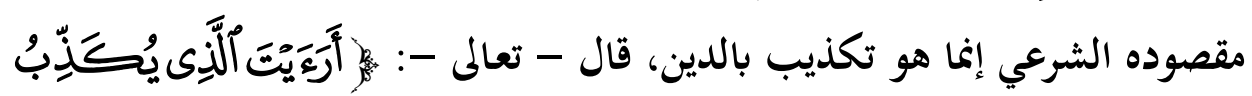

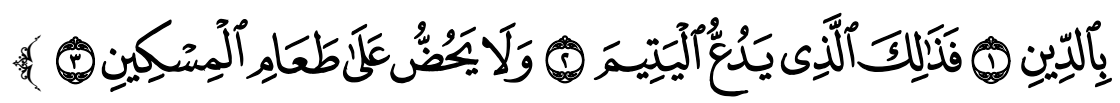

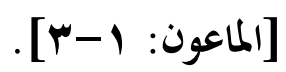

ولما كانت الزكاة دليلاً على صدق العبودية لله - عز وجل - فإِ فإن تعطيلها

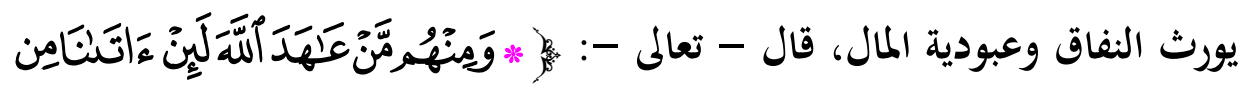

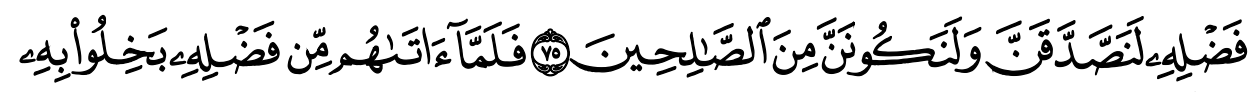

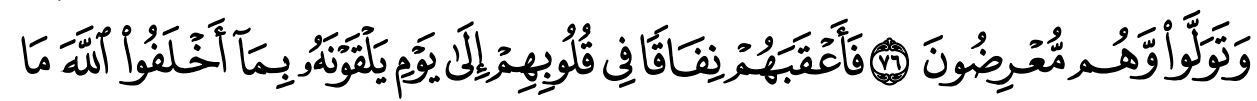

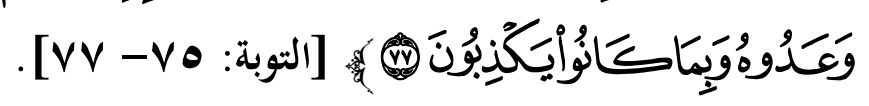

فـأعقبهم. أي: صسير عاقبـة أمرهم النفـاق، والضسمير المستستر في أعقبهم فيسه

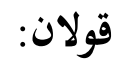

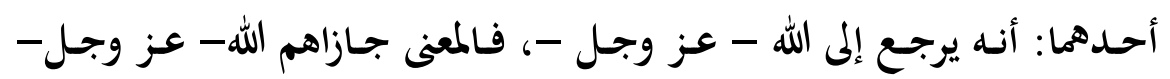
بالنفاق، وهذا قول ابن عباس ومجاهد.

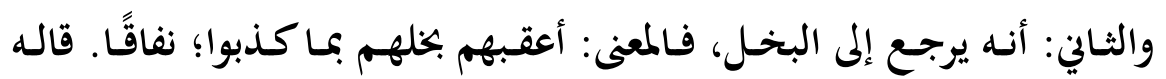

الحسن (^)

ومقصــد إخـاص العبودية، وصـدق الثوجـه إلى الله مقصـد المقاصـد الشـرعية

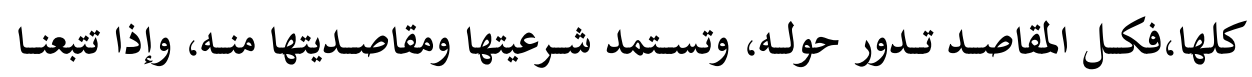
المقاصد الشرعية كلها نجد أفها تتغيا التوحيد وإخلاص التوجهه لله، ومن المقاصديد

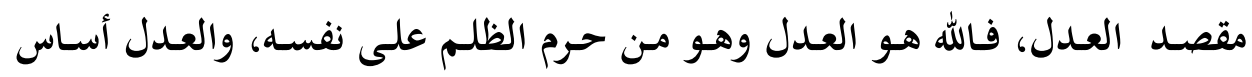


الكونين: المنظور والمقروء؛ لذا فإن العدل مقصد شرعي وزكوي، قال - تعالى - : إ.

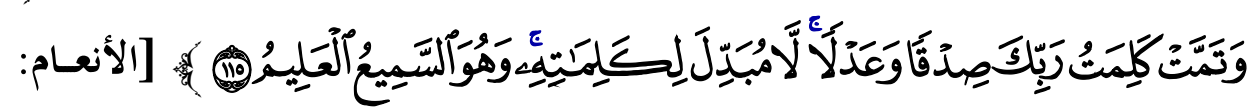

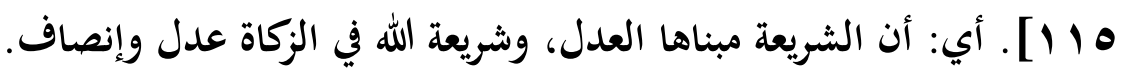

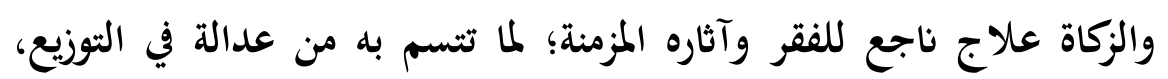

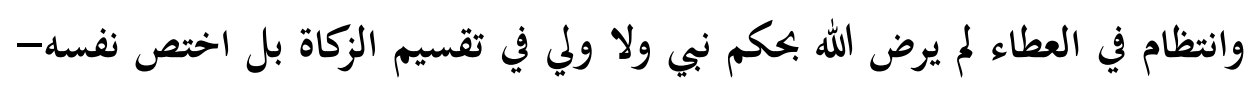

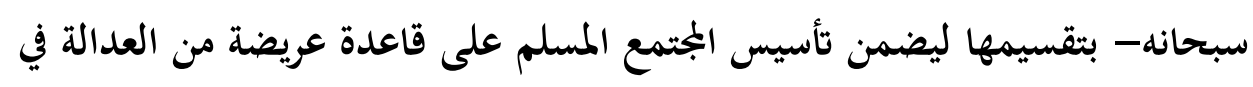

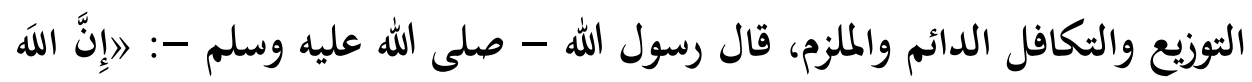

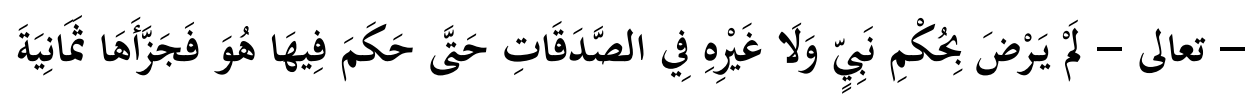

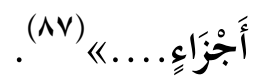
والتنمية من مقاصد الزكاة، وصدق التوجه اللى الله هو مرتكز التنمية الزكوية

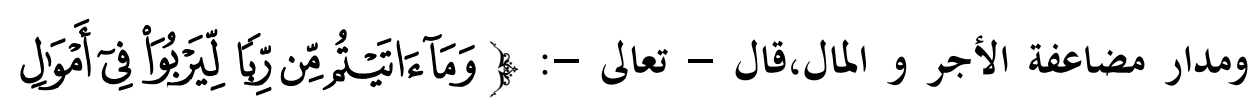

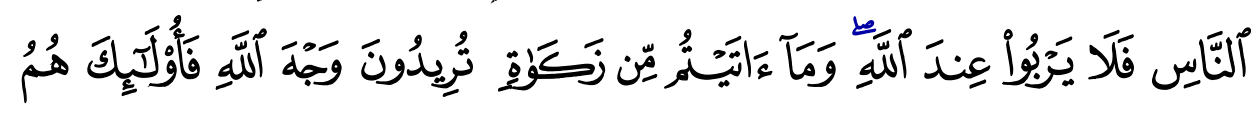

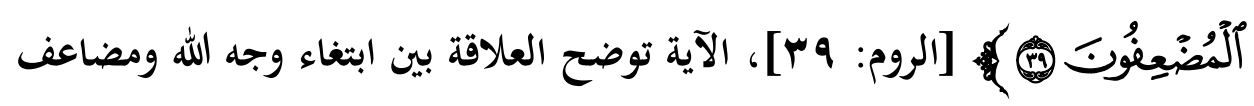

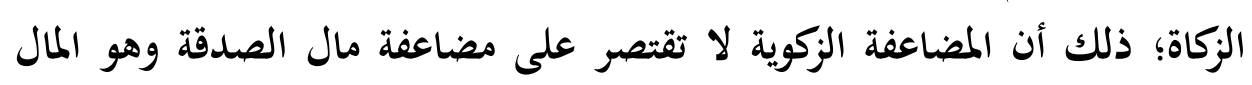

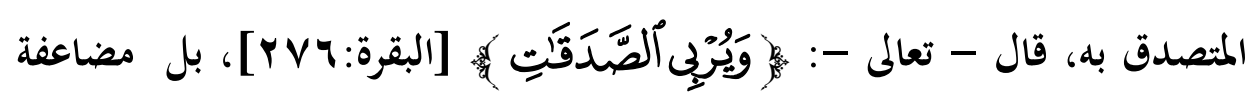

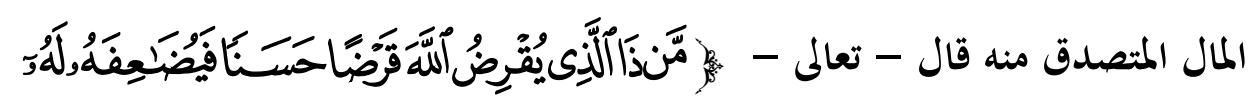

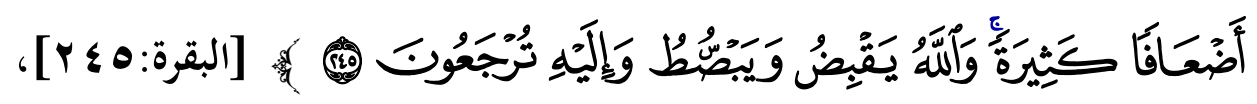

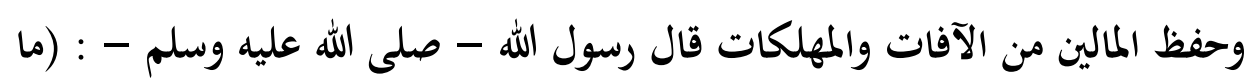

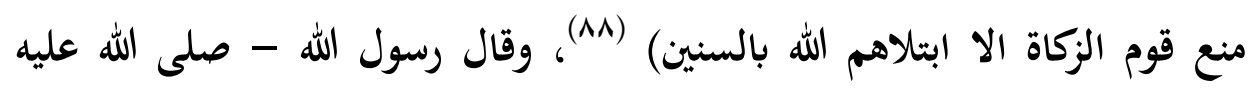

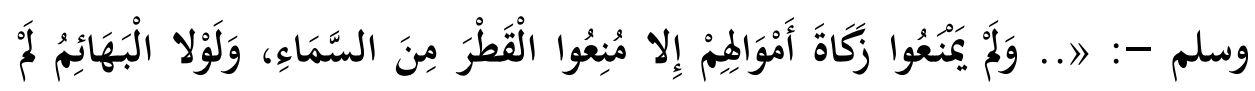

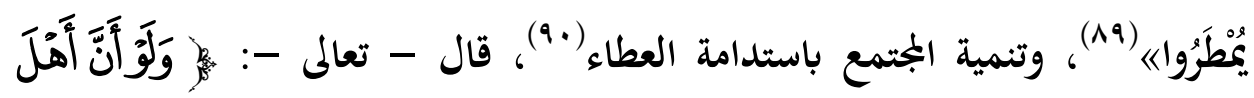




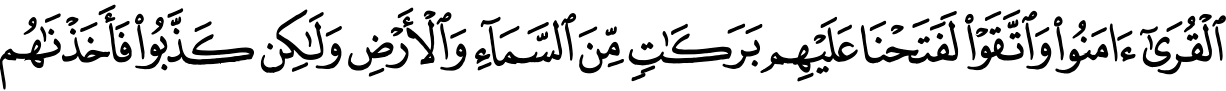

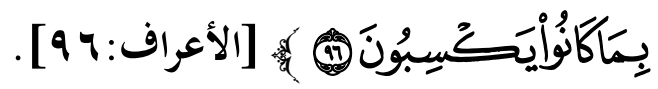
وقال رسول الله - صلى الله عليه وسلم -: قال الله - عز وجل -: 》أَنْفِق،

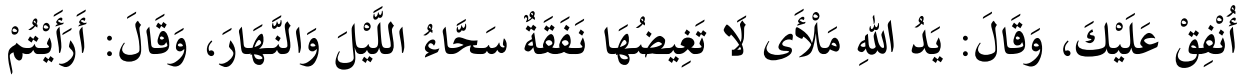

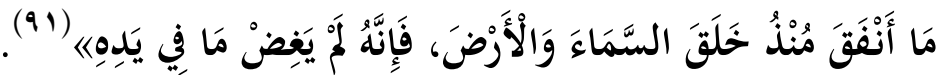
يقول الشيخ البهي الحولي: اإنه من الوجهة الاقتصادية أنجح في تثمير المال، وتمكين العبقريات الكامنة في الشعب أن تحقق مشروعاتما الصناعية والاقتصادية التي لتحن

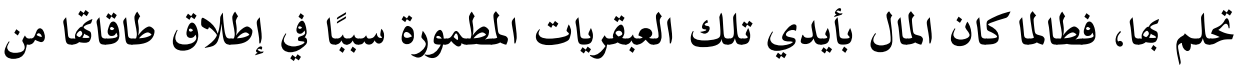
اليأس والحخمول إلى آفاق التنمية والإكثار (r). والطهارة من مقاصد الزكاة وهي تدور في فلك مقصد التوحيد وإخلاص

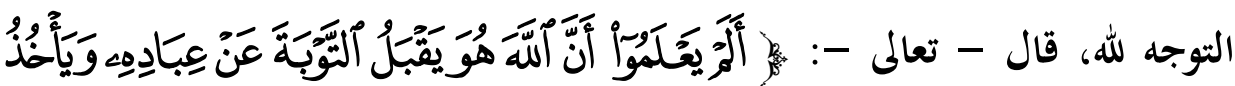

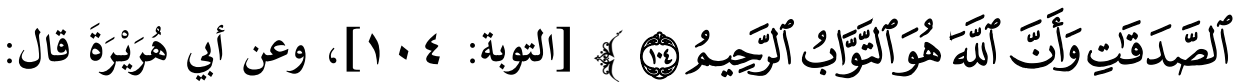

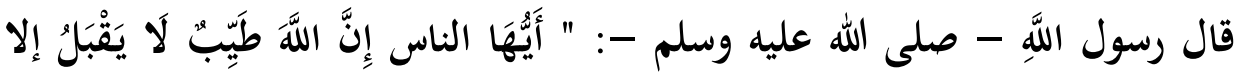

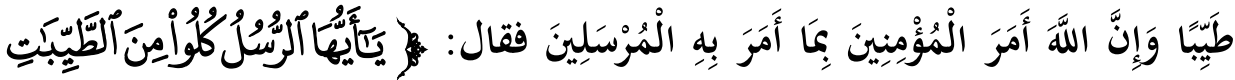

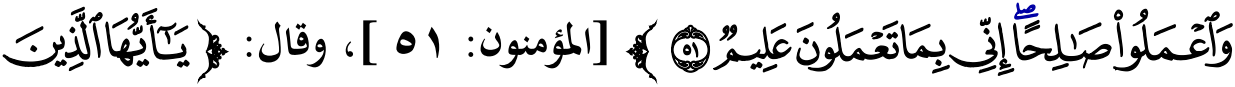

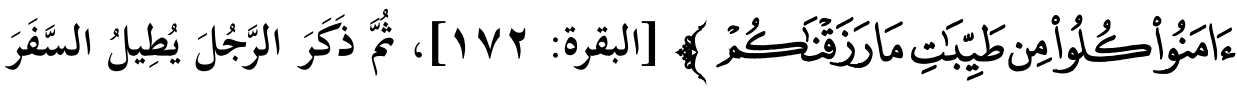

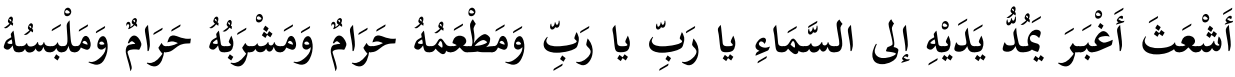

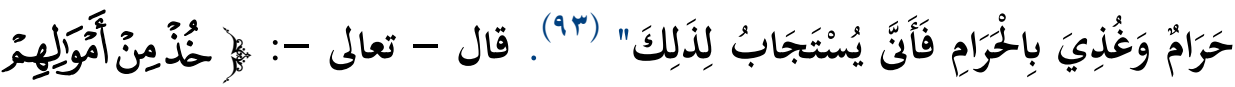

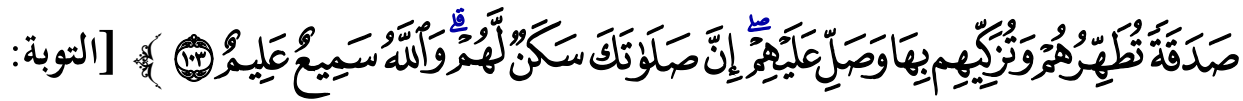
با. 1]]، والزكاة بهذه المقاصدية تعد طهارة مادية ومعنوية، ظاهراً وباطناً، عاجلاً

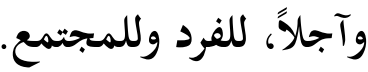


المطلب الثاني: مقصد إقامة العدل ودفع الظلم. العدل: خلاف الجور، وهو في اللغة: القصد في الأمور، وهو القسط،

والإنصاف، وعدم الجور (\&).

وأصله: التوسط بين المرتبتين. أي: الإفراط والتفريط، فمن جانب الإفراط

والثفريط فقد عدل (90).

والشريعة عدل كلها، العدل هو مبناها وأساسها ومقصدها، قال - تعالى -:

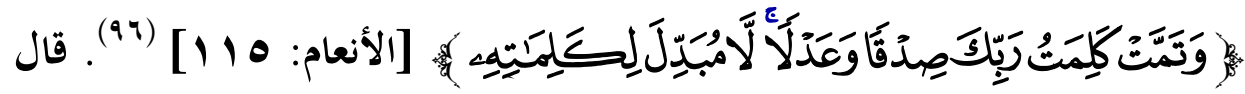
المفسرون: أي: تمت كلمة ربك صدقًا (إن كان من باب الحبر)، وعدلًا إن كان من باب التكاليف (9v) (وهو كل ما شرع الله وكلف به عباده)، قال قتادة: صدقًا فيما قال، وعدلًا فيما حكم، يقول: صدقًا في الإخبار، وعدلًا في الطلب، فكل ما أخبر الخبر فهو حق لا مِية فيه ولا شك، وكل ما أمر به فهو العدل الذي لا عدل سواه، وكل ما فهى عنه فباطل، فإنه لا ينهى إلا عن مفسدة. قال - تعالى - :

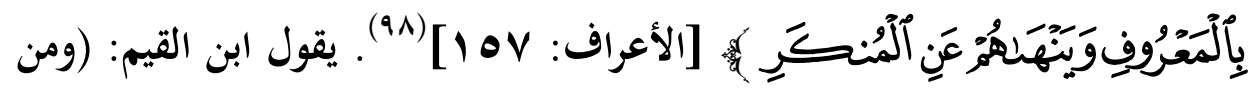
له ذوق في الشريعة، واطلاع على كمالها، وتضمنها لغاية مصالح العباد في المعاش والمعاد، وججيئها بغاية العدل الذي يسع الخلائق، وأنَّه لا عدل فوق عدلها، ولا مصلحة فوق ما تضمنته من المصالح، تبين له أنَّ السياسة العادلة جزء من أجزائها،

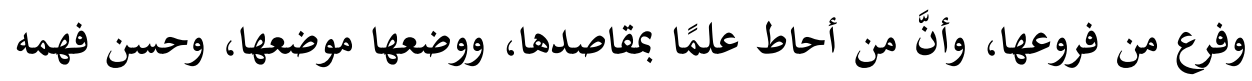

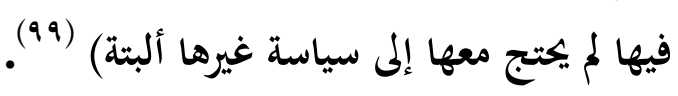
ويدخل في مفهوم العدل كل ما يحقق المقاصد الشرعية كما أرادها الله لتقوم به

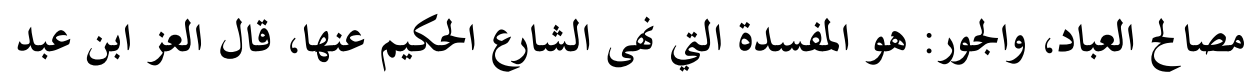

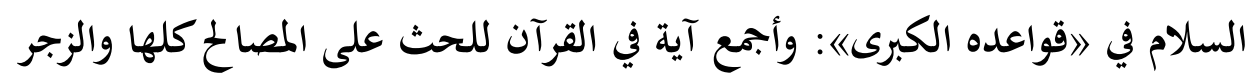
عن المفاسد بأسرها قوله - تعالمى -: إِ 


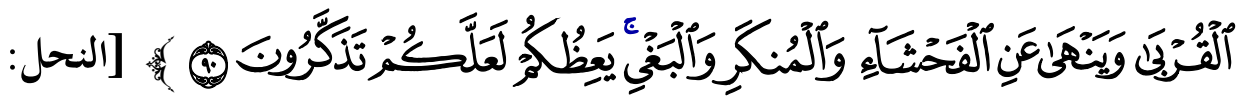
. [9.

فِإن الألف واللام في العدل والإحسان للعُعُوم والاسْتِفْرَاق، فلا يبقى من دَقِّ

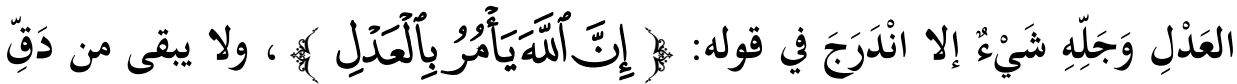

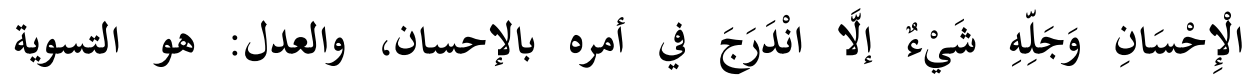
والإنصاف (1..).

ولا يقصد بالتسوية والإنصاف الأداء الجرد البعيد عن تقدير المصالح ومراعاة

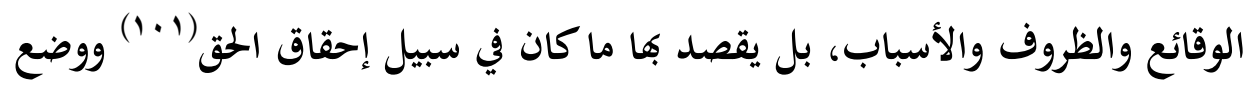
الأشياء في موضعها السليم بما يحقق المصالح ويراعي الظروف والملابسات والات والأحوال والأزمان والأمكنة والعوائد والأسباب والنيات.

يقول العز ابن عبد السلام: تقدير النفقات بالحاجات مع تفاوتها عدل وتسواتية

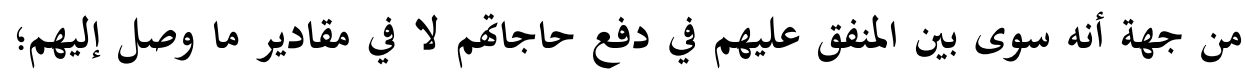

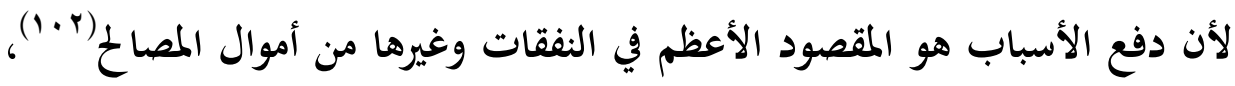

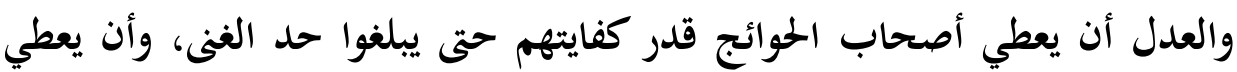

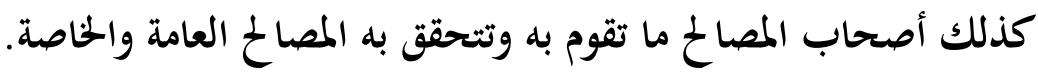

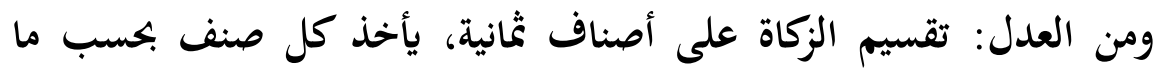

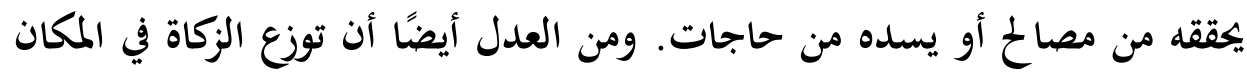

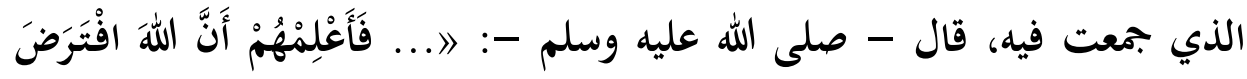

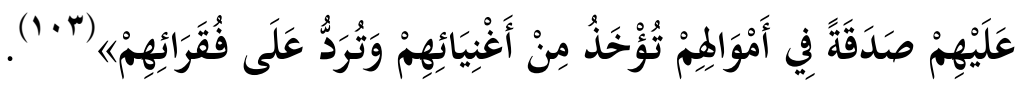

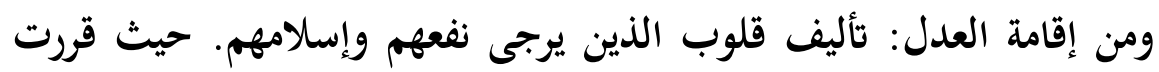

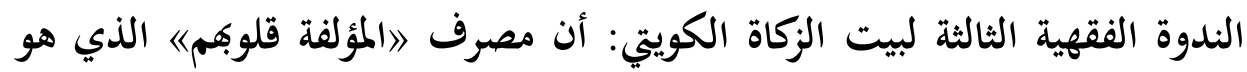


أحد مصارف الزكاة الثمانية وهو من التشريع الخكم الذي لم يطرأ عليه نسخ كما هو رأي الجمهور (ء + (1). ومن العدل حماية أبناء الأقليات المسلمة والحفاظ على أبنائهم؛ ذلك أن تعليم

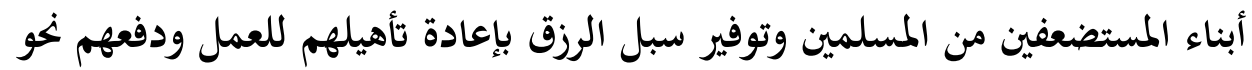

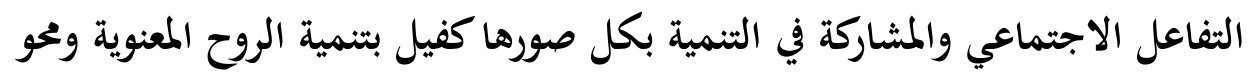
آثار المزيمة النفسية التي يعانيها أبناء الأقليات المسلمة.

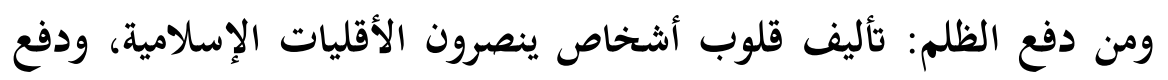
كيد الكائدين ومكر أعداء الدين. روى ابن عباس أن قومًا كانوا يأتون البي - صلى الله عليه وسلم - فإن إن إنان أعطاهم مدحو الإسلام وقالوا: هذا دين حسن وإن منعهم ذموا وعابوا (هانيا (1.). ومن العدل ودفع الظلم إيجاد مؤسسات إعلامية للاستفادة من الإعلام في

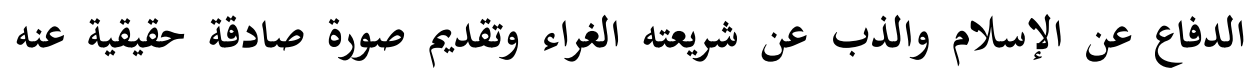
توضح مفاهيم الدين ومقاصده حتى لا تقع الجُتمعات غير المسلمة أو المسلمين

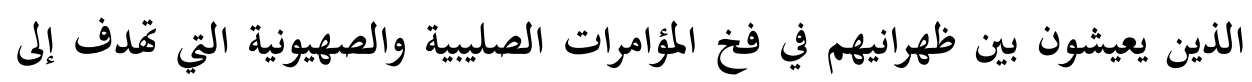
تشويه حقيقته وتقديمه في صورة الإرهاب والعنف والتخلف والجمودد.

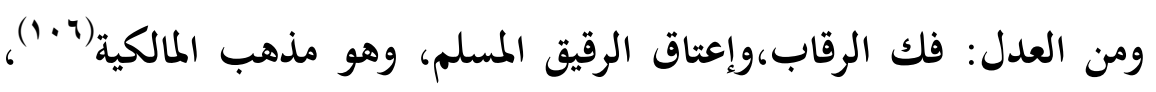

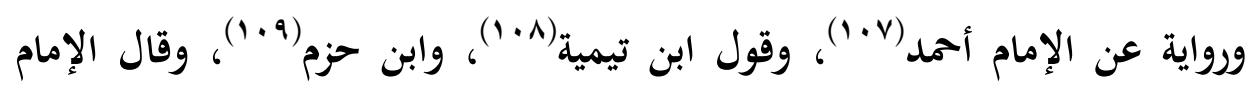
مالك: من اشترى من زكاة ماله رقبة فأعتقها كما يعتق الوالي أن ذلك جائز الئز ويجزئه ويكون ولاؤه لجميع المسلمين (.1'). ومن العدل: إطلاق سراح الأسرى بأن يفتدي بالزكاة أسيرًا مسلمًا من ولمدين

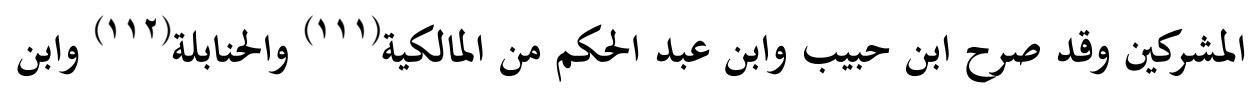

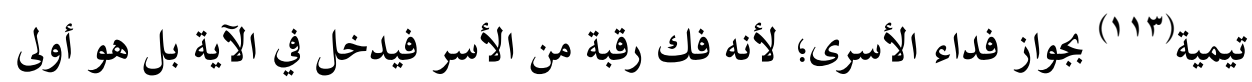
من فك رقبة من بأيدينا وصرح المالكية بمنعه( (1) . 
ونصت الفتوى الشرعية لبيت الزكاة الكويتي في فكاك الأسرى من هذا المصرف فقد نصت على جواز فكاك الأسرى من أموال الزكاة من مصرف لاوفي الرقاب《، وهذا مذهب الحنابلة وقول ابن رجب، وقول ابن عبد الحكم من

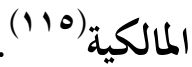

ومن إقامة العدل ودفع الظلم: إعطاء الدائنين المعوزين خاصة أصحاب

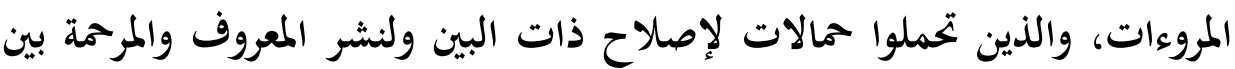
الناس، فمن العدل دفع الظلم بإقالة عثراتم. ومن العدل: مماية الأمة الإسلامية من التبعية الثقافية؛ وذلك بإعداد الدعاة الأكفاء وإنشاء كليات ومعاهد دعوية تعمل على تأهيل الدعاة ونشر الثقافة الإسلامية وصد الهجمات الصليبية والوثنية واللادينية وسائر المذاهب المدامة التي تغزو عقول المسلمين وتمدد هويتهم، يقول الشيخ رشيد رضا: ومن أهم ما ينفق في

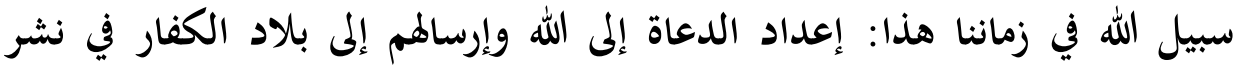
دينهم... وتدخل فيه النفقة على المدارس للعلوم الشرعية وغيرها بما تقوم به

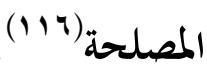

ومن العدل: صيانة أنفس أبناء السبيل عن الهلاك بتوفير حاجاتم الأساسية؛ ذلك أن مقصود الزكاة كما قال الثاطبي: رفع رذيلة الشح، والإرفاق بالفقراء

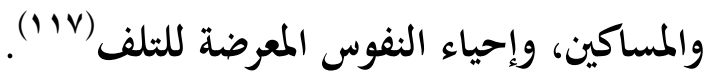
المطلب الثالث: مقصد تحقيق النماء ودفع النقصان والهلاك:

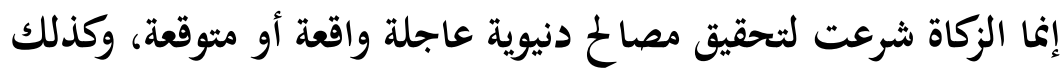
مصالح أخروية آجلة متحققة. كما أن المعنى اللغوي للزكاة له أبعاد مادية ومعنوية، وأن النماء من معالي الزكاة ومقاصدها، وأن النماء المادي يكون بالزيادة والنمو والريع والخصب والحير، 
أما النماء المعنوي فيكون بالمدح والثناء وطهارة النفس من أدناسها وبالبركة وبالأجر

والمثوبة.

ولا شك أن هذه المعاني اللغوية أصل للمعالن والمقاصد الثرعية، يقول ابن

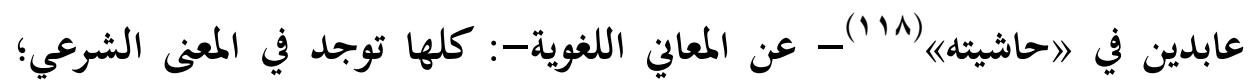
لأفما تطهر مؤديها من الذنوب ومن صفة البخل والمال بإنفاق بعضه؛ ولذا كان

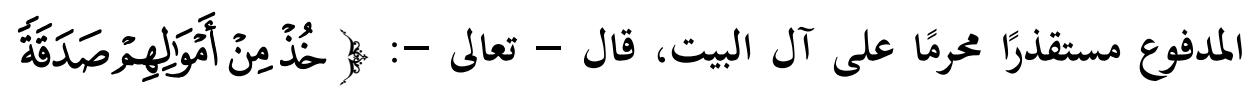

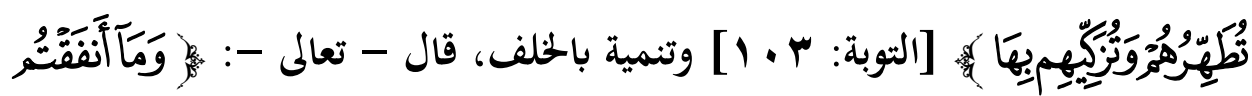

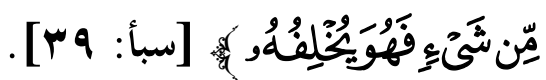

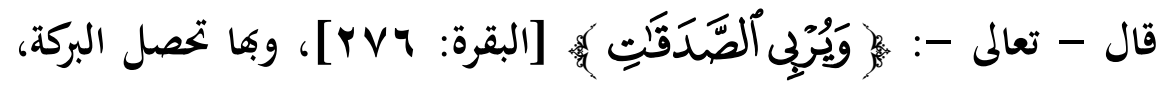

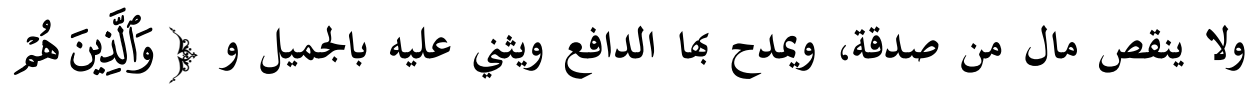

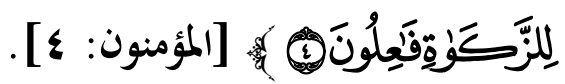
والمتأمل في كتاب الله - عز وجل - وسنة النبي- صلى الله عليه وسلم - يجد تواترًا على أن الزكاة إنما شرعت للنماء بكل ما لمان تحمله الكلمة من أبعاد مادية ومعنوية

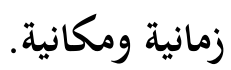

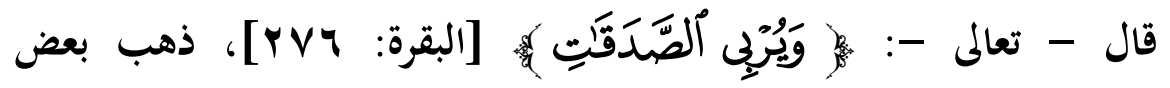

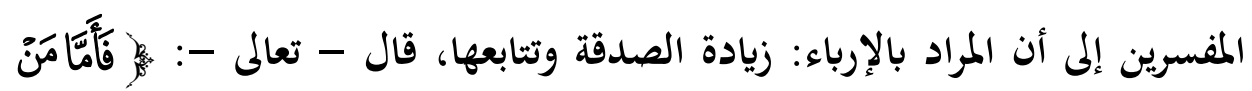

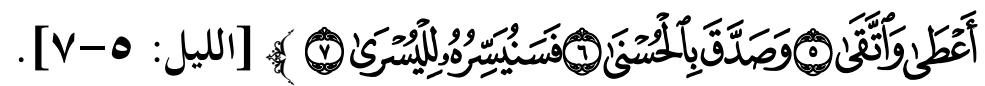
أي: سنيسر له الإنفاق في سبيل الحير، والعمل بالطاعة لله (19")، قال - تعالى --

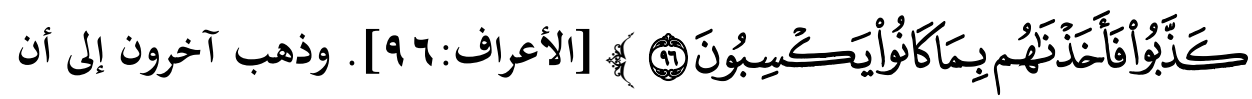

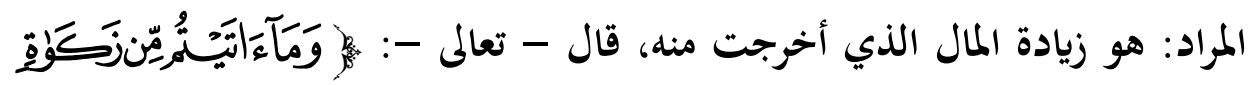




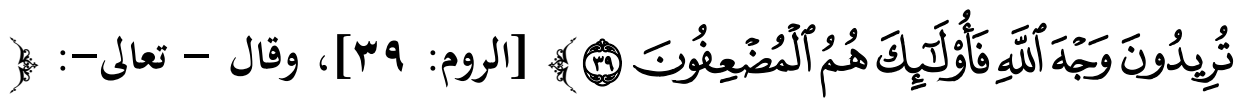

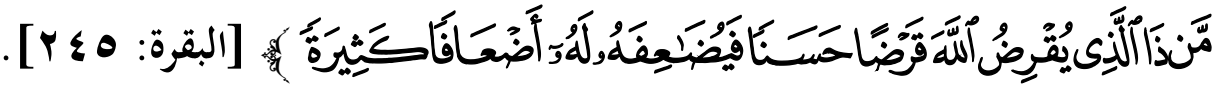

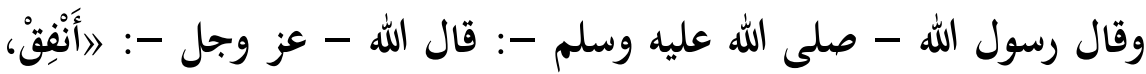

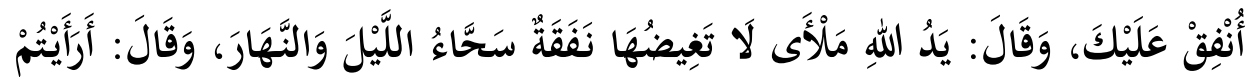

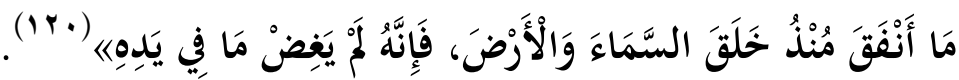

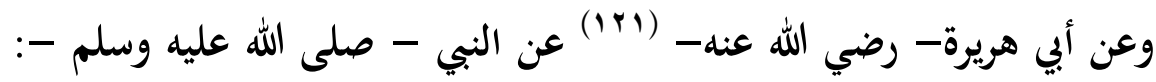

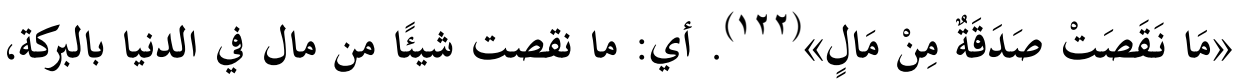

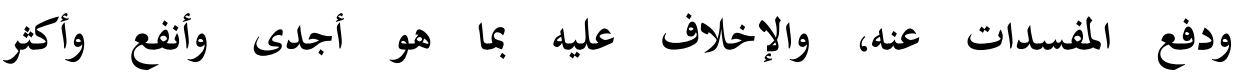

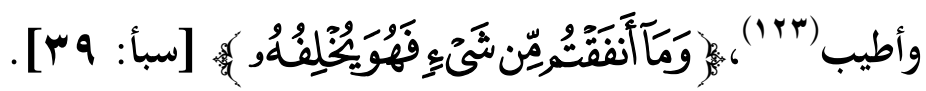
والمعنى: ما نقص مال عبد من صدقة. أي: من أجل إعطاء صدقة؛ لأفها

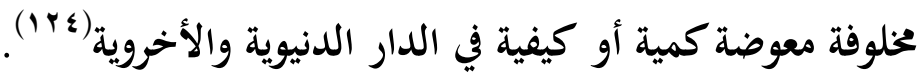

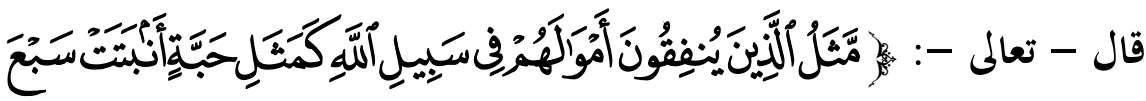

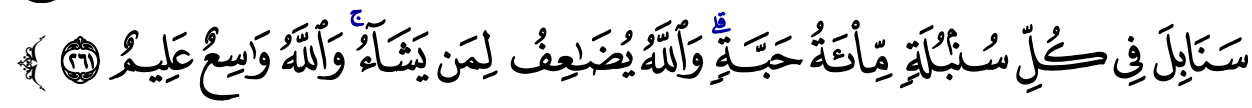

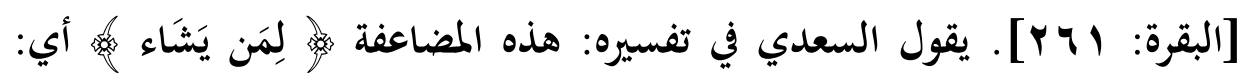
بحسب حال المنفق وإخلاصه وصدقه، وبحسب حال النفقة وحلها ونفعها ووقوعها

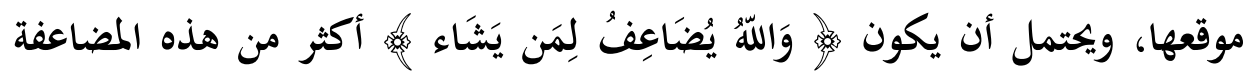

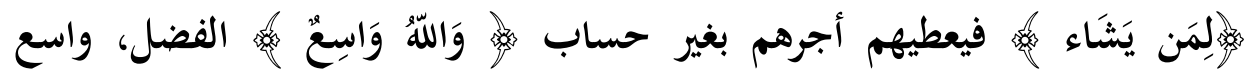

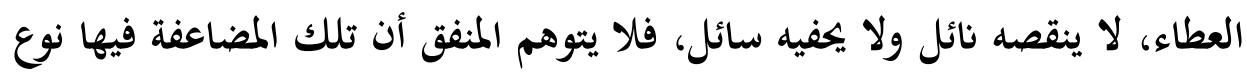

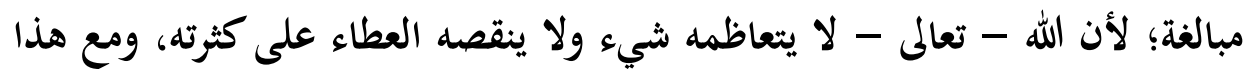

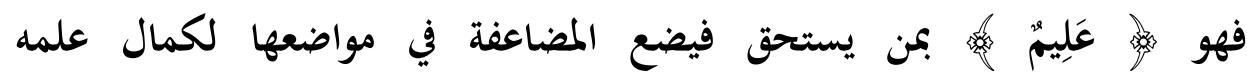
وحكمته(ro) (1ro) 


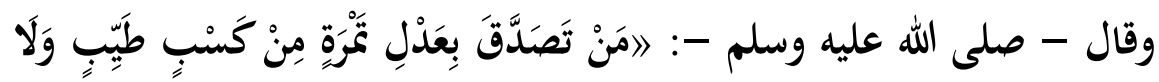

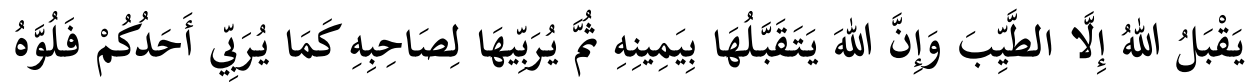

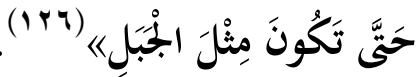
ومضاعفة الأجر مرهون بالإخلاص لله وإرادة تنمية الفقير بإمداده بالمال النامي بالقوة أو بالفعل، وبقوة صدق الإخلاص، وباستدامة النفع والنماء يعظم أثر النفقة

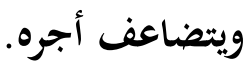

قال ابن عطية(1rV) : شبه نمو نفقات هؤلاء المخلصين الذين يربي الله صدقاتم كتربية الفصيل والفلو بنمو نبات هذه الجنة بالربوة الموصوفة، بخلاف الصفوان الذي انكشف عنه ترابه فبقي صلدًا (IrA) وهكذا تواترت النصوص على أن الزكاة- هذه العبادة المالية- شرعت للنماء:

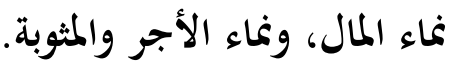
والزكاة في مفهوم الاقتصاد الإسلامي المعاصر، تعد أهم أدوات السياسة المالية

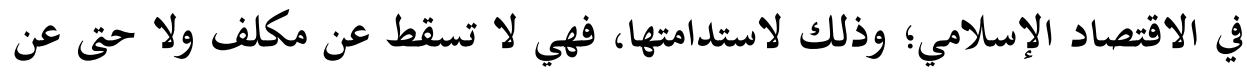

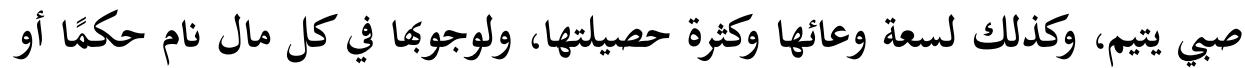

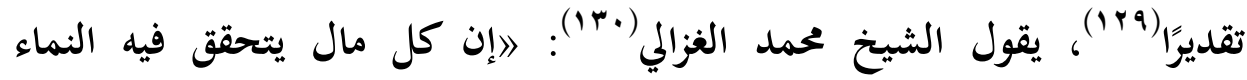
والشروط التي ذكرها الفقهاء تجب فيه الزكاة، ولو لم يكن جاء به النص عن رسول

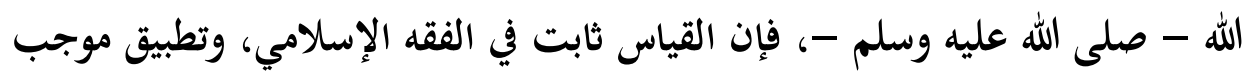

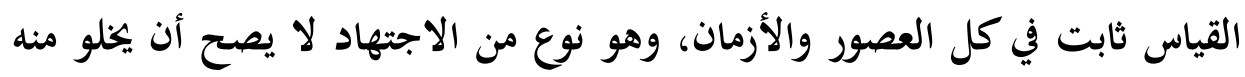

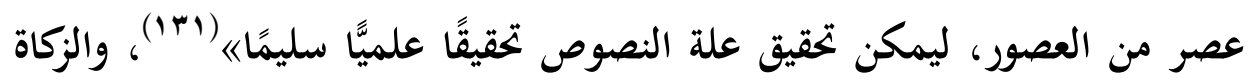

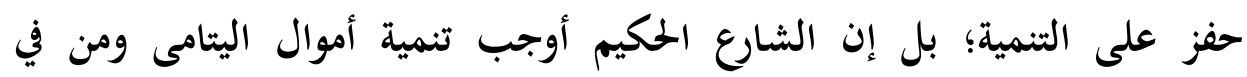

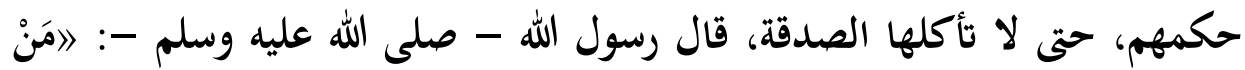

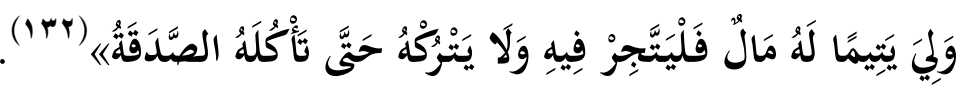


وأخرج البيهقي في 》سننهان بسنده عن عمر بن الخطاب- رضي الله عنه- أنه النه

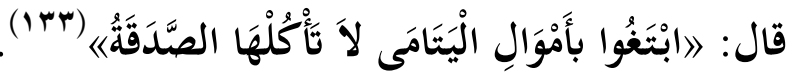

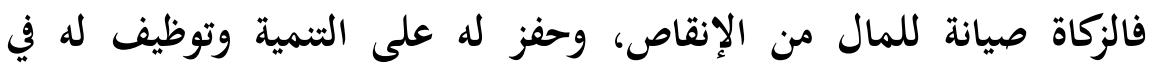
الاستثمار والاتجار، وإذا نوهنا بعكسية العلاقة الطردية بين الزكاة وبين الدخل،

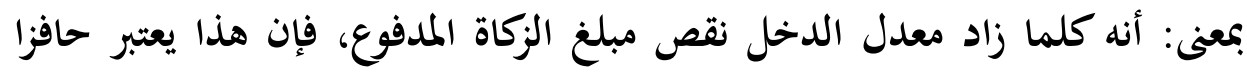
لاستثمار الدخل، وتوظيفه في مشروعات الاستثمار الإنمائي الإنتاجي والاستهلاكي، مما يؤدي إلى حفز الإنتاجية ومضاعفة الدخول وتحقيق مستويات أعلى من النمو

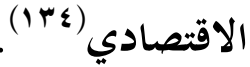

ومن الأوجه التنموية للزكاة: أفا تحول دون الكنز، قال - صلى الله عليه وسلم

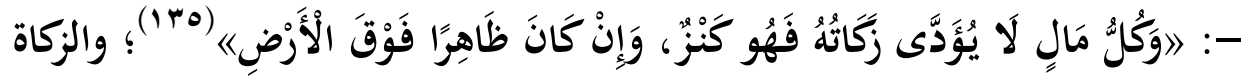
تعمل على تداول النقد وإعادة توزيع الثروات بين أفراد الجتمع. ومن الأوجه التنموية: أن الزكاة ما شرعت إلا لسد حاجة المعوزين والمختاجين من الفقراء والمساكين، فهي بذلك أحد أساليب معالجة الفقر، قال رسول الله - صلى الله عليه

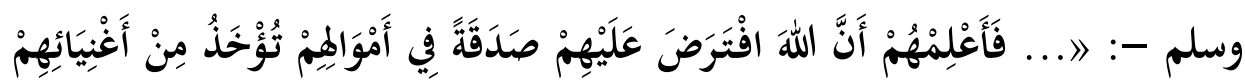

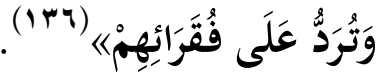

من الأوجه التنموية: زيادة معدلات الطلب الكلي والاستهلاكي والإنتاجي،

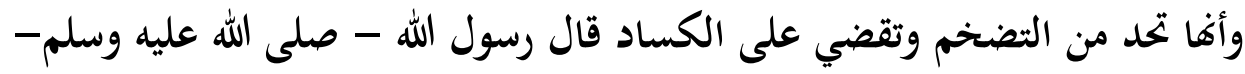

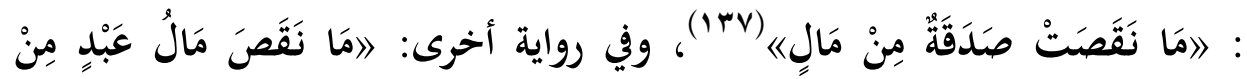

صَدَقَقِة

ومن أوجه التنمية: دورها في محاربة البطالة؛ ذلك أن الزكاة لا تحل لغني ولا

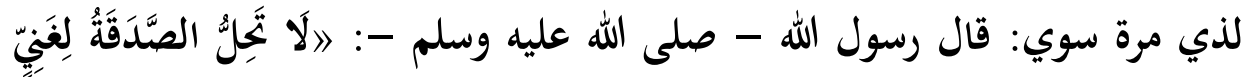

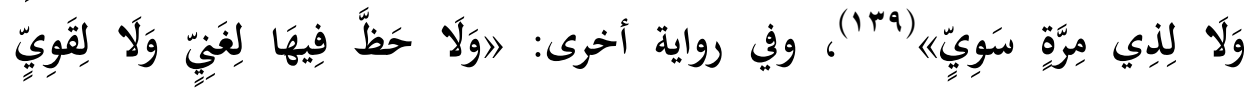

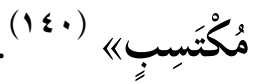


وجاء في 》غاية المنتهى": 》يعطى محترف ثمن آلة وإن كثرت، وتاجر يعطى رأس

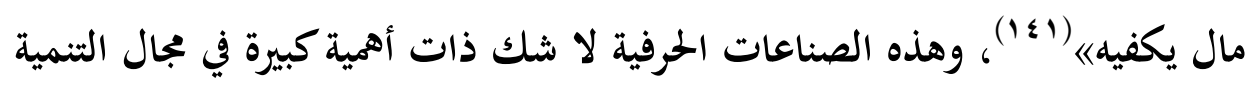
الاقتصادية؛ لأنما غير مكلفة وتقوم على أدوات بيئية متوفرة وآلات بسيطة يمكن

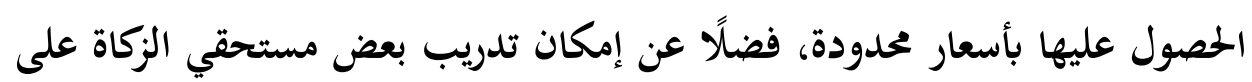

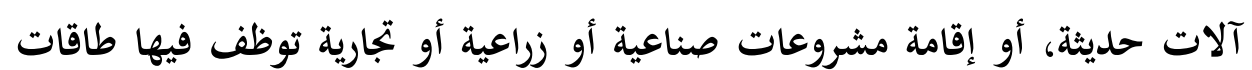
مستحقي الزكاة، مقابل ما يعود عليهم من دخل يوفر لهم حياة كريمة.

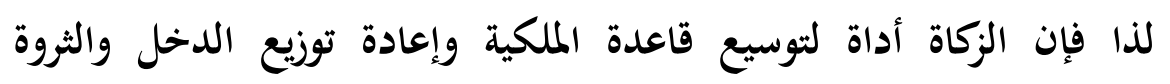

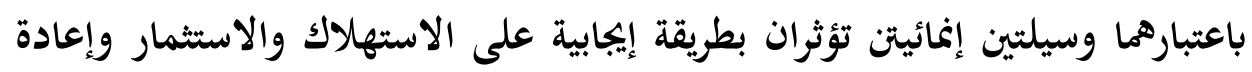
تخصيص الموارد الاقتصادية.

المطلب الرابع: مقصد الطهارة ودفع الرذائل والحبائث:

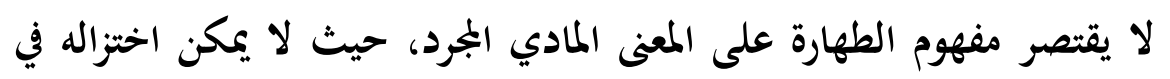

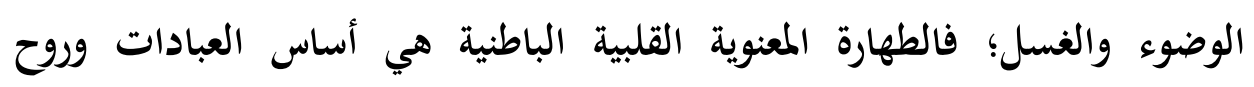
الشرائع.

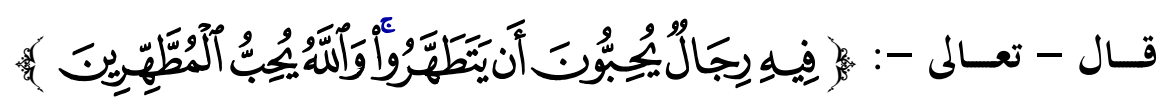

$$
\text { [التوبة: } 1 \text { • 1 ] }
$$

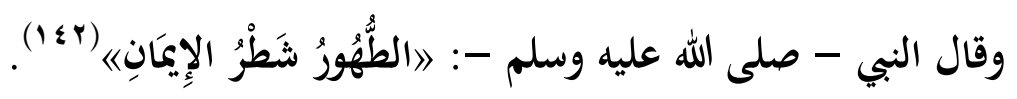

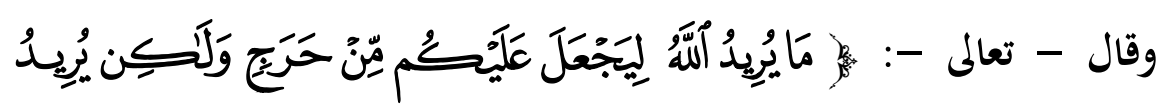

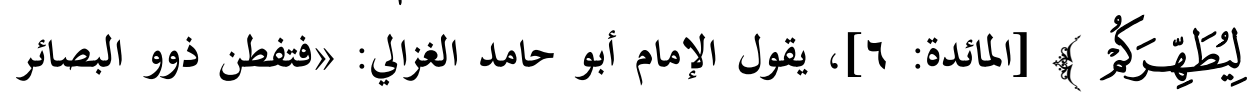

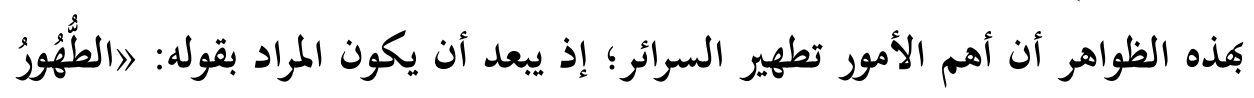

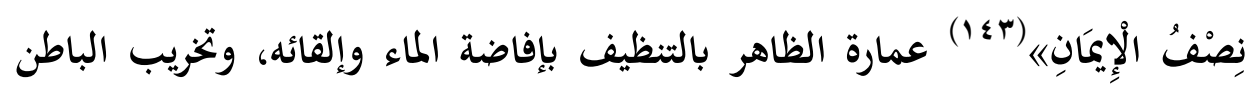

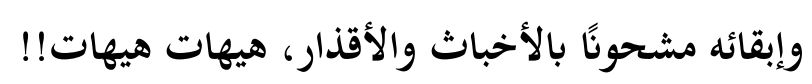




$$
\text { والطهارة لما أربع مراتب: }
$$

المرتبة الأولى: تطهير الظاهر عن الأحداث وعن الأخباث والفضلات. المرتبة الثانية: تطهير الجوارح عن الجرائم والآثام.

المرتبة الثالثة: تطهير القلب عن الأخلاق المذمومة والرذائل الممقوتة. المرتبـة الرابعـة: تطهير السرٍّ عمـا سِـوى الله - تعـالم -، وهي طهارة الأنبيـاء

$$
\text { صلوات الله عليهم والصديقين. }
$$

والطهارة في كل رتبـة نصف العمل الذي فيها، فِإن الغايـة القصـى في عمل

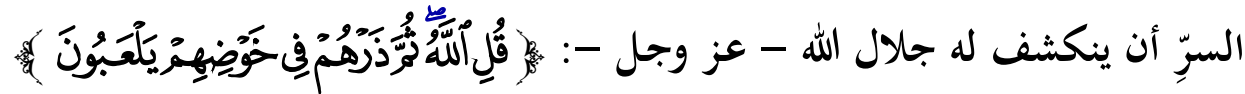
[الأنعام: 19]

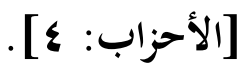

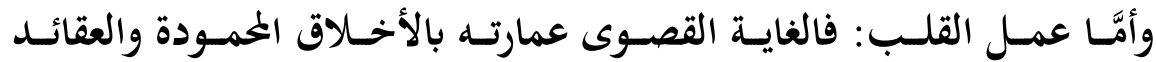
المشـروعة، ولن يتصف بـا مـا لم ينظف عن نقائصسها من العقائد الفاسـدة والرذائل الممقوتة، فتطهيره أحد الثطرين وهو الشطر الأول الذي هو شرط في الثاني، فكان الطهـور شــر الإيمـان بــذا المعـنى، وكـذلك تطهـير الجــوارح عـن المنــاهي أحســ الشطرين) ( ؛ ؛ ( ).

بل إن طهارة الباطن هي الأصل في الطهارة، وهي المقصود الأول من تشـيع العبادات، والزكاة باعتبارهـا إحـدى هذه التشريعات مـا شرعت إلا لتطهير صـاحبها

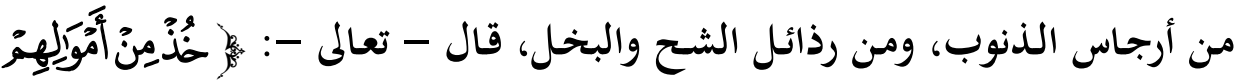

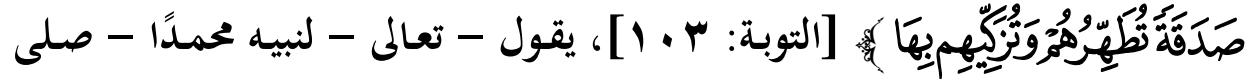
الله عليه وسلم -: يا محمد خذ من أموال هؤلاء الذين اعترفوا بذنوبمم صدقة تزكيهم

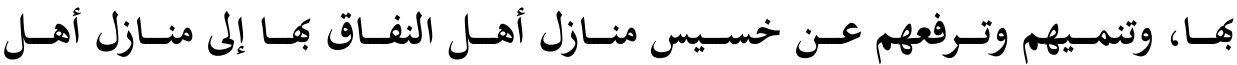
الإخلاص (0؛ ) والتطهير: إذهاب ما يتعلق بهم من أثر الذنوب. والتزكية: مبالغة في 
النطهير وزيادة، والمعنى فيه(؟؛ (1): تطهرهم من الذنوب والأخلاق الرذيلة. وتزكيهم.

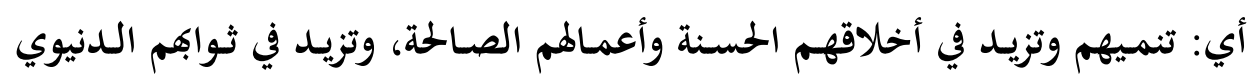

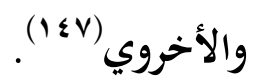

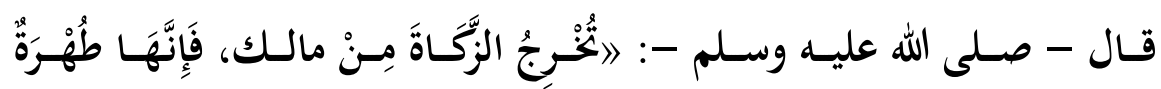

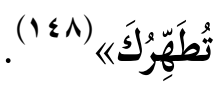

والزكاة أيضًا: تطهير لمال الغني، فيإن تعلق حق الفقير بالمال يجعله ملوثًا لا

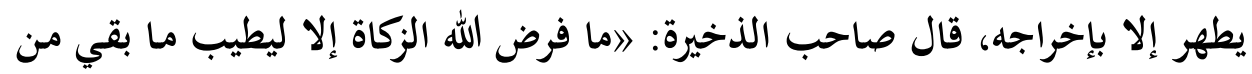

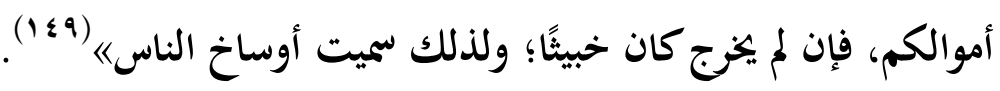

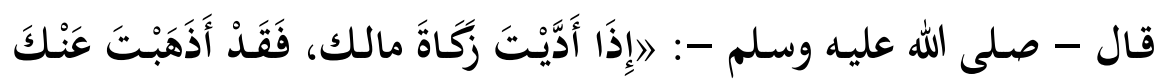
شَرَّنُ ${ }^{2}$

والزكاة تطهر آخذها من الحسسد والحقد، فالفقير الذي افترسه الفقر والعوز

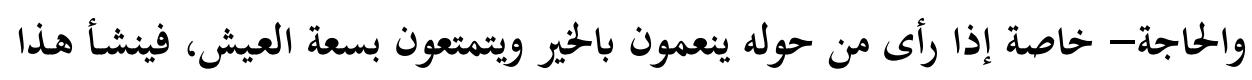

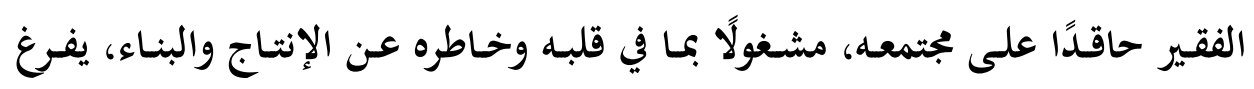

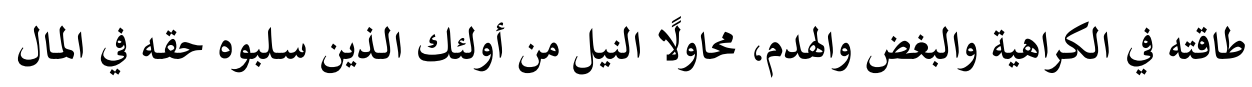

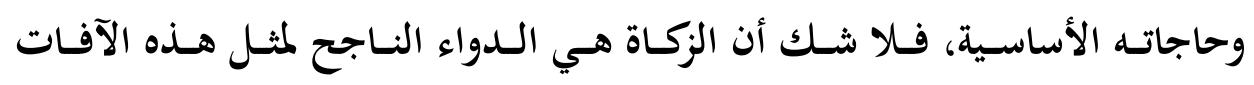

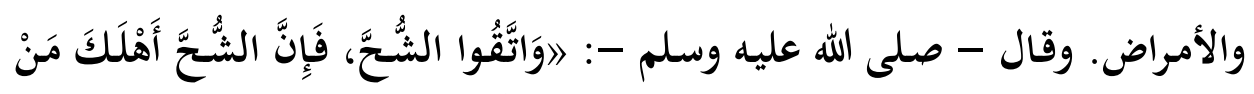

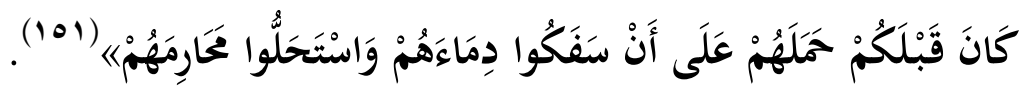

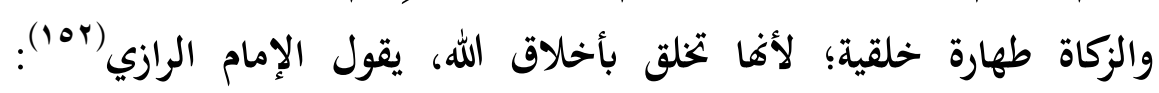

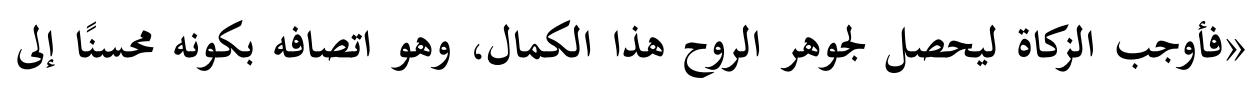

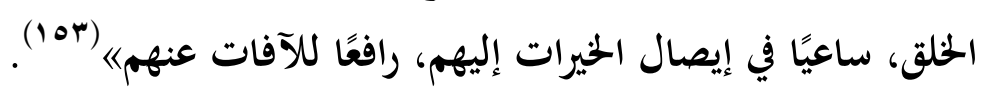

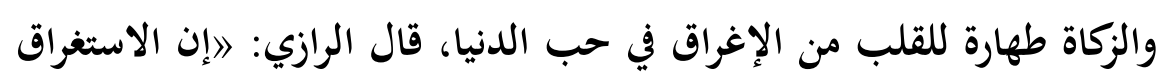

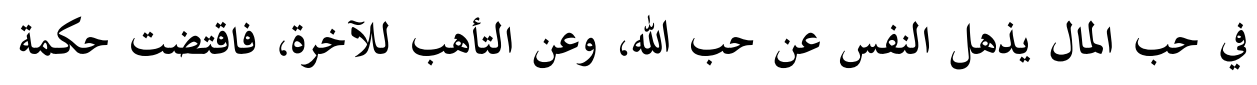

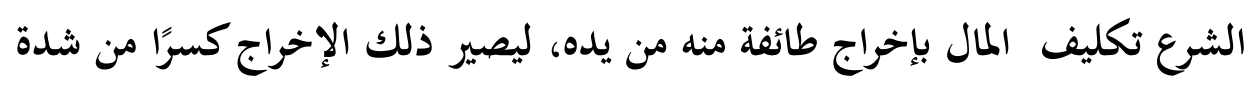




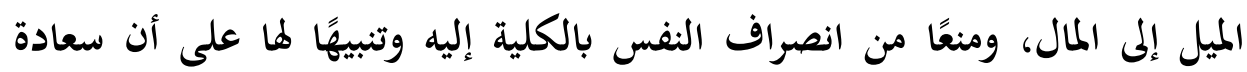

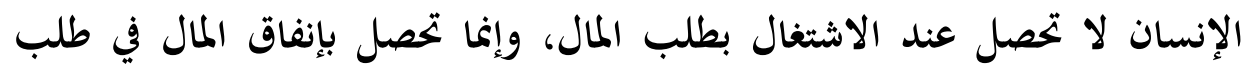

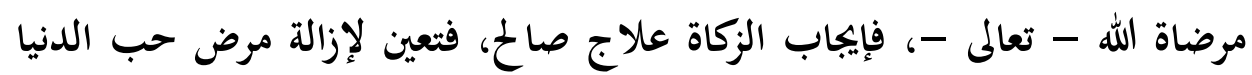

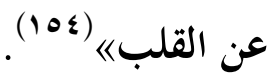
والزكاة تطهير للنفس من الطغيان والقسوة في القلب، وسببه: أن كثرة المال

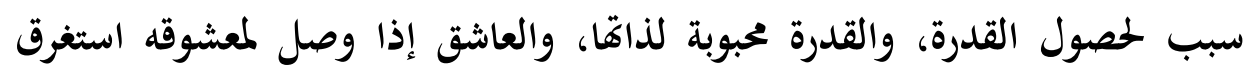

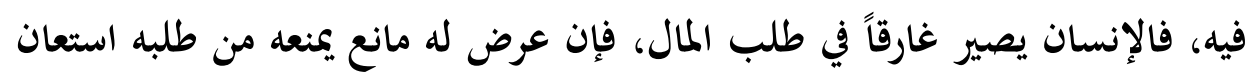
بماله وقدرته على دفع ذلك المانع، وهذا هو المراد بالطغيان وإليه الإشارة بقوله

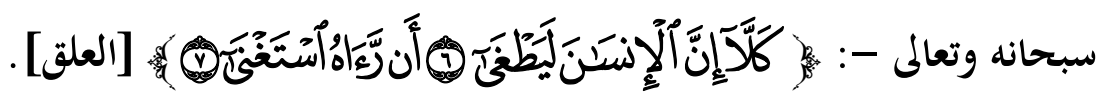
وبإيجاب الزكاة يقتل الطغيان، ويرد القلب إلى طلب رضوان الران الرحمن (100).

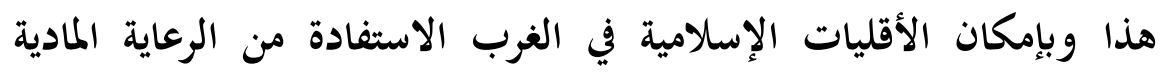

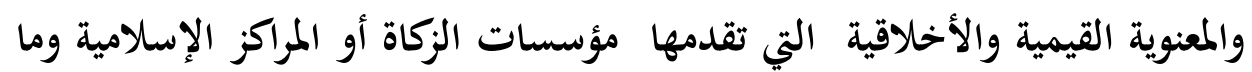

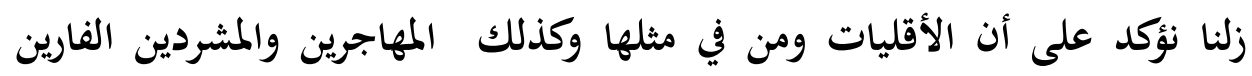

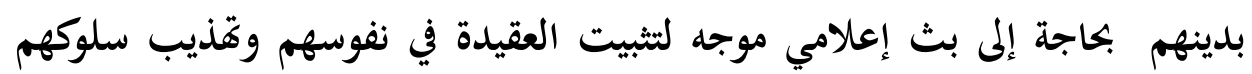

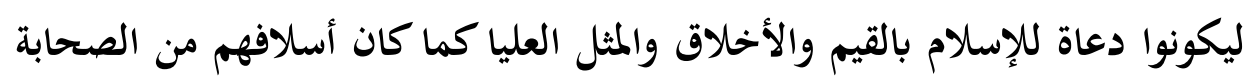
والتابعين وتابعيهم رضوان الله عليهم أجمعين. يسهم مصرف (والمؤلفة قلوبم) في ماية المستضعفين من المجمات التنصيرية،

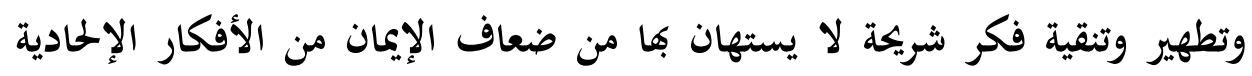

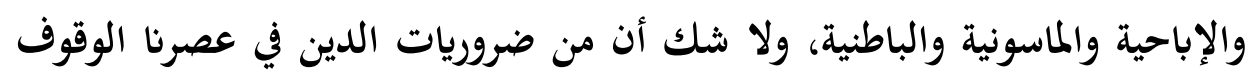
في وجه الزحف على دول إفريقيا والمستضعفين من المسلمين من قبل المنصرين

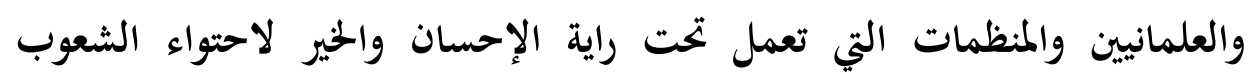

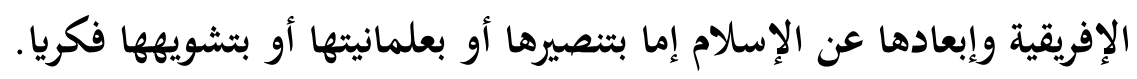


وهذا ما قرره مجلس مجمع الفقه الدولي في دورته الثامنة عشرة: أن تحرير

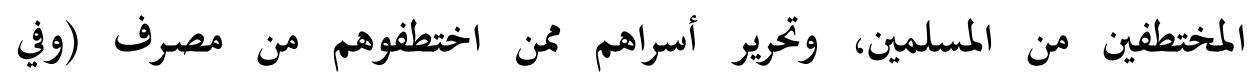

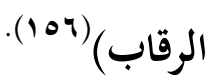

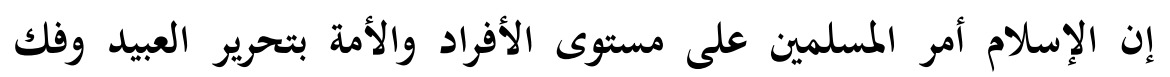

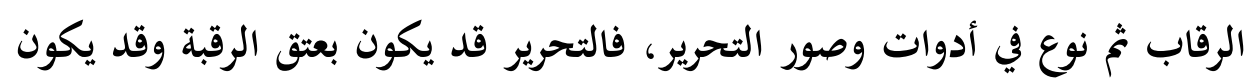

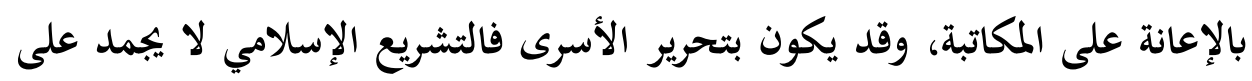

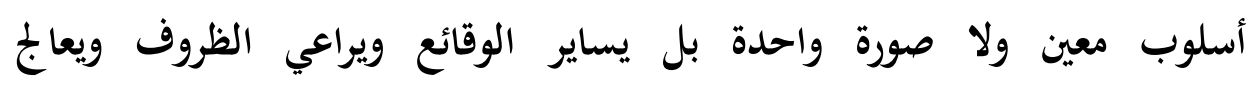
المستجدات، فالواجب على الدول الإسلامية التصدي للنخاسة المعاصرة

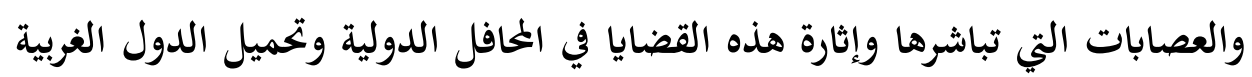

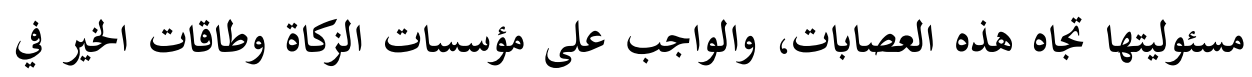

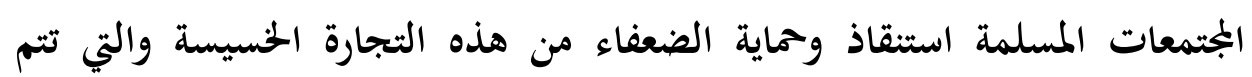

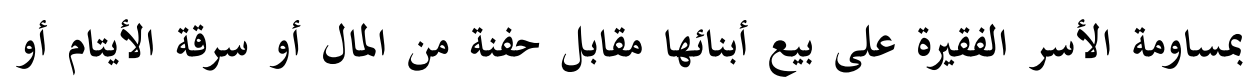

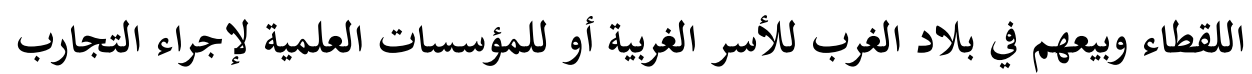

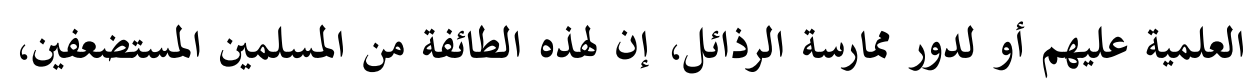

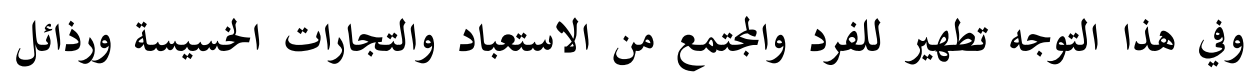
الأعمال.

المطلب الخامس: مقصد القوة والتمكين ودفع الضعف والاستعباد.

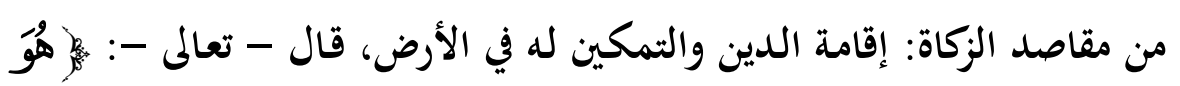

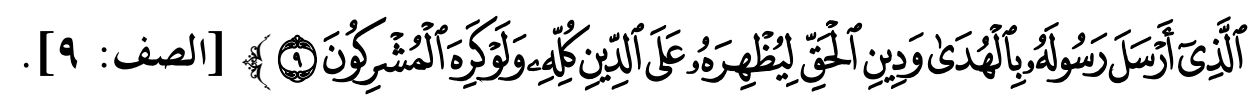

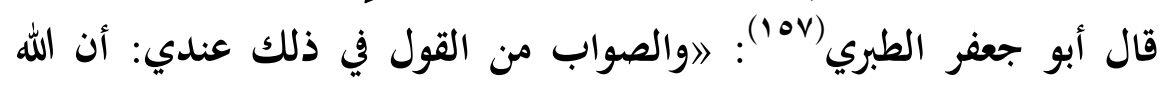

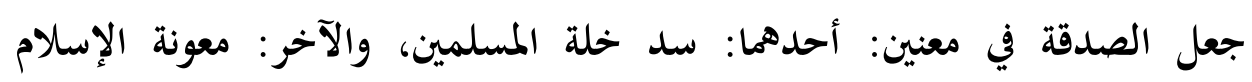

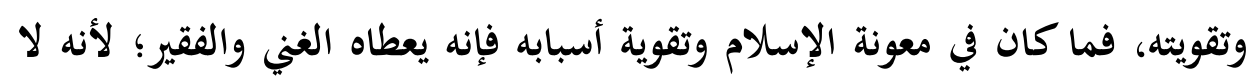


يعطاه بالحاجة منه وإليه، وإنما يعطاه معونة للدين، وذلك كما يعطى الذي يعطاه

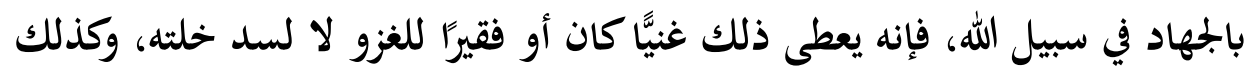
المؤلفة قلوبم يعطون ذلك وإن كانوا أغنياء استصلاحًا بإعطائهموه أمر الإسلام وطلب تقويته وتأييده) (101).

وقال ابن تيمية أيضًا: اوالصواب: أن جعل الله الصدقة في معنيين: أحدهما:

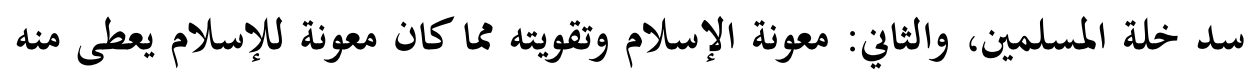

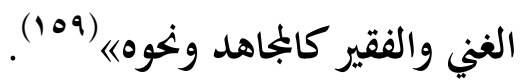
ويقول ابن القيم: 》 اكما يقطع بأن مقصوده من إيجاب الزكاة سد خلة المساكين

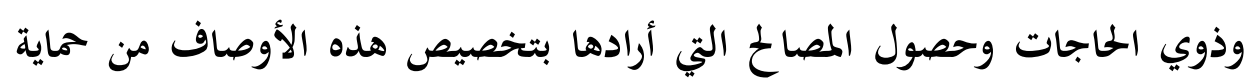

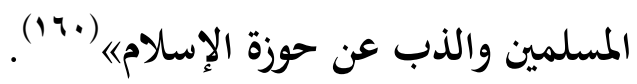
ولا شك في أن سد خلة المسلمين إنما هو دفع لعوامل الضعف وأسباب

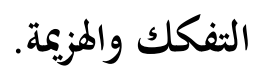
ذلك أن الزكاة حماية للفقراء والمساكين من الجوع والعري والضياع وذل المسألة

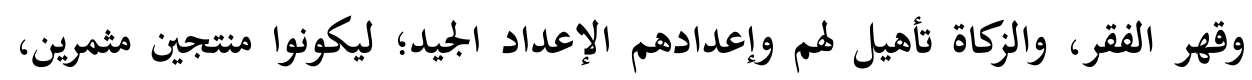

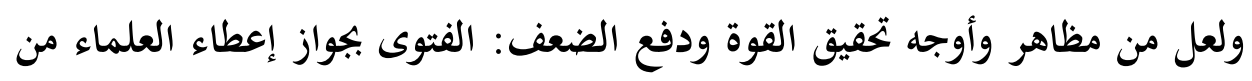
الزكاة، وإمكانية تمويل البحث العلمي الجاد.

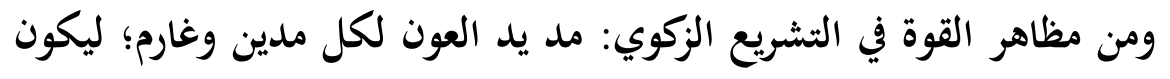

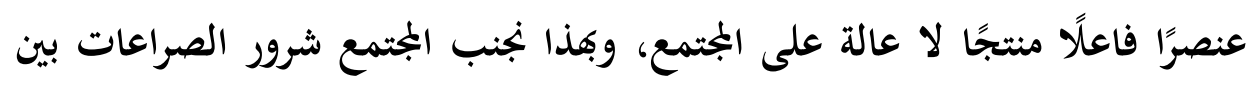

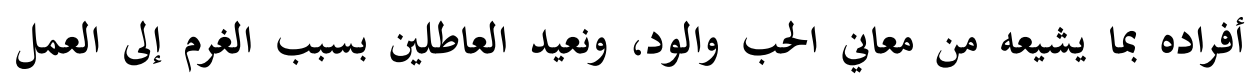

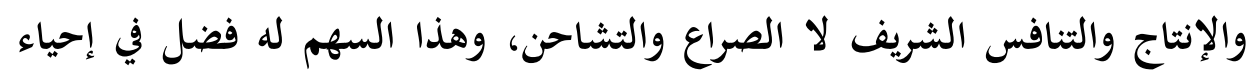

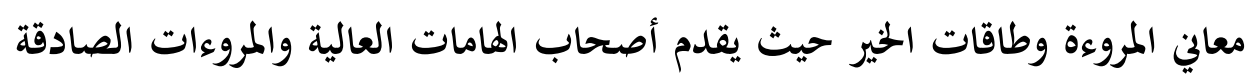

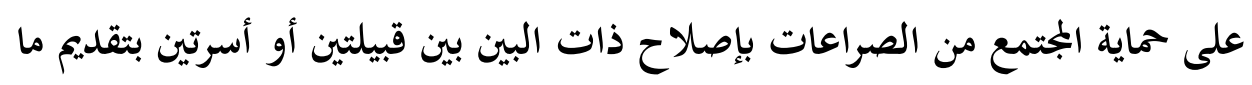


يقتضيه الصلح من ديات أو غرامات من أموالمم الحاصة؛ لإخماد نار الفتنة وتوحيد النفوس على معاني الحب والسكينة.

وليس أدل على مقصد القوة من وجوب الإنفاق في سبيل الله من حصيلة الزكاة؛ بل إنه يقدم على غيره في الأصناف إذا كان هناك ما يستدعي التقديم، قال

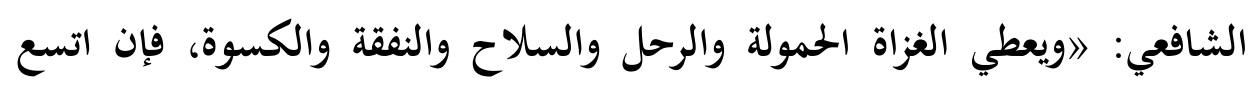
المال زيد والحيل...1) (171).

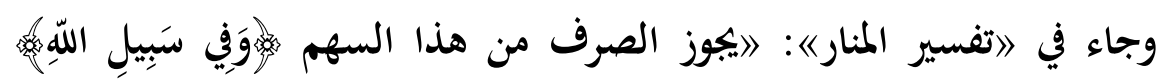

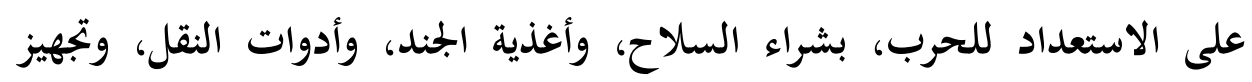
الغزاة) (1Tr). (17r).

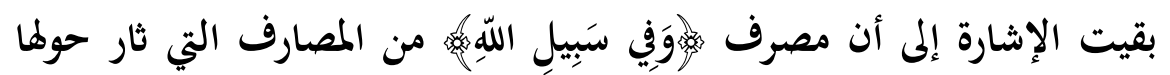

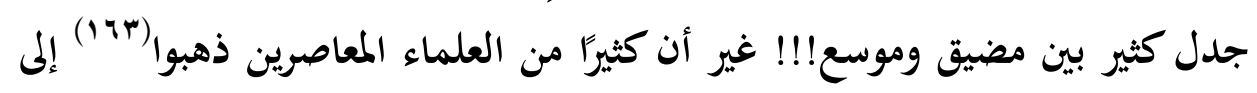

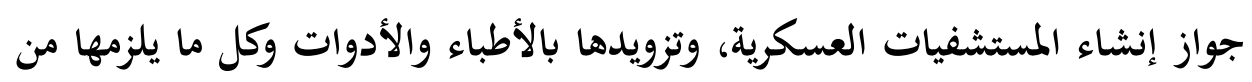

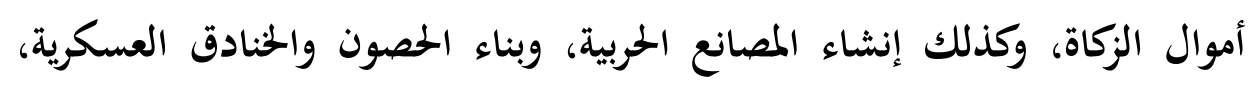

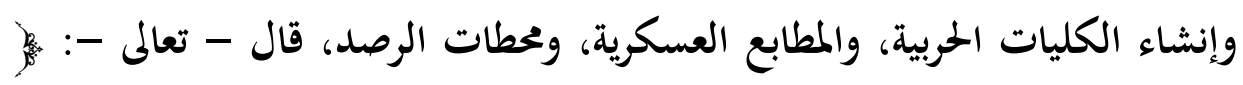

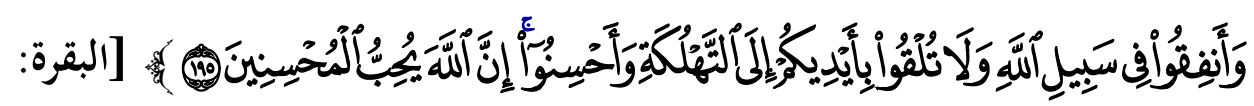
[190

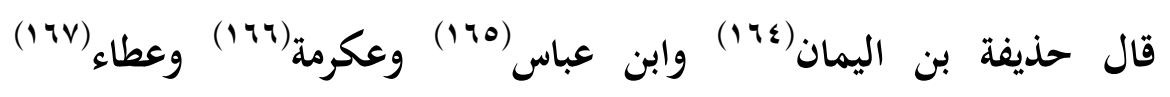
ومجاهد(1^1) وجمهور الناس: المعنى: لا تلقوا بأيديكم بأن تتركوا النفقة في سبيل الله

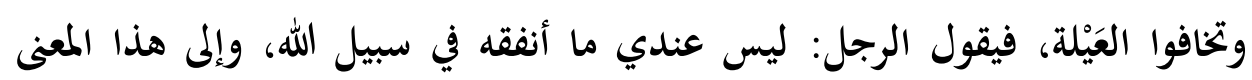

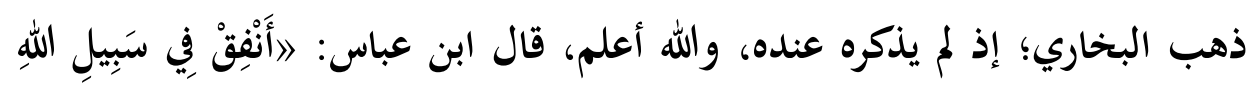

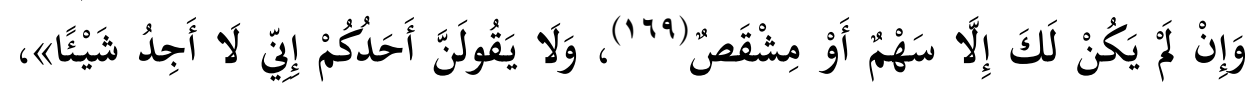




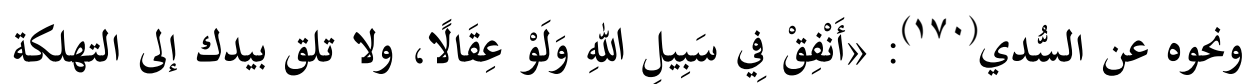

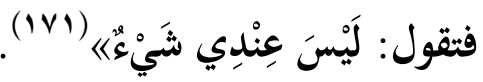

وقال ابن عباس: اومضمون الآية: الأمر بالإنفاق في سبيل الله في سائر وجوه القربات ووجوه الطاعات، خاصة الأموال في قتال الأعداء وبذلها فيما يقوى به المسلمون على عدوهم والإخبار عن ترك فعل ذلك بأنه هلاك ودمار لمن لزمه

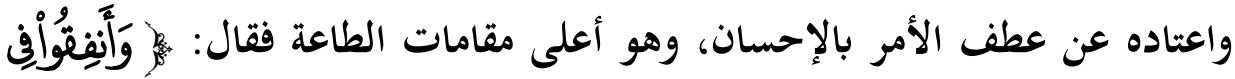

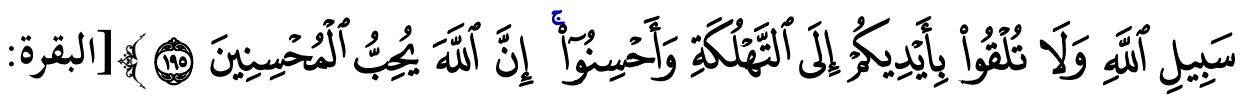
${ }^{(1 V Y)}[190$

وقال صاحب المنار: اإذا لمج تبذلوا في سبيل الله وتأييد دينه كل ما تستطيعون من مال واستعداد، فقد أهلكتم أنفسكم... وإصلاح الأموال واستثمارها في هذا الزمان هو أساس القوة، فقوى الدول على قدر ثرواتما، فالأمة التي تقصر في توفير الثروة هي التي تلقي بأيديها إلى التهلكة《(rVI) . والتي تقصر في الإنفاق في سبيل الله للاستعداد لقتال من يتعدى عليها تكون أدعى إلى التهلكة. المطلب السادس: مقصد الأمن ودفع الحوف. الحق الذي لا مرية فيه أن إيتاء الزكاة يحقق للمسلم الأمن بمفهومه الثامل: الأمن الداخلي، والخارجي، والأمن النفسي، والاجتماعي، والأمن بكل ما تحويه الكلمة من معان: الأمن بأبعاده الزمانية والمكانية. ذلك أن إيتاء الزكاة ثمرة لعقيدة صادقة راسخة في النفس، وتعبير عن إرادة

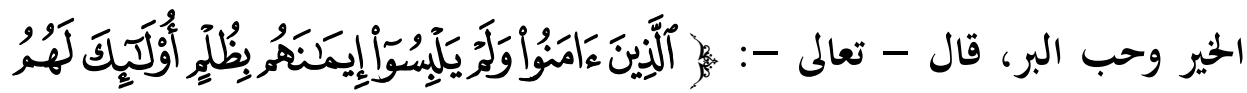

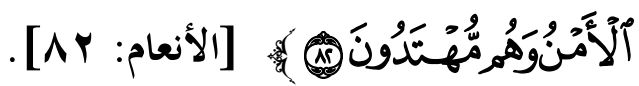


والمعنى: هو أن المؤمن تنجذب روحه إلى الحق الأزلي، والقوة الغالبة المهيمنة

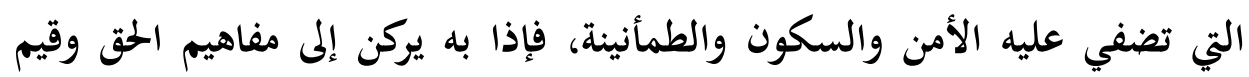

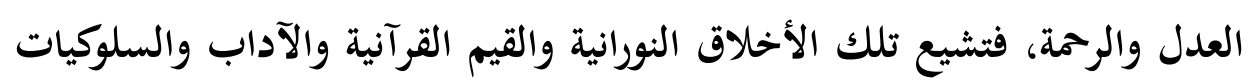
الخمدية. فإذا بالغني المعطي تمتلئ روحه بالرحمة والشفقة والحب والحير، وتم نفسه

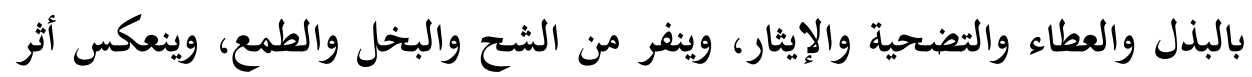

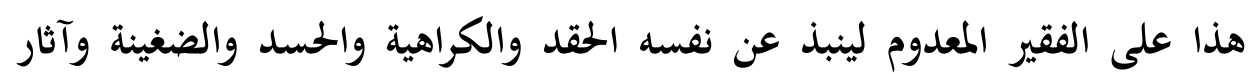

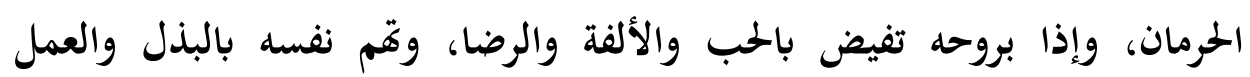

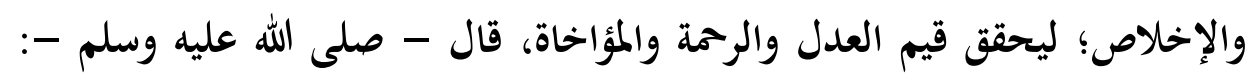

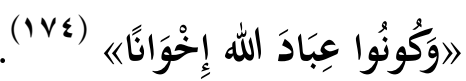

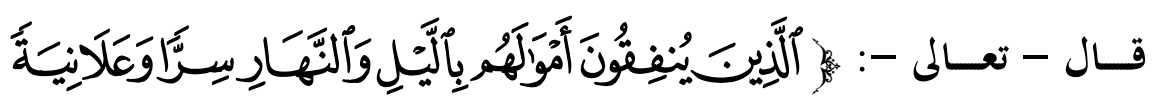

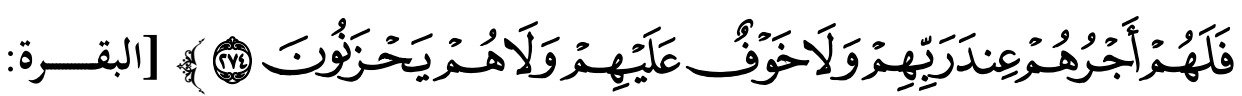
. [rV

قال الإمام الشوكاني(1V0) في 》فتح القدير《: (لالا للدلالة على شمول النفي

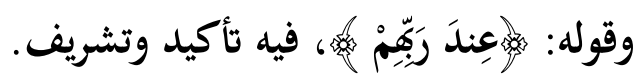

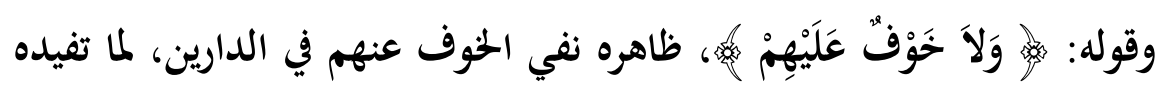

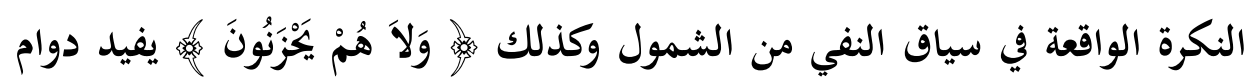
انتفاء الحزن عنهم (VI) .

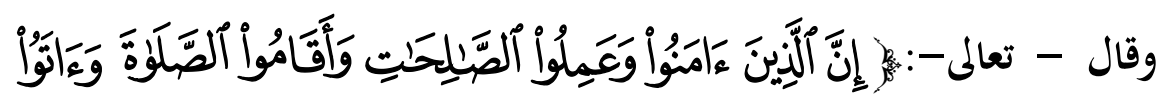

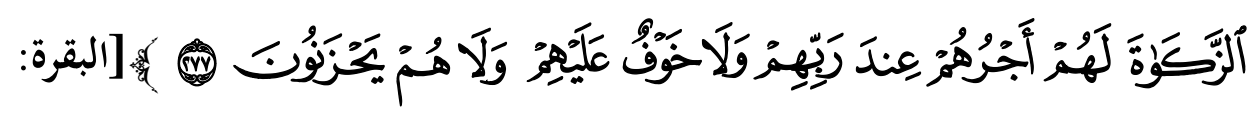
.[rVV 


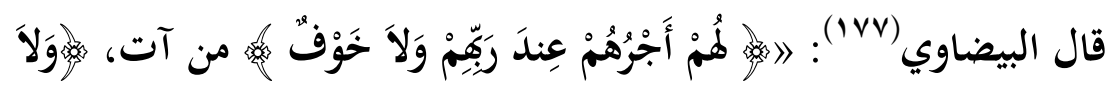

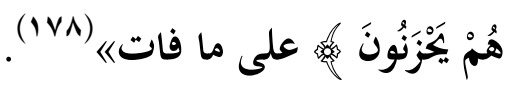

فالإمام الشوكاني يشير إلى أن نفي الحخوف عن المؤمنين الذين يقيمون الصلاة

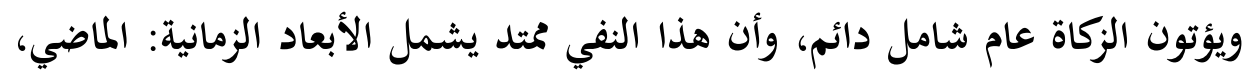
والحاضر، والمستقبل.

وهو ما أكده الإمام البيضاوي بقوله: 》امن آته وهو نفي الحخوف المستقبلي

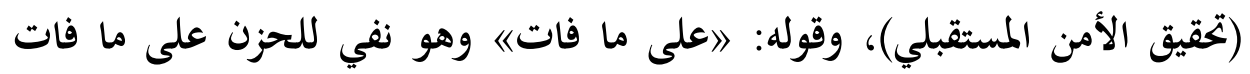
ليورث الشعور بالأمن في الحاضر والمستقبل.

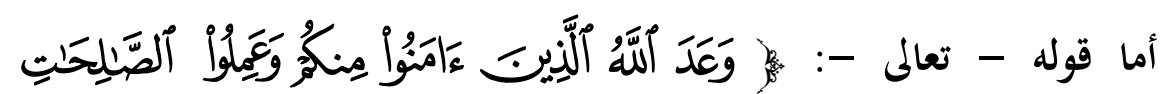

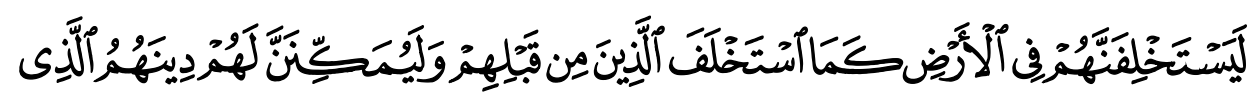

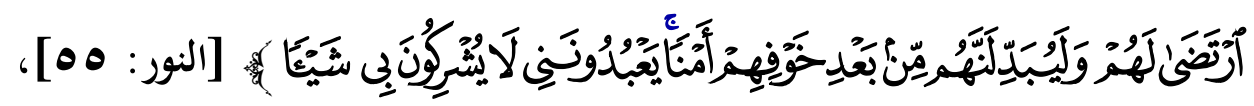
فهو يفيد نفي الحوف وإثبات الأمن بأبعاده المكانية.

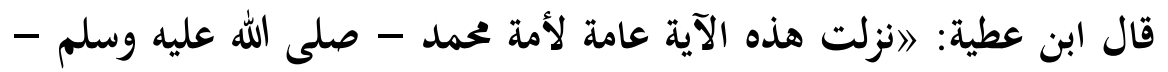

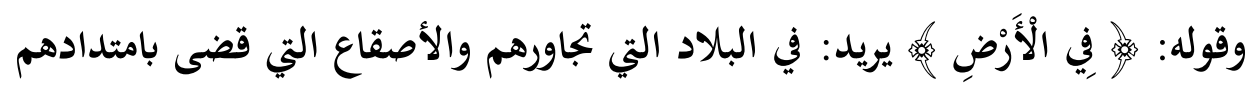

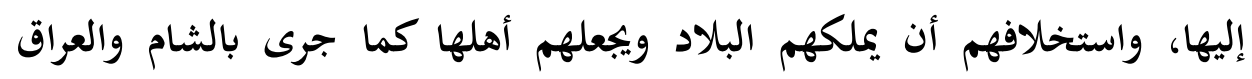
وخراسان《)

وقال الشوكاني: 》المعنى: أنه - سبحانه - يجعل لهم مكان ما كانوا فيه من

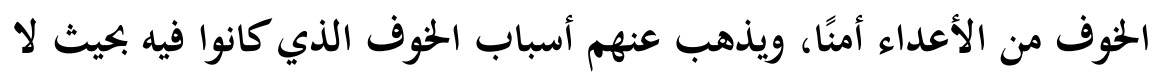

يخشون إلا اللهی) (1^). الآيات السابقة مجتمعة تؤكد حقيقة العلاقة الوثيقة بين الزكاة والأمن، فليس

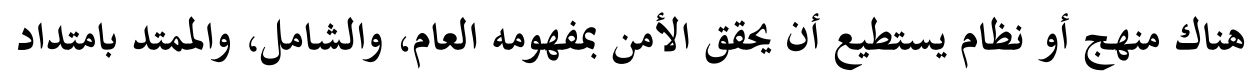

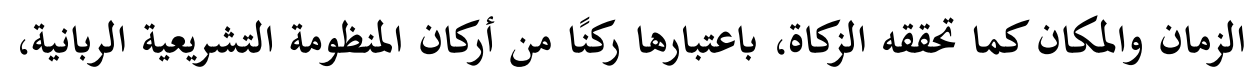


يقول د/سيد الهواري، في 》موسوعة الاستثمار): اوليس هناك أي نظام وضعي يهتم

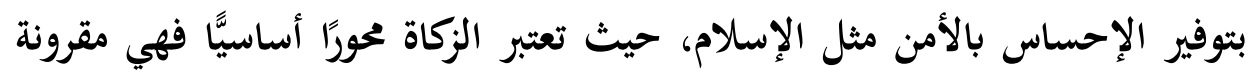

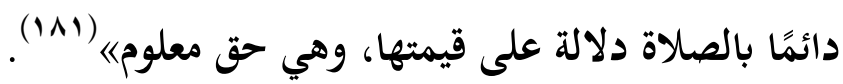

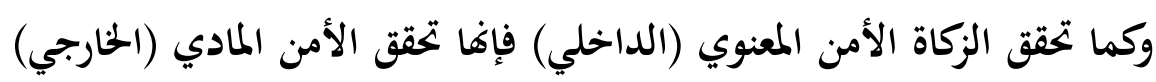

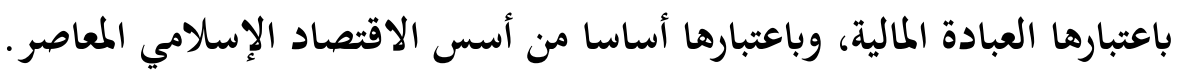

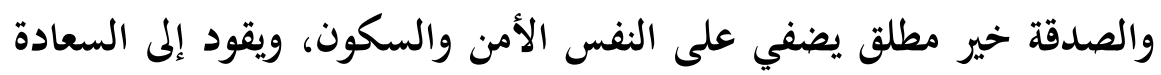

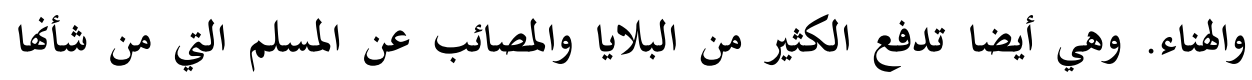

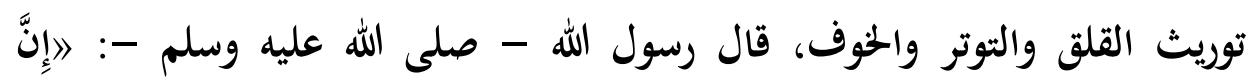

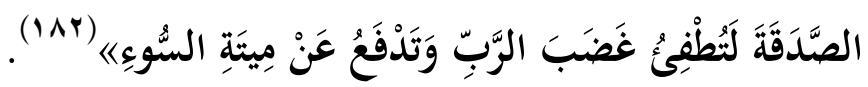

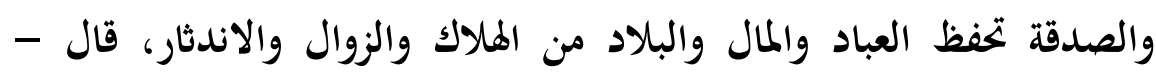

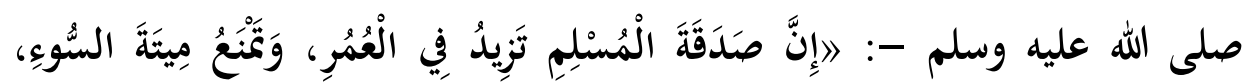

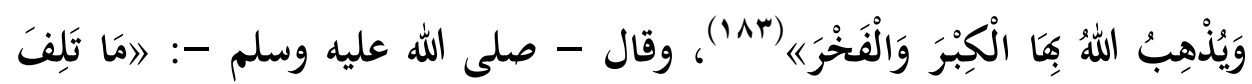

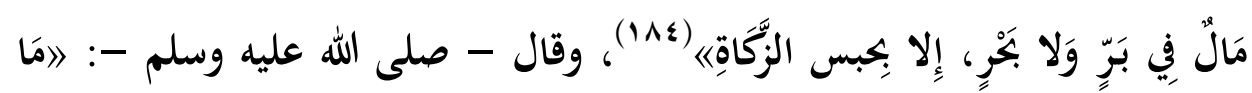

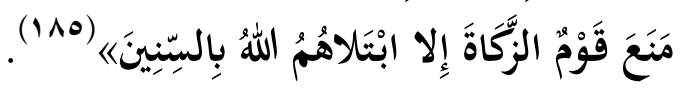

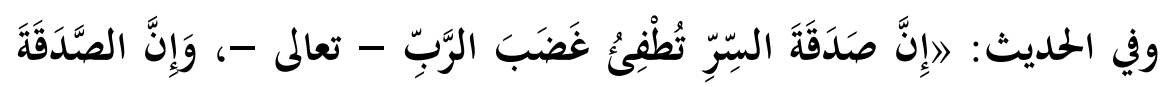

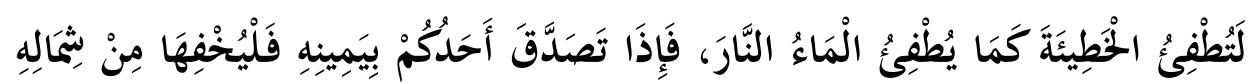

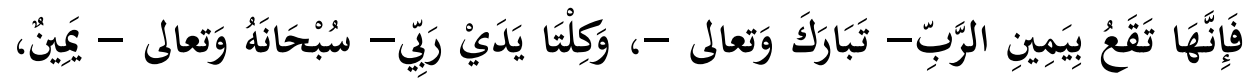

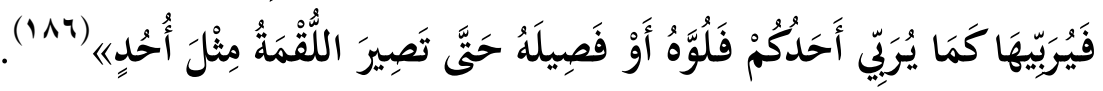

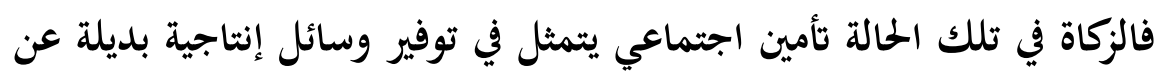
التي فقدها أرباب الحاجات مما يمكنهم من العمل والإنتاج وإعادة الكرة في البناء.

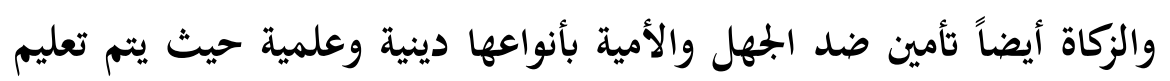
أبناء الفقراء والمساكين والأيتام وتدريبهم مما يؤهلهم لحياة إنتاجية كريمة لمم ولغيرهم. 
والزكاة تأمين ضد المرض؛ إذ تقوم مؤسسة الزكاة في الإسلام بتقديم خدمات علاجية للمرضي الذين لا يملكون مصاريف علاجهم وتقوم بتوفر اللازم من المشافي والأدوية التي تمول نفسها بنفسها لصالح علاج الفقراء والمساكين. وقد سبق أن ذكرنا قرار الندوة الفقهية الثالثة لبيت الزكاة الكويتي بشأن التمليك والمصلحة فيه ونتائجه؛ حيث جوز القرار إقامة مشروعات خدمية من مال الزكاة: كالمدارس والمستشفيات والملاجئ والمكتبات بحيث يفيد من خدمات هذه المشروعات مستحقو الزكاة دون غيرهم إلا بأجر مقابل لتلك الحخدمات يعود نفعه على المستحقين (INV) .

و تأمين ضد العجز والشيخوخة وذلك بكفالة كبار السن ممن لا عائل لهم، ومن الأمثلة على المشروعات الاستثمارية الزكوية التي تصب في مصلحة رعاية كبار

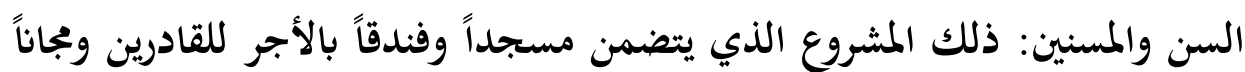
للمستحقين ومركز تدريب لحذدمة النزلاء والاستفادة من خبراقم، ومستوصفاً ومطعماً صغيراً ومغسلة، وقد تم هذا المشروع برعاية بنك ناصر الاجتماعي، وهو من أوائل

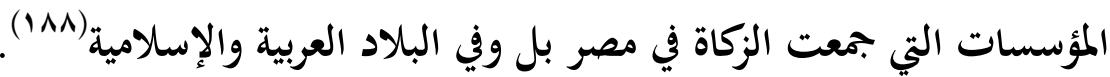
والحقيقة: أن هذه الأنواع التأمينية - المذكورة وما يشبهـها - لا تتميز بأفها الأسبق والأشمل فحسب بل هي تشريع معجز لم تتوصل البشرية لمثله حتى يومنا

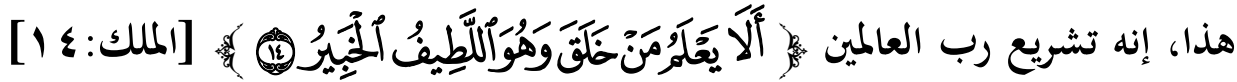
فهو دائم الصلاحية لكل زمن ومكان حتى قيام الساعة. المطلب السابع: مقصد الحرية ودفع العبودية. الزكاة من أهم آليات التشريع لتحرير العبيد والإماء وحفظ كرامتهم الإنسانية،

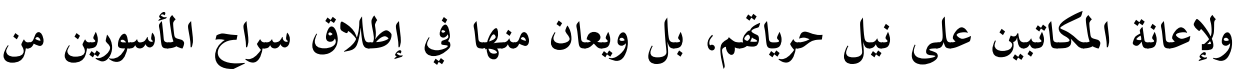

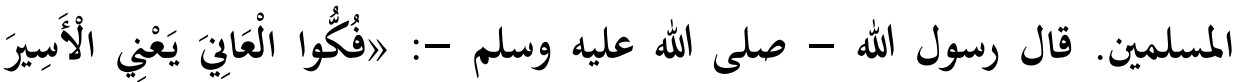




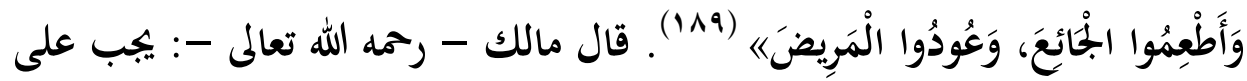
الناس فك أسراهم وإن استغرق ذلك أموالهم (a) (19). ومفهوم الحرية في الإسلام مفهوم واسع لا يقتصر على فك الرقاب وإطلاق سراح الأسرى وتحرير العبيد، بل يتعدى هذا كله ليشمل تحرير كافة شرائح الجمتمع من أواصر الضعف والعجز والفاقة والغرم، ولا يخفى على ذي لب ما للقيود المعنوية من آثار واضحة على تقييد الإنسان وكبت حريته وقتل إرادته ووأد همته. لقد أراد الإسلام أن يحرر الفقير والمسكين من ذل الحاجة والمسكنة واستعباد الفقر لمما، بل إن الإسلام حريص على كفاية الفقير على الدوام باستدامة الزكاة كل عام، وحريص على إغناء الفقير بإمداده بآلة حرفة يتقنها أو أداة مهنة يجيدها؛ ليتحرر من الفقر إلى الغنى، ومن الأخذ إلى العطاء، ومن الاستهلاك إلى الإنتاج.

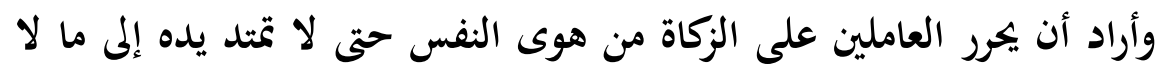

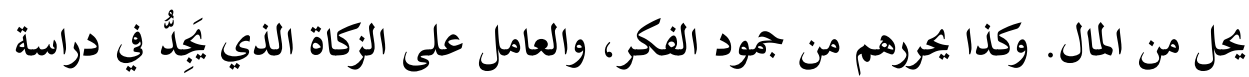
الواقع والإلمام بظروفه ومستجداته ويجتهد في تحقيق أفضل الوسائل ويبتكر أساليب لإغناء الفقراء ومحاربة البطالة له من الأجر ما قد يفوق المتصدق بالمال؛ لأن له أجر العامل على تحقيق الزكاة وأجر إغناء الفقراء والعمل على تنميتهم. وأراد أن يتألف قلوب ضعفاء الإيمان حتى يحررهم من الميل إلى الكفر أو

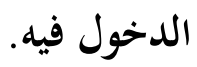
وأراد أن يحرر الغارمين من أصر الدَّيْن ومرارة الغُرْم، وأراد أن يحرِّرَ بالدعوة إلى الله العباد من عبودية غير الله إلى عبودية الله، وأراد أن يحرر بالجهاد في سبيل الله

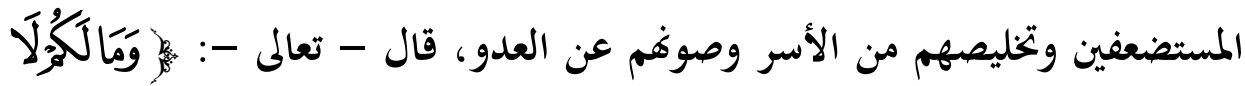

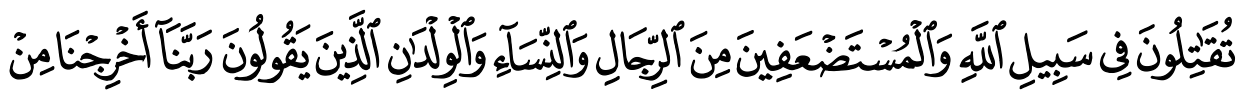




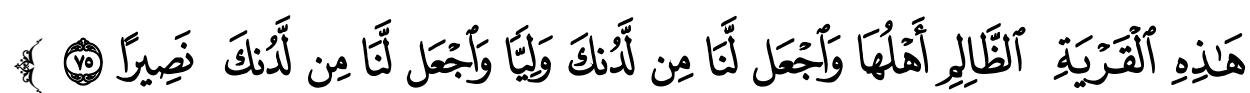
[النساء:[V0] وأراد أن يحرر أبناء السبيل من ذل الحاجة والعوز في السفر، وأن يفك أسرهم من غوائل الانقطاع وبشاعة الاغتراب. وأبمع المسلمون على أنه إذا نزل بالمسلمين حاجة وضرورة بعد أداء الزكاة

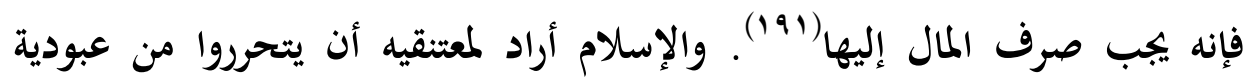

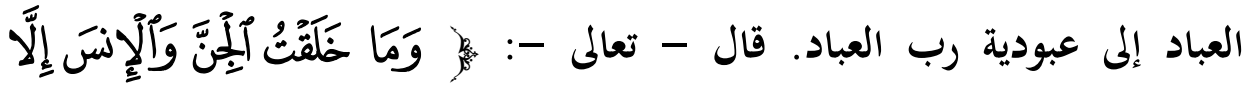

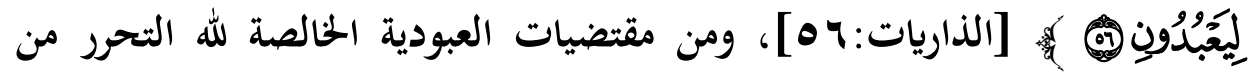
عبودية كل أحد إلا الله، فالأصل في الإنسان هو الحرية قال عمر بن الخطاب لعمرو

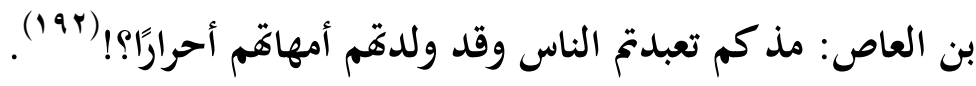
المطلب الثامن: مقصد الرحمة ودفع القسوة.

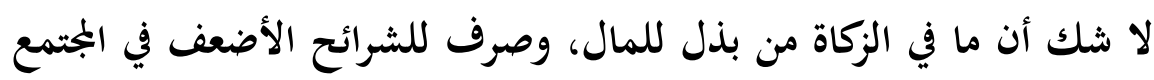
لتوفير سبل الحياة الكريمة لمم، ولدفع المشاق والأزمات التي يعانون منها كفيل بإحياء معاني الرحمة في نفس المزكين لأموالهم.

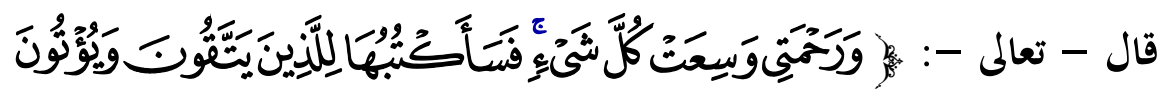

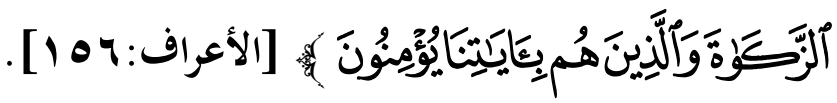

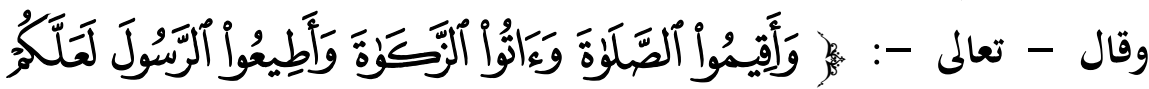

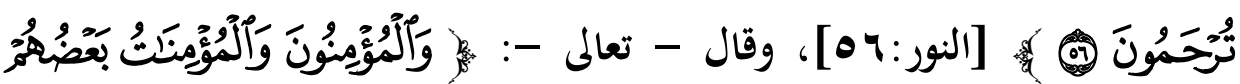

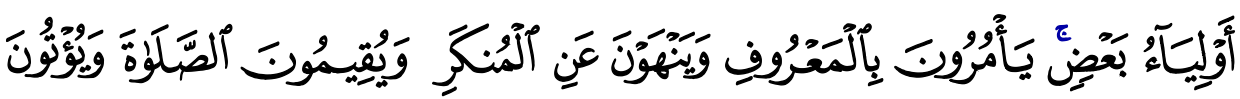

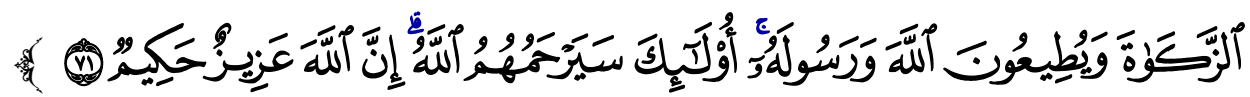

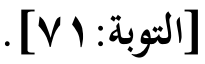


والزكاة من أهم أسباب الرمة؛؛ لما تنمِّيه في القلب من الشعور بالعطف والرقة

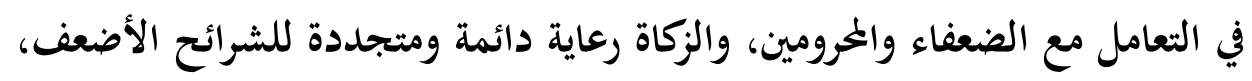

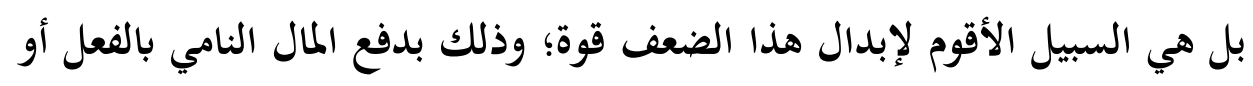
التقدير لهذه الثرائح الضعيفة لتخرج به من أسباب ضعفها، أو لتعمل في تنميته من هن الإلدال

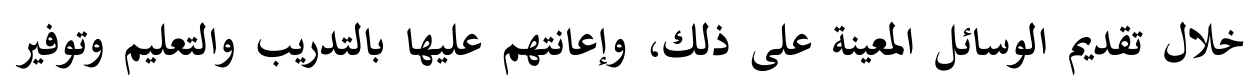
أدوات الحرف الملائمة، أو تقديم القروض الحسنة الحالية من الربا إذا دَعَبِ الضرورة لذلك.

والزكاة رحمة ينعم بجا المؤمن، وتراحم يسود في الجُتمع ويعم جميع أفراده، والزكاة مجلبة للرحمة بأن تعم جميع الحلائق.

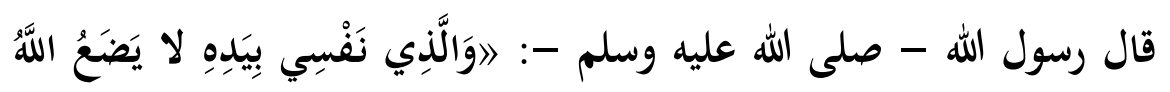

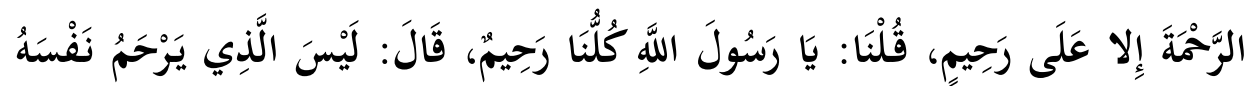

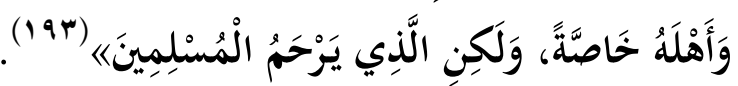

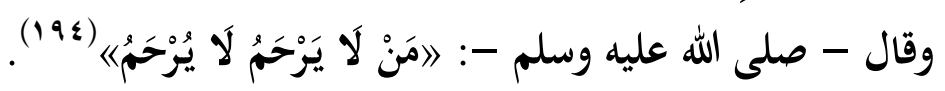

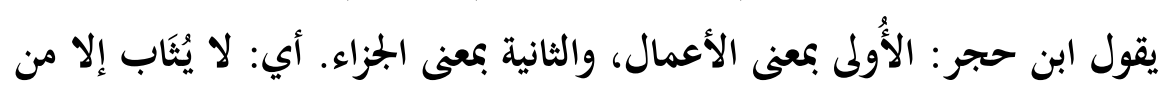

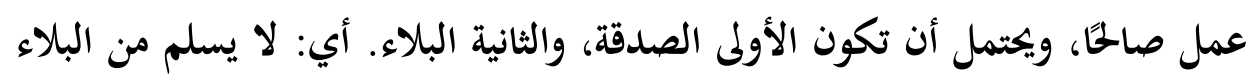

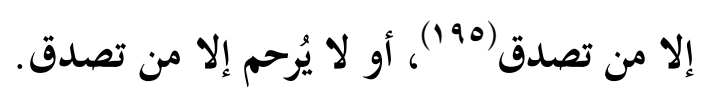
قال أبو محمد ابن حزم: ومن كان على فضلة ورأى أخاه جائعًا عريانًا ضائقًا

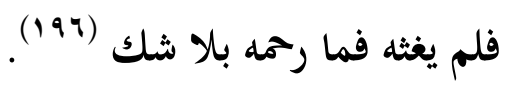
وبملة القول: إن الزكاة رحمة للمؤلفة قلوكمم؛ لتأليفهم على الإسلام وهدايتهم

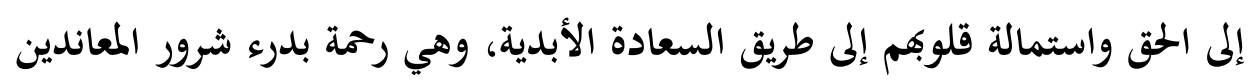
من أصحاب النفوذ عن المسلمين والمجتمعات المسلمة. والزكاة رحمة للعبيد والإماء بعتقهم وبتحرير الأسرى، ثم بإعادة تأهيلهم للحياة والإنتاج. 
والزكاة رحمة بقضاء حوائج الملدينين وبسداد الديون عنهم وبإعادقم للإنتاج.

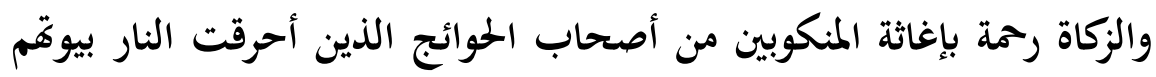
وأهدمها السيل أو دمرها الزلزال.

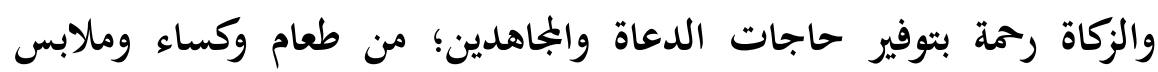

$$
\text { وأدوات تعينهم على مهامهم لتحقيق الأمن والسلام. }
$$

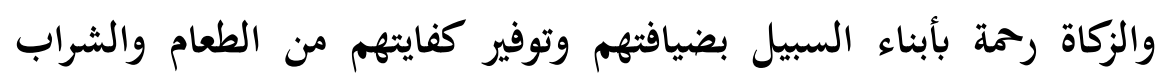
والمسكن ووسائل الانتقال لإعادقم لأوطافم.

وهي رحمة للأمة بما تحققه من تواصل إنساني بين فئات الجُتمع الغنية والفقيرة

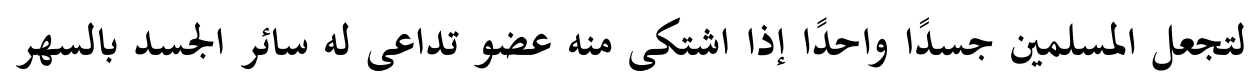

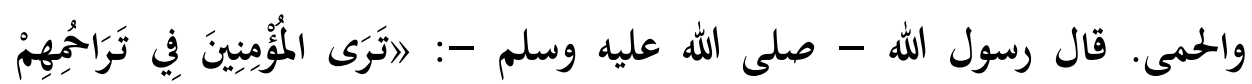

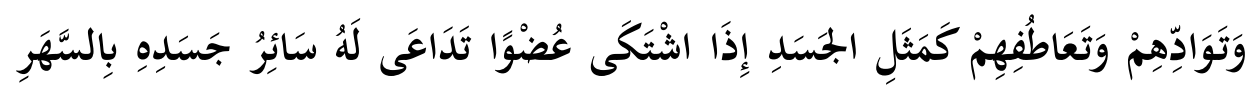

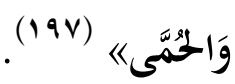




\section{الخاتمة، وأهم النتائج}

في الحتام أحمد الله أن منَّ علي بإنجاز هذا البحث، والذي ألخص نتائجه فيما

1- معظم مزالق الاجتهادات المعاصرة مردها إلى الجهل بمقاصد الشريعة ومراميها.

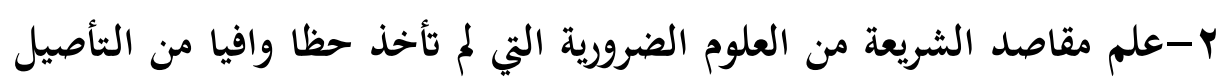
والتنظير. r- إن العبودية الخالصة لله هي مقصد المقاصد وغاية الغايات، وكل المقاصد العامة والخاصة، الكلية والجزئية تدور في فلكها.

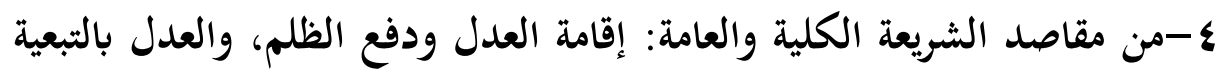

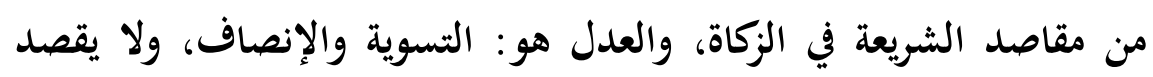

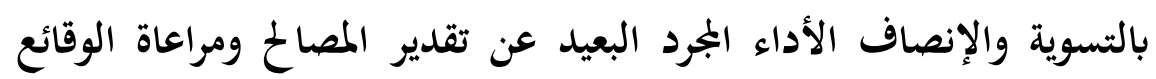
والظروف والأسباب، بل يقصد بها ما كان في سبيل إحقاق الحق.

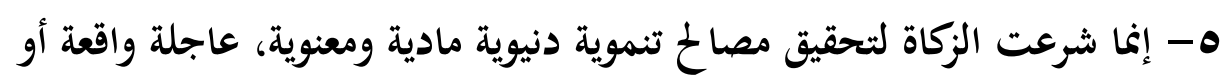
متوقعة، و مصالح أخروية آجلة متحققة.

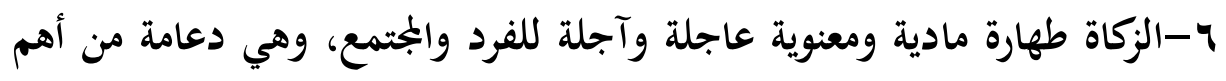

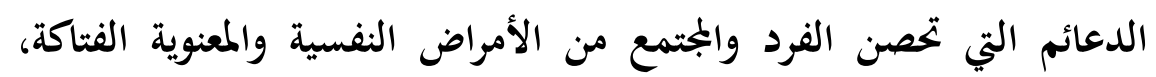

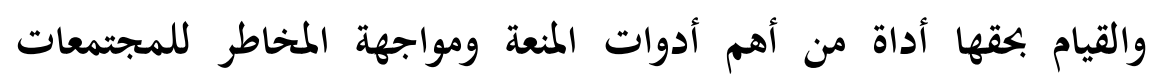
المسلمة.

V-من مظاهر القوة في التشريع الزكوي: كفاية الفقراء والمساكين وتعليمهم وأبنائهم

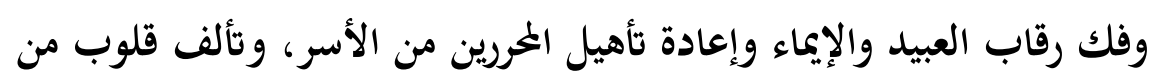

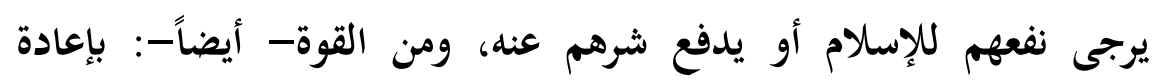

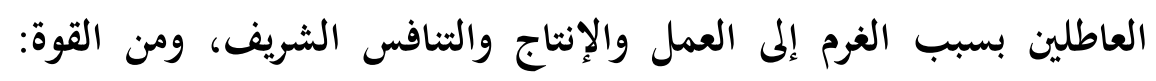


إعطاء الذين يرابطون في الثغور وحدود الأعداء؛ لما يرجى من دفاعهم ومايتهم لمن هو دوفم من المسلمين.

1- إن إيتاء الزكاة يحقق للمسلم الأمن بمفهومه الشامل: الأمن الداخلي،

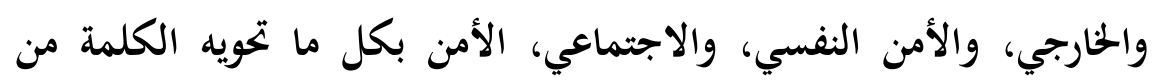
معان: الأمن بأبعاده الزمانية والمكانية.

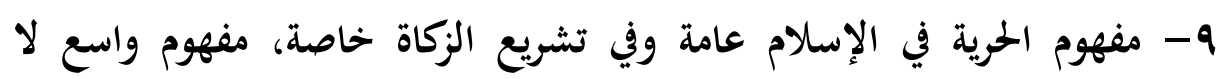

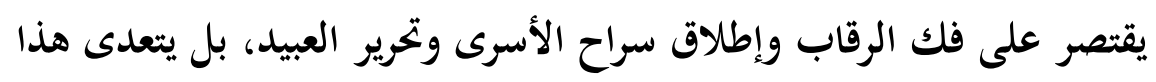

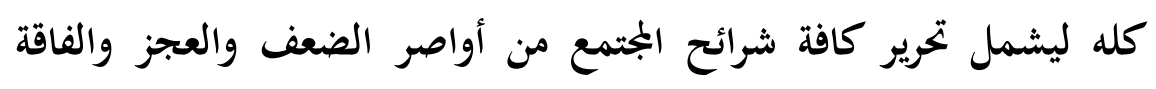

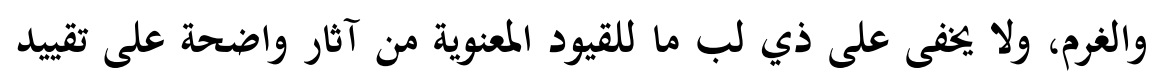

$$
\text { الإنسان وكبت حريته وقتل إرادته ووأد همته. }
$$

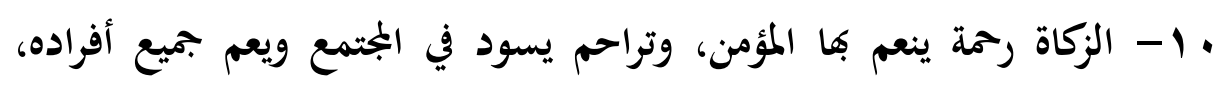
والزكاة مجلبة للرحمة بأن تعم جميع الحلائق. 


\section{فهرس المصادر والمراجع}

1- أبحاث فقهية في قضايا الزكاة المعاصرة، د. محمد سليمان الأشقر و آخرون، طبعة دار النفائس.

r- أحكام القرآن، الإمام حجة الإسلام. أبو بكر أحمد بن علي الرازي الجصاص

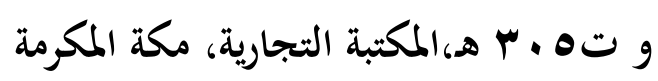

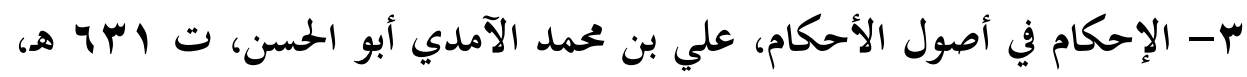

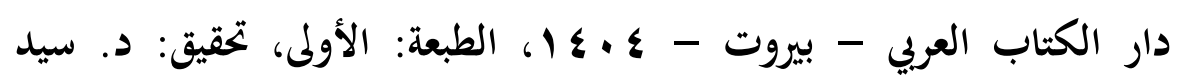

\section{الجميلي.}

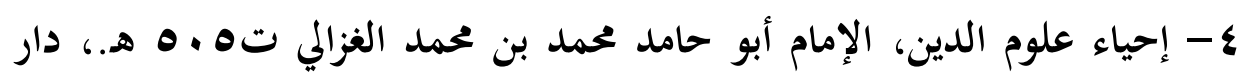
القلم-بيروت، مراجعة الشيخ: عبد العزيز السيروان.

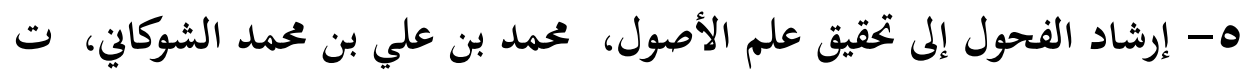

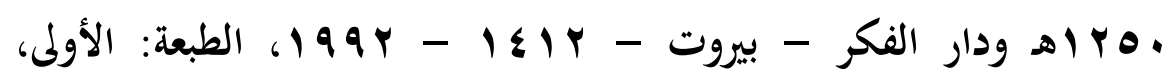

$$
\text { تحقيق: محمد سعيد البدري. }
$$

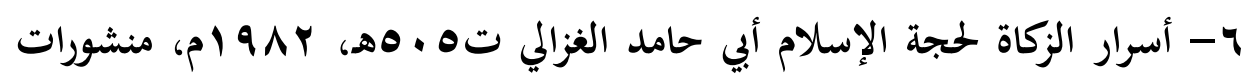

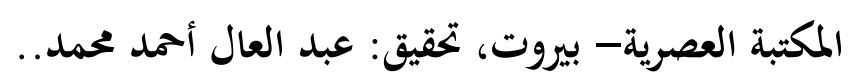

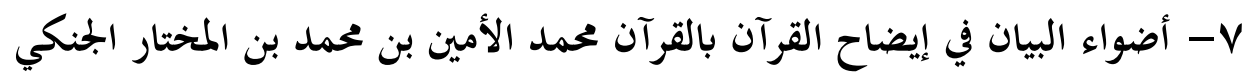

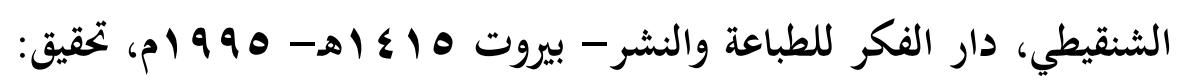

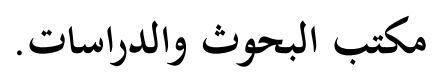

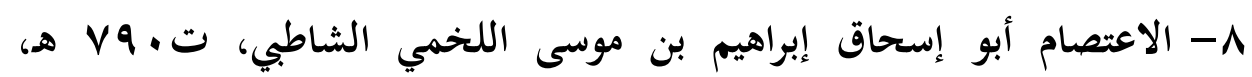
المكتبة التجارية،مصر.

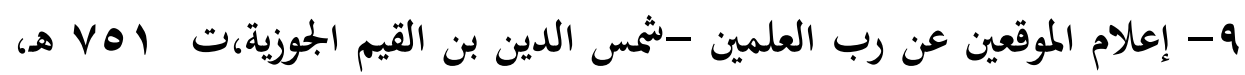

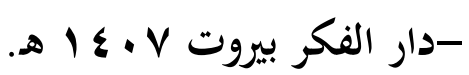




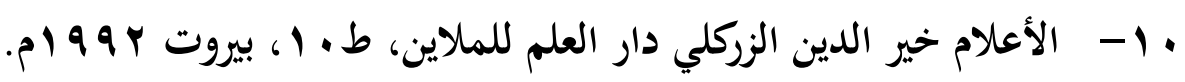
11- التعريفات: علي بن حممد بن علي الجرجاني، دار الكتاب العربي - بيروت - 0 • ع 1، الطبعة: الأولى، تحقيق: إبراهيم الأبياري.

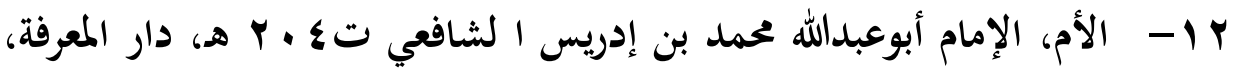
بيروت.

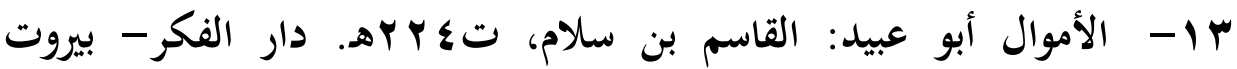

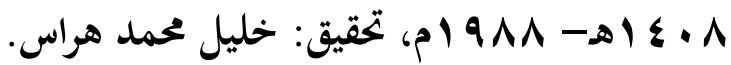

ع ا- - أنوار التنزيل وأسرار التأويل، لأبي سعيد عبد الله بن عمر بن محمد الشيرازي البيضاوي تهیף هـ. دار الفكر العربي- بيروت.

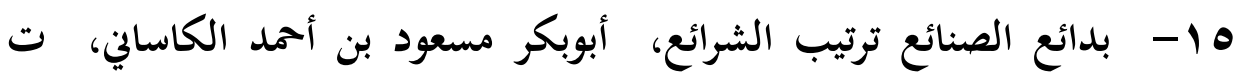
OAV هـ هـ دار الكتب العلمية، بيروت.

7 ا - البرهان في أصول الفقه، عبد الملك بن عبد الله بن يوسف الجويني أبو

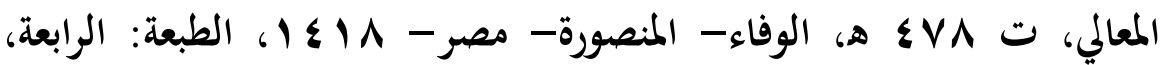

تحقيق: د. عبد العظيم محمود الديب.

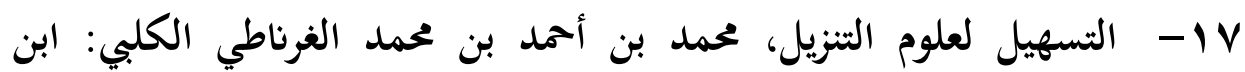

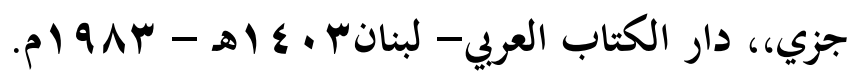

1 ا - تفسير السعدي، المعروف بتيسير الكريم الرحمن في تفسير كلام المنان الشيخ

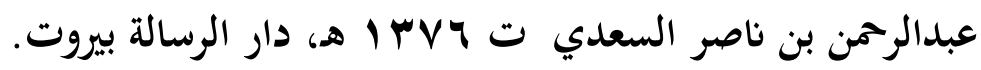
9 1 - تفسير الطبري، 》جامع البيان عن تأويل آي القرآن/ محمد بن جرير الطبري

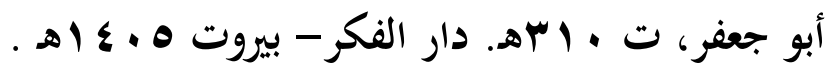
• † - تفسير القرآن العظيم، إسماعيل بن عمر بن كثير الدمشقي أبو الفداء، ت ع هـ بيروت. 
ا إ- التفسير الكبير أو مفاتيح الغيب، فخر الدين محمد بن عمر التميمي الرازي

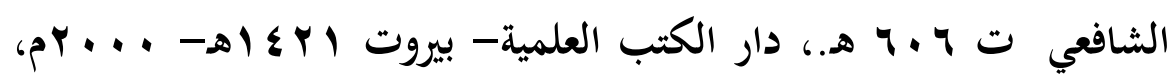
.16

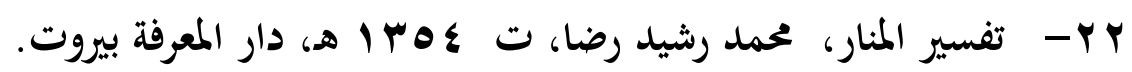
بr أب- الثروة في ظل الإسلام، د البهي الخولي، مكتبة القاهرة.

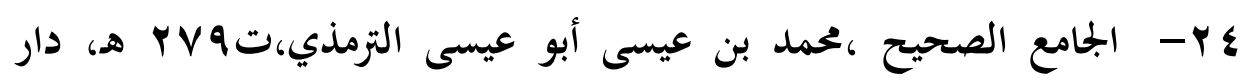

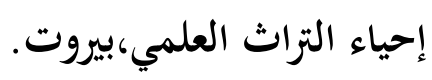

هـ- الجامع الصحيح المسند من حديث رسول الله، أبوعبدالله محمد بم إسماعيل

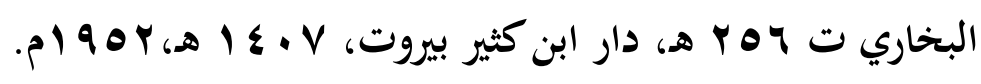

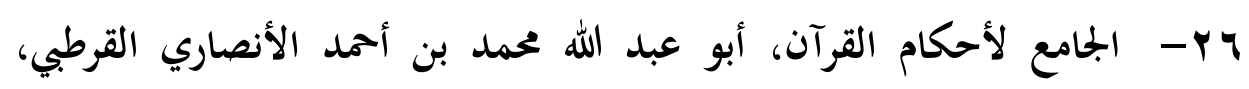

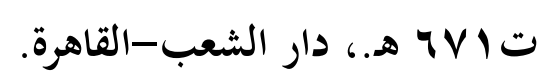

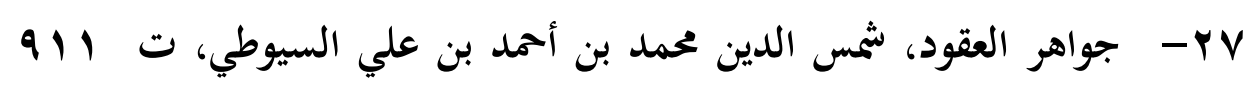

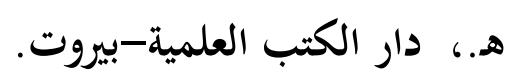

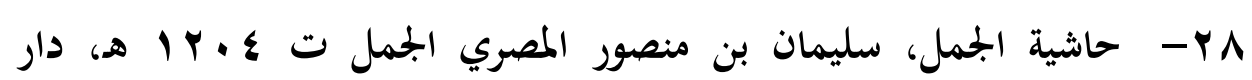
الفكر.

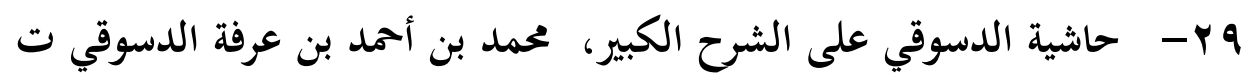
.

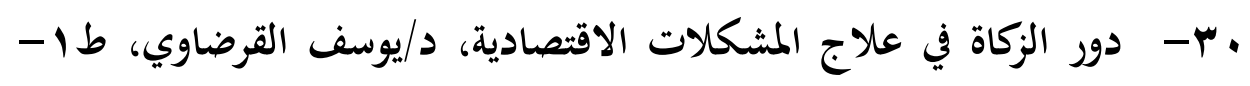

$$
\text { الج }
$$

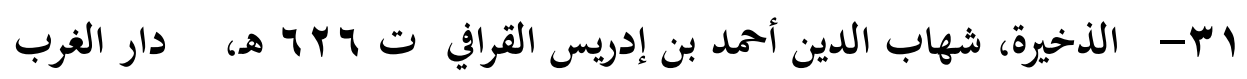

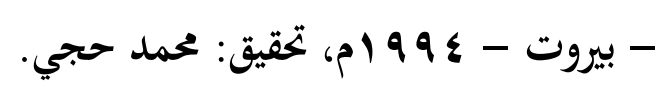

r T- رد الختار على الدر المختار في شرح تنوير الأبصاره (حاشية ابن عابدين)،

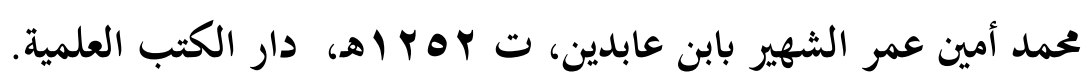


بr- روضة الناظر وجنة المناظر: موفق الدين عبد الله بن أحمد ابن قدامة.ت • ب آ هـ، الدار السلفية . .

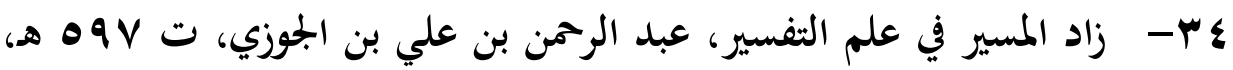

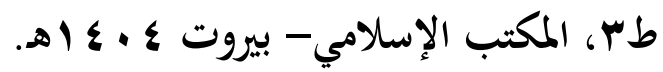

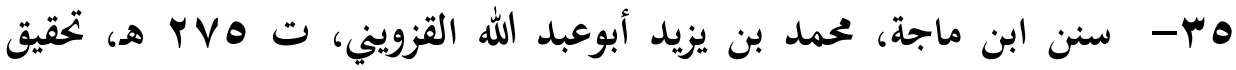

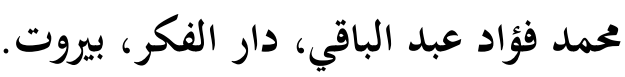

דا - سنن أبوداود، سليمان بن الأشعث بن إسحاق بن بشير الأزدي السجستاني، ت هV P هـ، دار الفكر سوريا

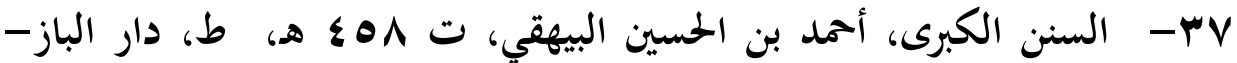

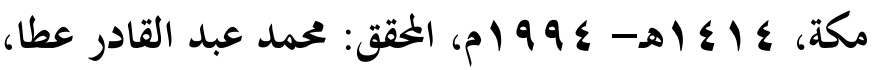
مب- السياسة الشرعية في إصلاح الراعي والرعية، أحمد بن عبد الحليم بن تيمية،

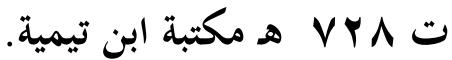

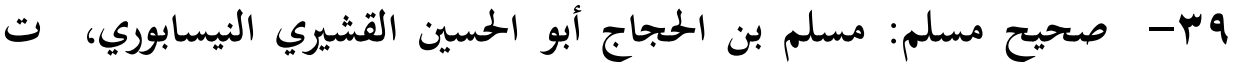
الآ هـ، دار إحياء التراث العربي - بيروت، تحقيق: محمد فؤاد عبد الباقي.

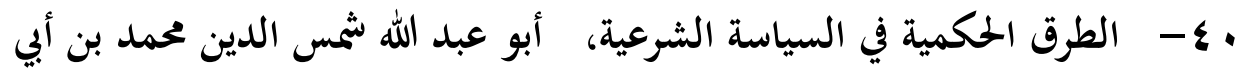

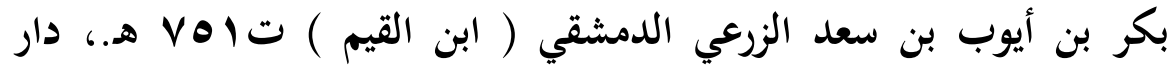

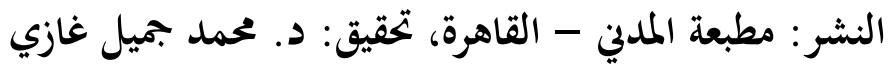

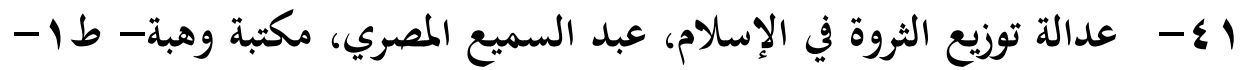
.8) $\varepsilon \cdot 7$ ץ ؟ - فتح القدير الجامع بين فني الرواية والدراسة من علم التفسير، محمد بن علي

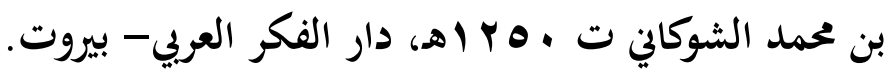

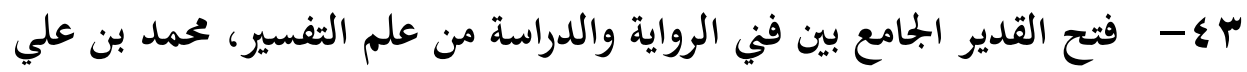

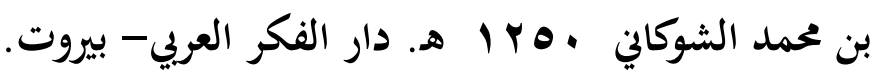


؟ §- الفروع، لابن مفلح: ثمس الدين أبو عبد الله محمد بن مفلح المقدسي،

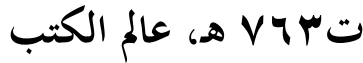

هـ- الفروق أو أنوار البروق في أنواء الفروق (مع الهوامش )، أبو العباس أحمد بن إدريس الصنهاجي القرافي، ت عـي هـ دار الكتب العلمية - بيروت 11 إ اهـ - 99191م، الطبعة: الأولى، تحقيق: خليل المنصور.

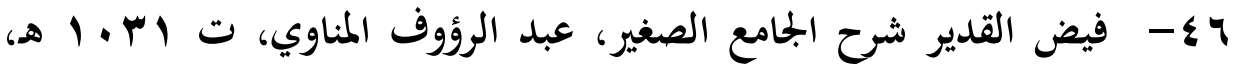

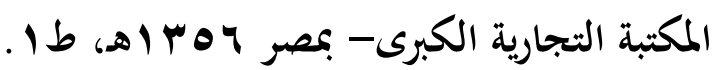

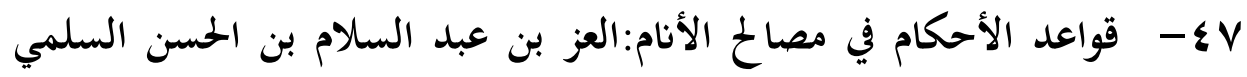
الدمثقي، عز الدين: الملقب بسلطان العلماء، ت . . 7 هـ. دار أم القرى.

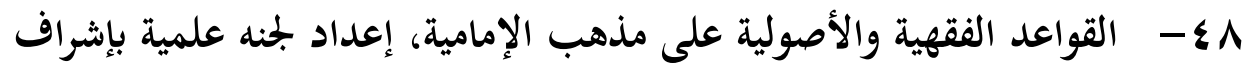
محمد علي التسخيري.

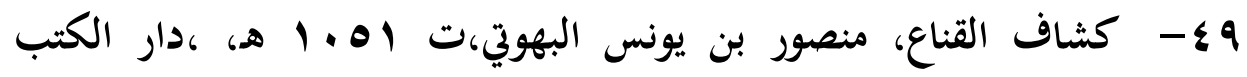

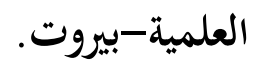

•ـ- كليات النور، بديع الزمان سعيد النورسي، سوكة سوز ليز، استانبول،

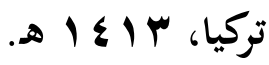

اOه- لسان العرب، مجمد بن أبي الغر مكرم بن علي بن أمد الحزرجي المعروف بابن منظور ت VII هـ دار صادر، بيروت.

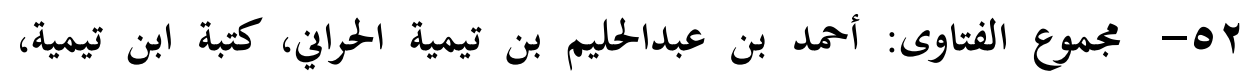
الطبعة: الثانية، تحقيق: عبد الرحمن بن محمد.

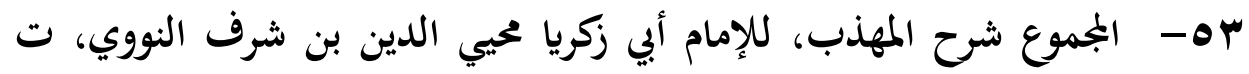
TVI هـ، مكتبة الإرشاد- جدة، تحقيق: محمد نجيب المطيعي. 


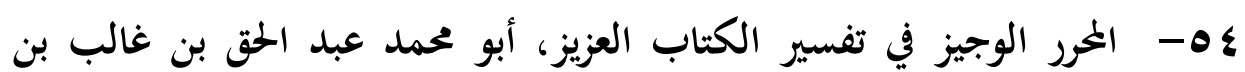

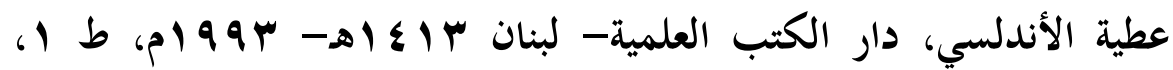
تحقيق: عبد السلام عبد الشافي محمد.

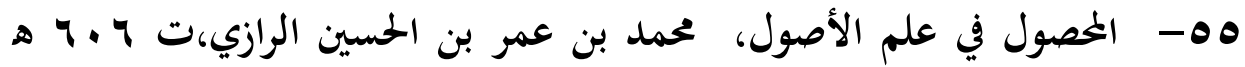

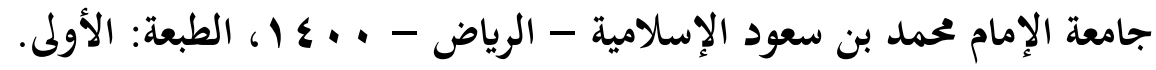

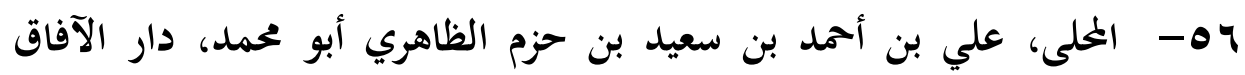

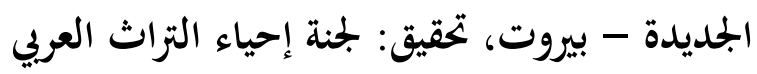
-OV

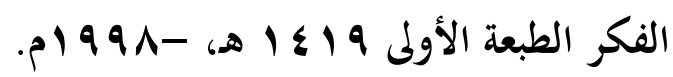

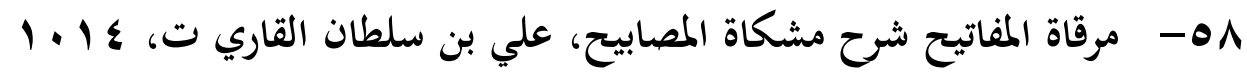

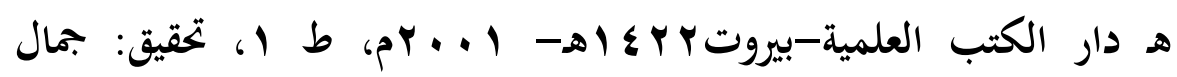
عيتاني.

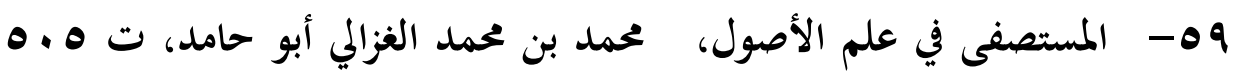

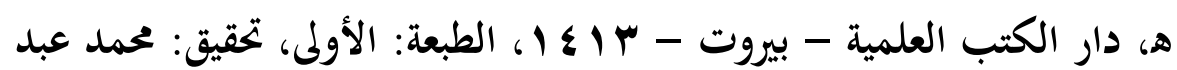
السلام عبد الشافي.

• צ- - مطالب أولي النهى في شرح غاية المنتهى، الشيخ مصطفى بن سعدة بن عبده الرحيباني، ت ب ع ب اهـ، المكتب الإسلامي.

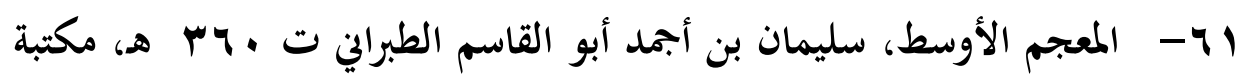
المعارف الرياض، تحقيق د محمد الطحان. ب ب- المقاصد الشرعة ودورها في استنباط الأحكام، مجلة المسلم المعاصر، العدد المعان

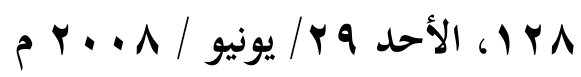
با7- مقاصد الشريعة الإسلامية، محمد الطاهر ابن عاشور،تحقيق و دراسة محمد

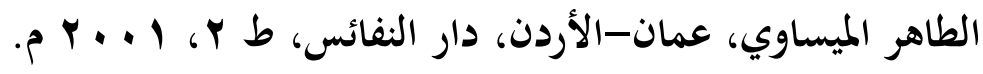




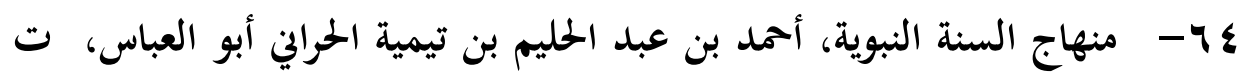

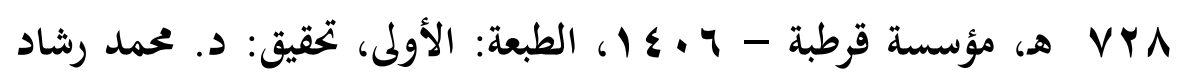

سالم.

هـ- المواد العلمية لبرنامج التدريب على تطبيق الزكاة، في الجُتمع الإسلامي،

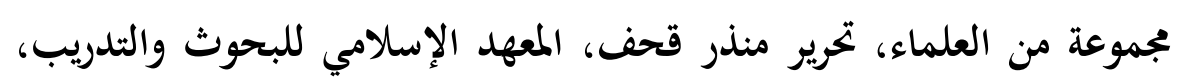
البنك الإسلامي للتنمية، جدة السعودية.

צ دار الكتب العلمية بيروت، شرحه وخرج أحاديثه فضيلة الشيخ عبد الله دراز.

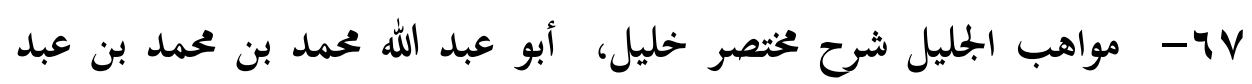

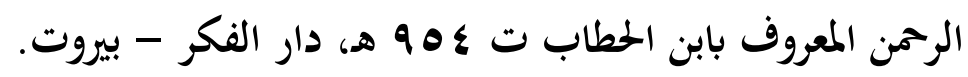
1 \- الموسوعة الفقهية لوزارة الأوقاف والثئون الإسلامية الكويتية.

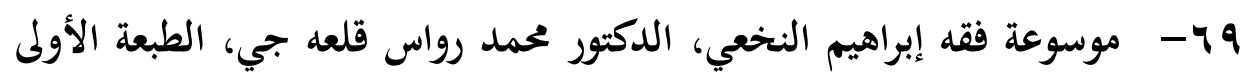

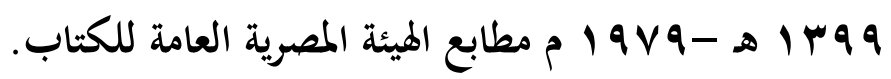
•

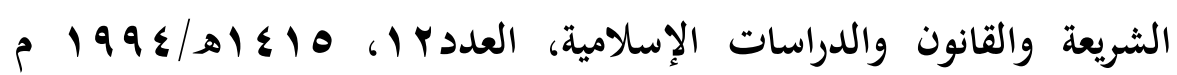
جامعة قطر. 
الهوامش

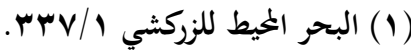

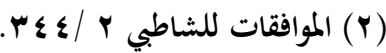

(Y) انظر : القواعد الفقهية والأصولية على مذهب الإمامية / V V / إعداد لجنسه علمية بإشراف محمد علي التسخيري.

( ) أحمد الريسولي: المقاصد الثرعة ودورها في استنباط الأحكام، مجلة المسلم المعاصر، العدد ^ ب ا الأحسد

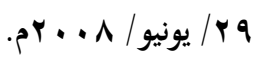

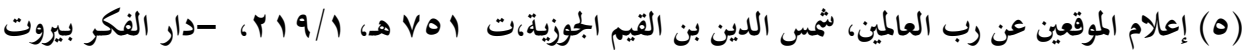

ه $1 \varepsilon \cdot V$

(ד) لسان العرب《 مادة (قصد)، مجمد بن أبي الغر مكرم بن علي بن أحمد المخزجي المعروف بابن منظور ت

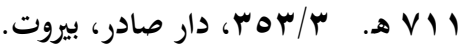

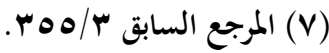

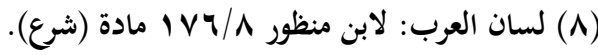

(9) أحمد بن عبد الحليم بن عبد السلام بن عبد الله بن أبي القاسم الحرابي الدمشقي الحنبلي، أبو العباس: تقي

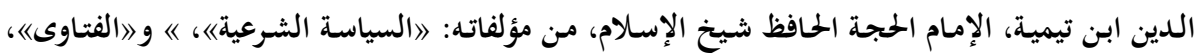

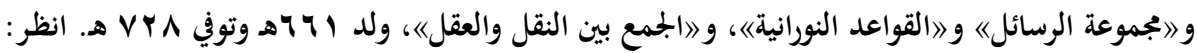

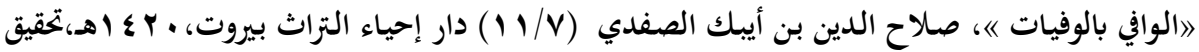
أحمد الأرناؤوط.

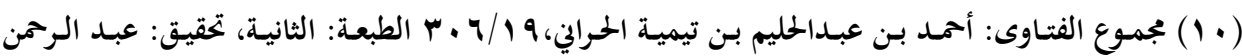
بن محمد

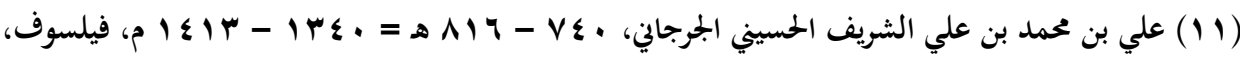

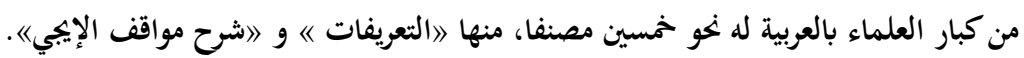

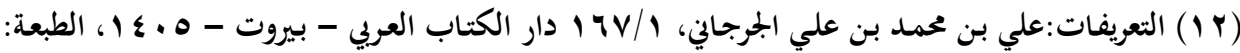
الأولى، تحقيق: إبراهيم الأبياري.

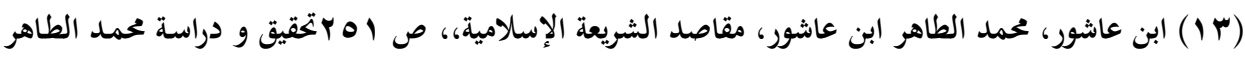

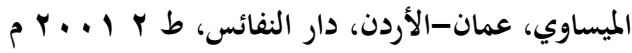

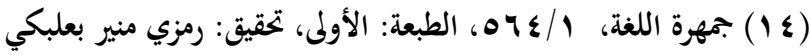


(0) علال الفاسي، مقاصد الثريعة ومكارمها، د.م، مكتبة الواحدة العربية والدار البيضاء، د.ط، د.ت، ص

( ( 1) الحـادمي، نورالدين بـن مختـار، الاجتهاد المقاصـدي حجيته ضـوابطه بجالاته، كتاب الأمة، قطر، وزارة

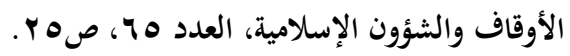

(الدريني، محمد فتحي، المناهج الأصولية في الاجتهاد بالرأي في التشريع الإسلامي، بيروت-لبنان، مؤسسة

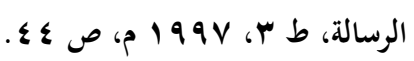

(1) الريسولي، أحمد، نظرية المقاصد عند الإمام الشاطبي، الرياض-السعودية، الدار العالمية للكتاب الإسلامية،

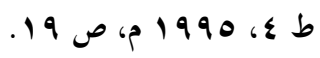

(9 (1) إبراهيم بن موسى بن محمد اللخمي الغرناطي الشهير بالثاطبي، أصولي حافظ من أهل غرناطة، من أئمة

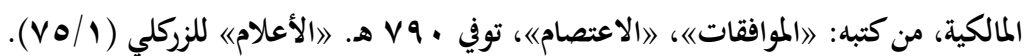

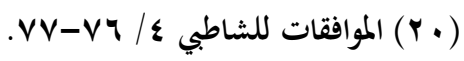

(Y) ابن قيم الجوزية: محمد بن أبي بكر بن أيوب بن سعد الزرعي الدمشقي، أبو عبد الله شمس الدين: من أركان

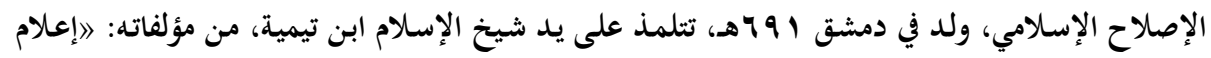

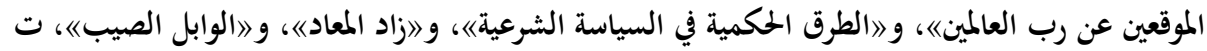

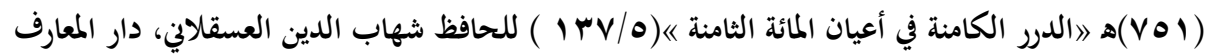

$$
\text { العثمانية، حيد اباد. }
$$

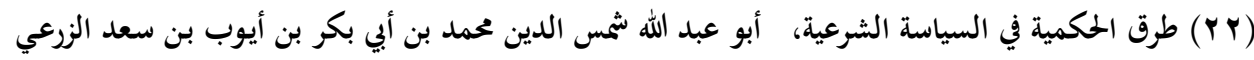
الدمشقي ( ابن القيم) / /ه، دار النشر: مطبعة المدلي - القاهرة، تحقيق: د. محمد جميل غازي.

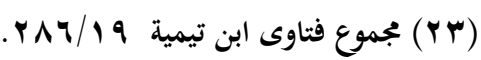

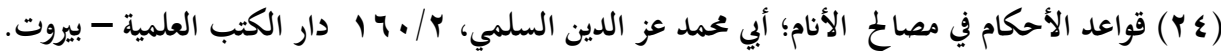

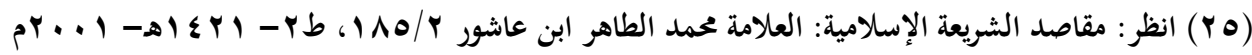

$$
\text { دار النفائس. }
$$

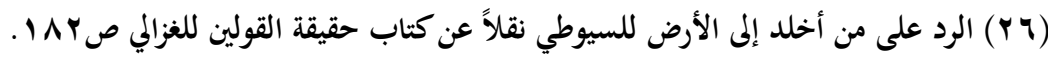

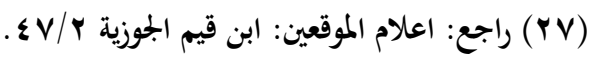

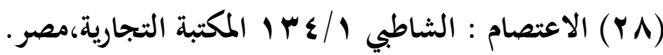

( ( ) لشهاب الدين أحمد بن إدريس بن عبد الرحمن الصنهاجي المالكي الفقيه الأصولي، من مصنفاته الفروق،

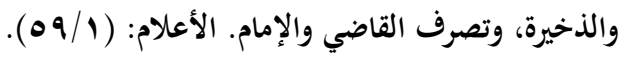

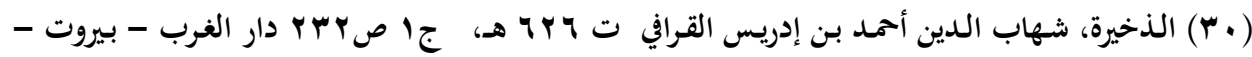

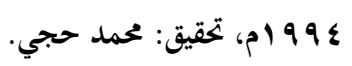

(اسM) عوامل الثهود الحضاري: عبد الججيد النجار صه ع دار الغرب الإسلامي. 
(Tr) صحيح البخاري: كتاب الاعتصام بالكتاب والسنة، باب إثم من دعا إلى ضلالة.

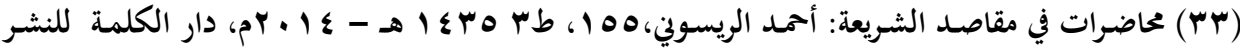

$$
\text { والتوزيع - القاهرة. }
$$

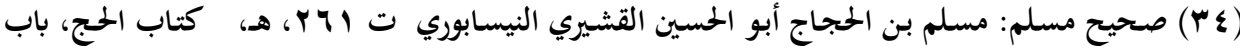
نقص الكعبة وبنائها، دار إحياء التراث العربي - بيروت، تحقيق: محمد فؤاد عبد البادي الباقي.

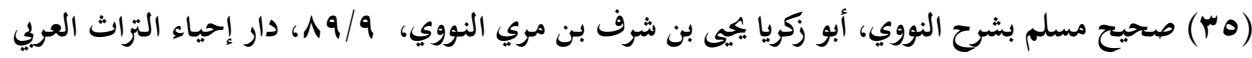

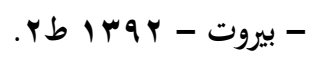

(דr) إعلام الموقعين عن رب العالمين: أبو عبد الله شمس الدين محمد بن أبي بكر بن أيوب بن سعد الزرعي

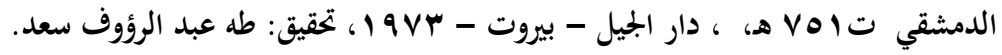
(rV) صحيح مسلم كتاب الإيمان، باب الأمر بقتال الناس حتى يقولوا لا إله إلا الله محمد رسول الله.

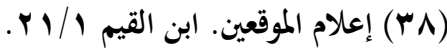

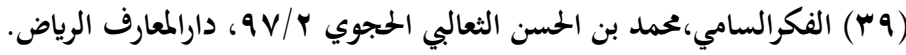

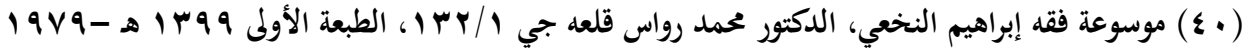
م مطابع الميئة المصرية العامة للكتاب.

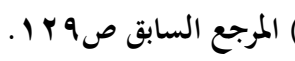

(ץ) عبد الله بن أحمد بن قدامة المقدسي الحنبلي، أبو محمد، موفق الدين: فقيه من أكابر الحنابلة، ولد في

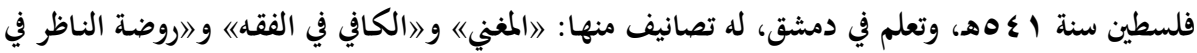

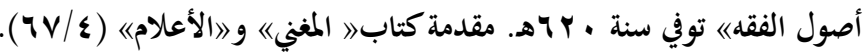

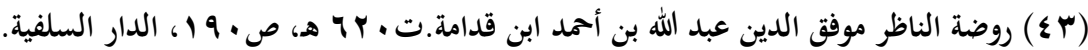

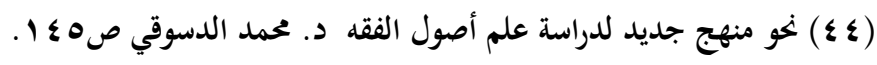

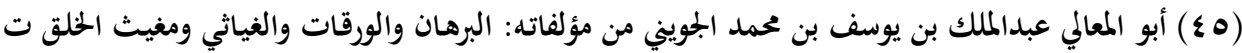

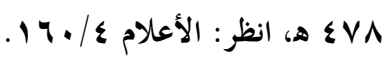

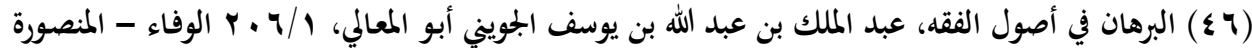
- مصر - 1 إ ا، الطبعة: الرابعة، تحقيق: د. عبد العظيم محمود الديب.

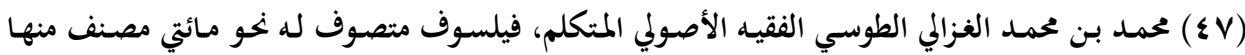

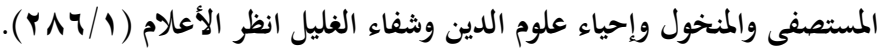

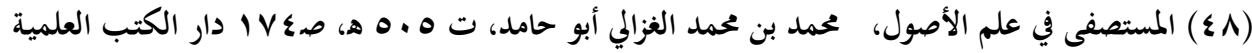
- بيروت - با إ ا، الطبعة: الأولى، تحقيق: محمد عبد السلام عبد الشافي. 
( • (ه) محمد بن عمر بن الحسن بن الحسين التميمي البكري، أبو عبد الله فخر الدين الرازي: الإمام المفسر،

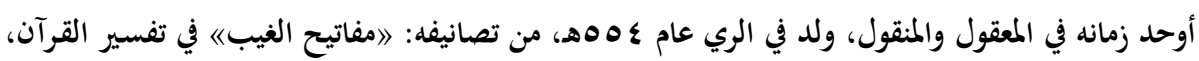

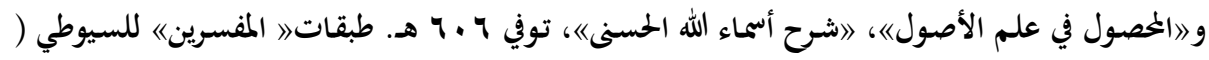

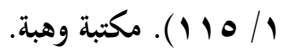

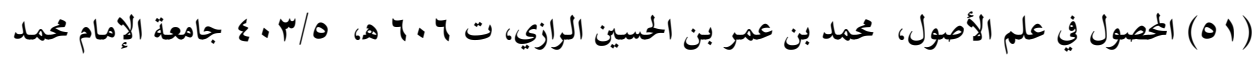
بن سعود الإسلامية - الرياض - . . ع 1، الطبعة: الأولى، تحقيق: طه جابر فياض العلوالي.

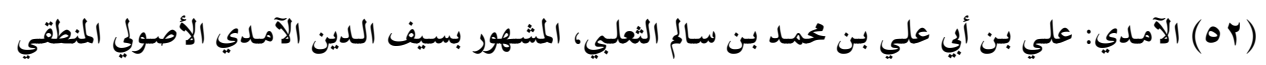

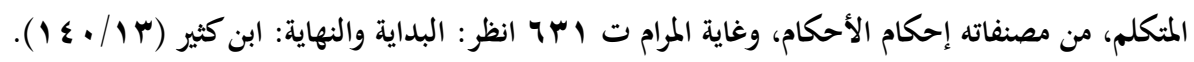

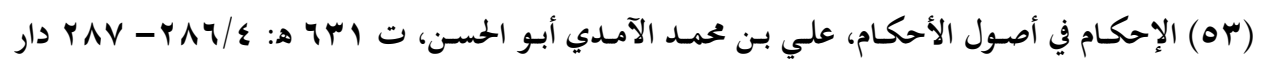
الكتاب العربي - بيروت - ع • ع ا، الطبعة: الأولى، تحقيق: د. سيد الجميلي.

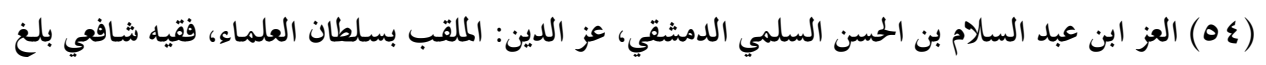

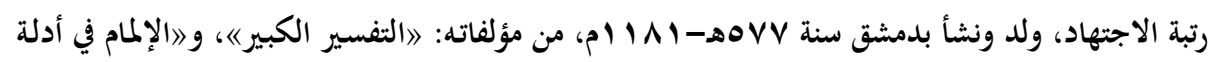

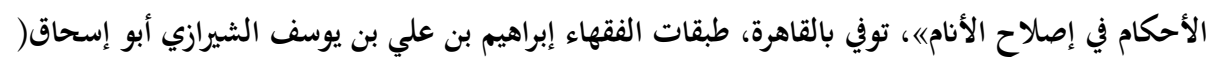

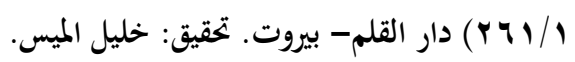

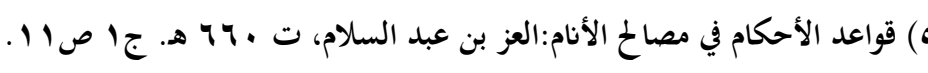

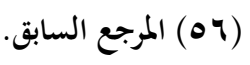

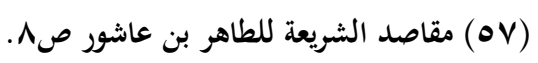

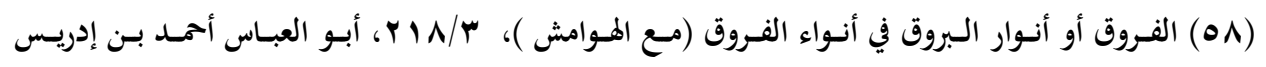

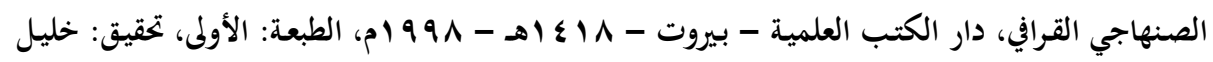

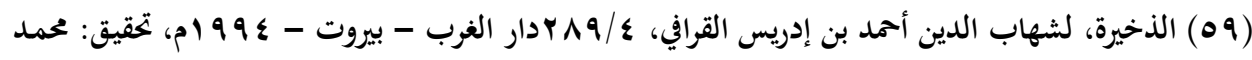
( • (7) محمد بن علي بن محمد بن عبد الله الشوكاني: فقيه مجدد مجتهد من كبار علماء اليمن، نشأ بصنعاء وولي

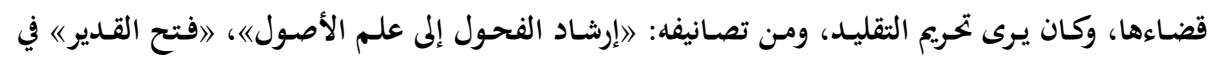

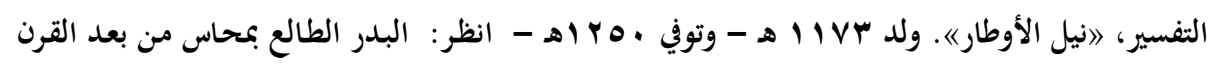

$$
\text { السابع -ددار المعرفة بيروت. }
$$

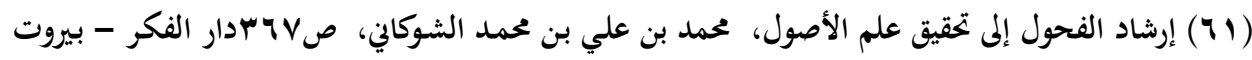

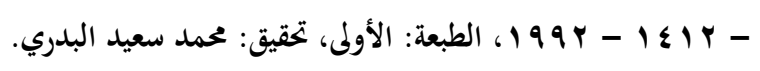

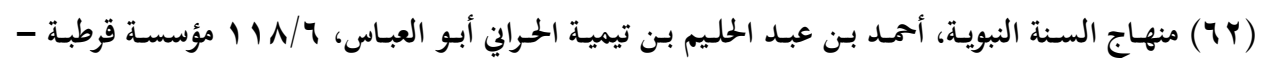

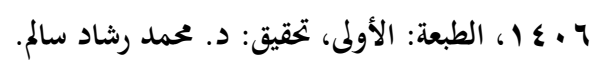


(Tr) ابن قيم الجوزية: محمد بن أبي بكر بن أيوب بن سعد الزرعي الدمشقي، أبو عبد الله ثمس الدين: من أركان

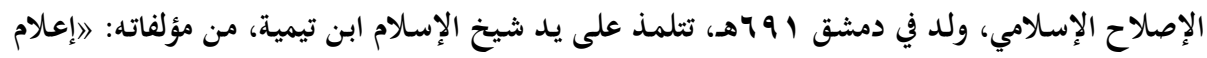

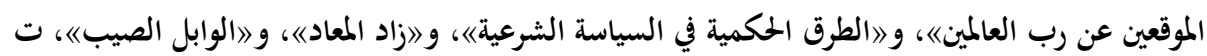

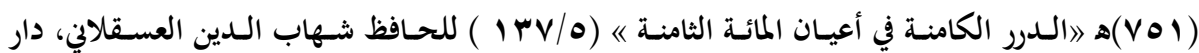

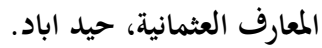

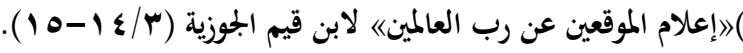

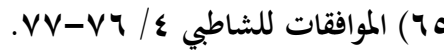

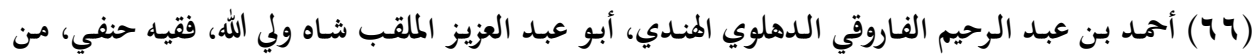

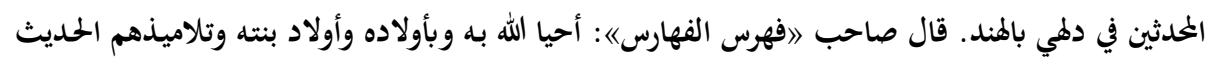

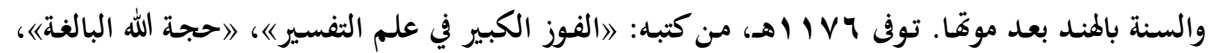

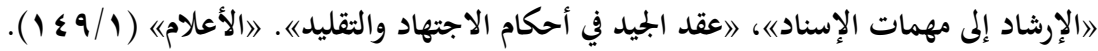

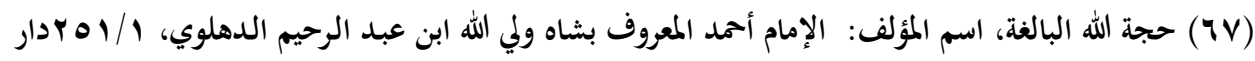

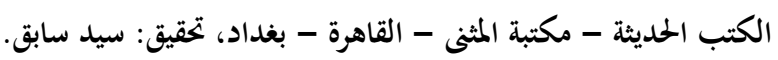

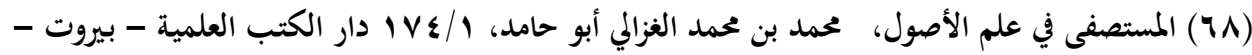

$$
\begin{aligned}
& \text { با 1ا (ا، الطبعة: الأولى، تحقيق: محمد عبد السلام عبد الشافي. }
\end{aligned}
$$

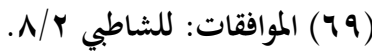

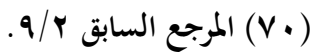

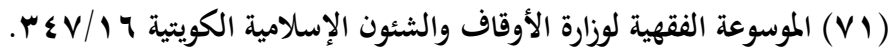

$$
\text { الموافقات Y (VY) }
$$

(VT)

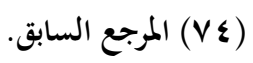

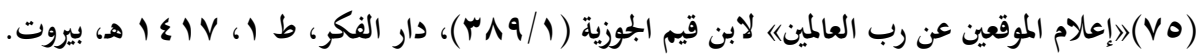

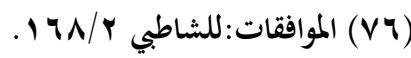

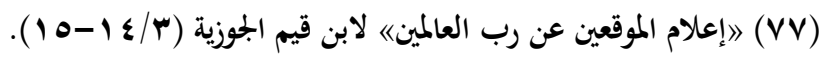

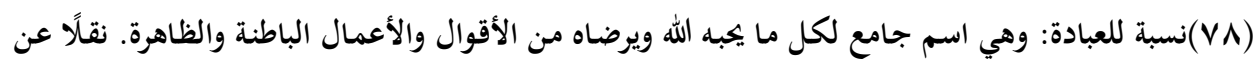

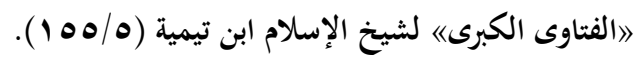

(الموافقات في أصول الشريعة《، أبو إسحاق الشاطبي: إبراهيم بن موسى اللخمي الغرناطي المالكي، دار (V9)

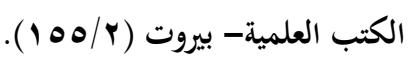

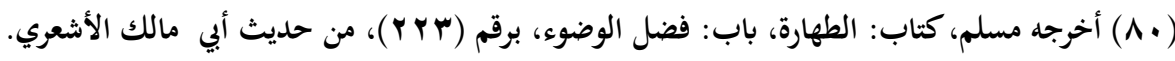




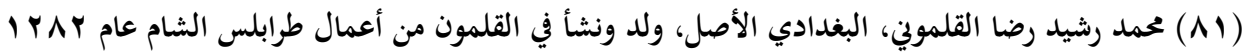

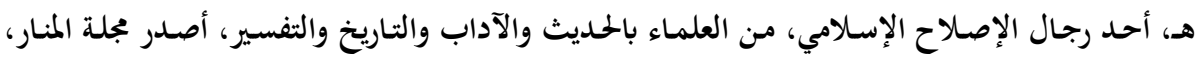

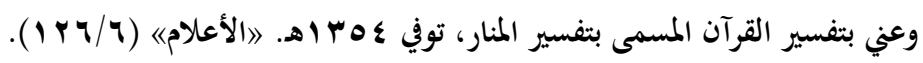

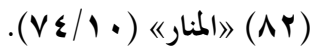

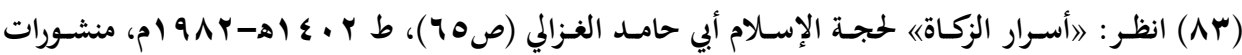

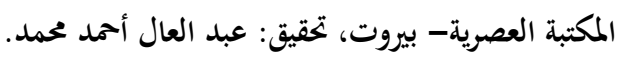

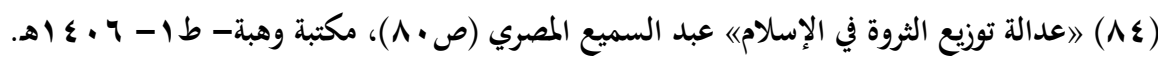

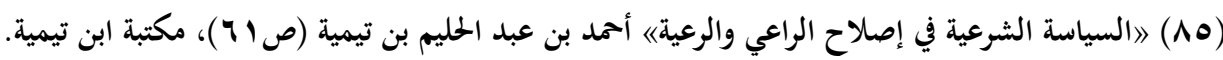

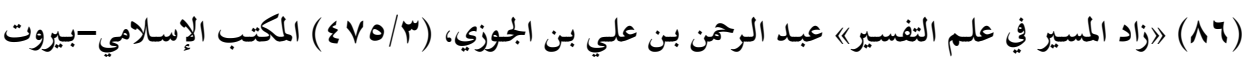

$$
\text { . }
$$

أخرجه أبو داود في 》سننه《، كتاب الزكاة، باب من يعطى من الصدقة وحد الغنى، وهو حديث ضعيف؛ (AV)

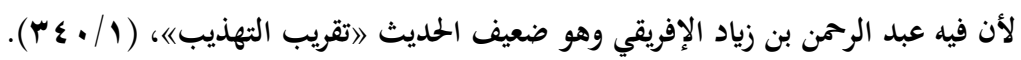

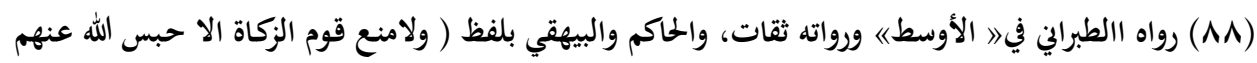

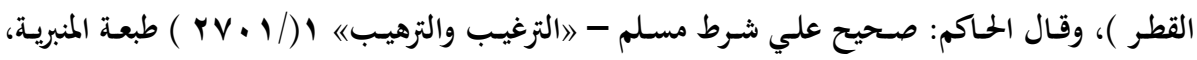

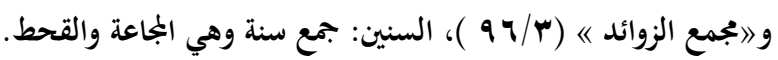
(ه) رواه ابن ماجة والبزار والبيهقي واللفظ له من حديث ابن عمر ورواه الحاكم وصححه ووافقه الذهبي وله

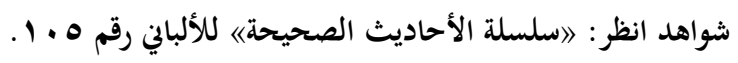

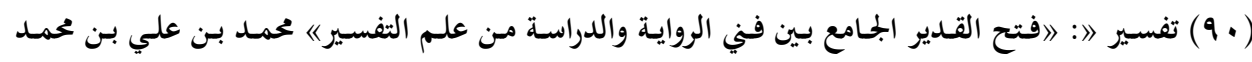

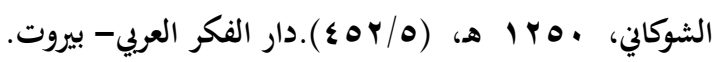

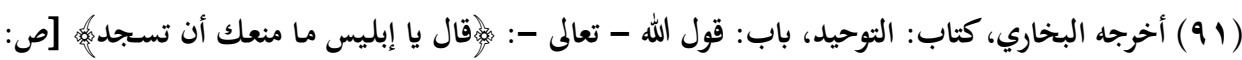

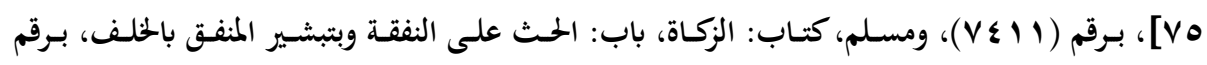

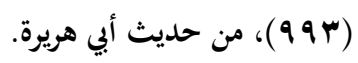

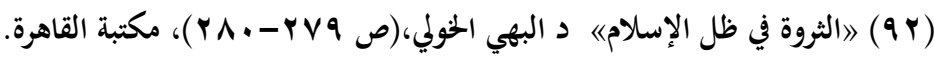

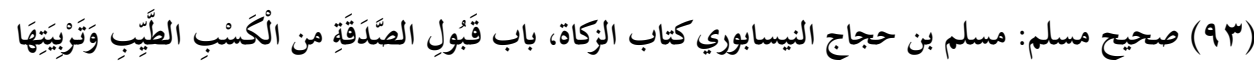

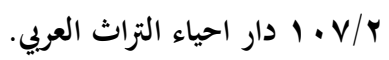

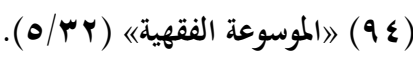

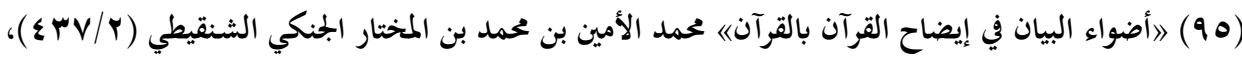

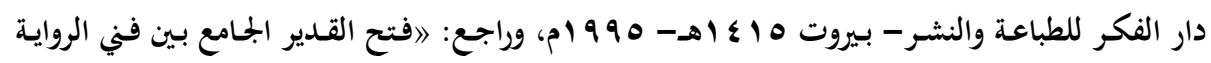

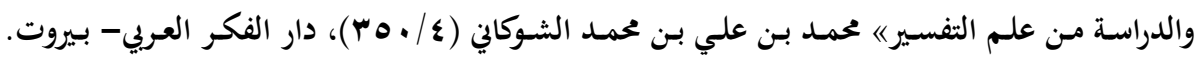




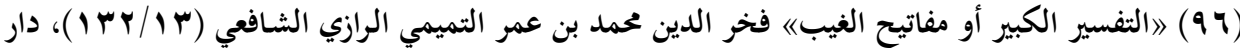

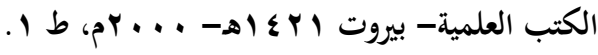

(9V)

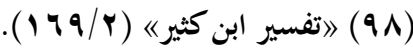

(9 (9) الطرق الحكمية في السياسة الشرعية: 1/ /ه، دار النثر : مطبعة المدني - القاهرة.

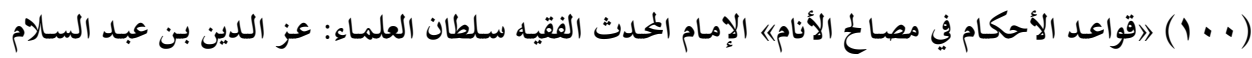

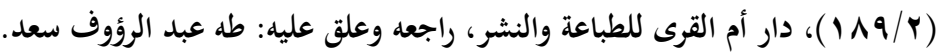

(1 (1 ) وهذا لا يكون إلا باجتهاد الرأي القائم على مراعاة المصالح الشرعية، قال الإمام الجصاص في أحكام

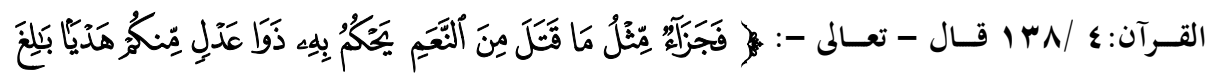

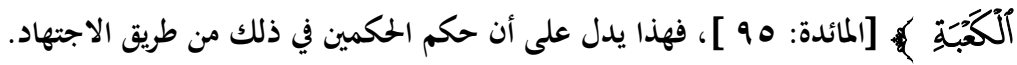

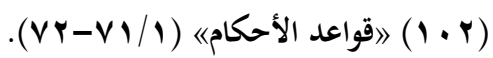

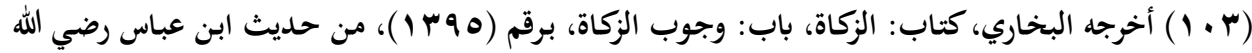

( (1) فتاوى وتوصيات ندوات قضايا الزكاة المعاصرة من الندوة الأولى إلى الثالثة عشرة لبيت الزكاة الكويتي

. (ص)

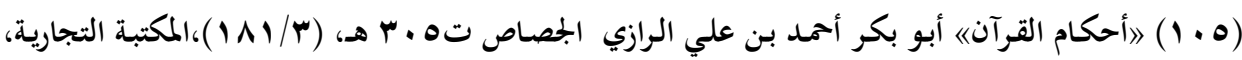
مكة المكرمة.

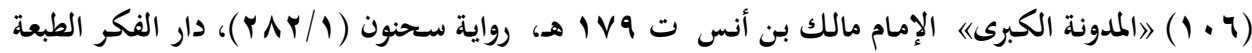

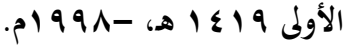

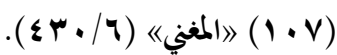

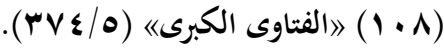

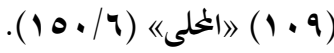

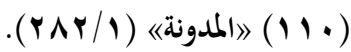

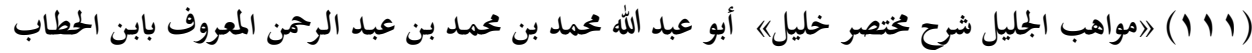

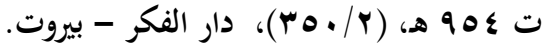

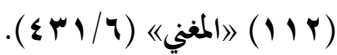

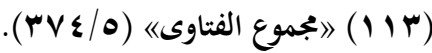

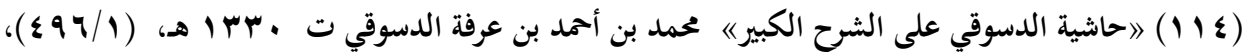

دار إحياء الكتب العلمية. 


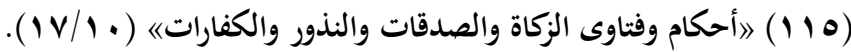

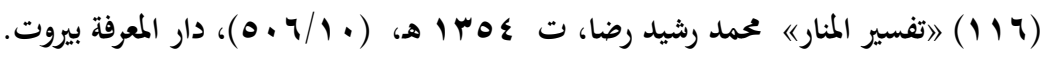

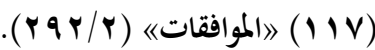

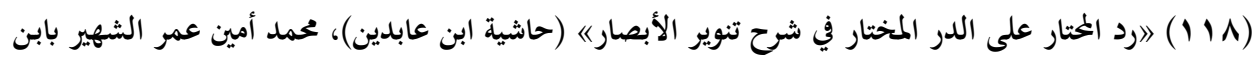

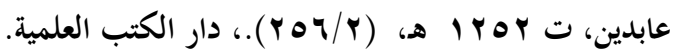

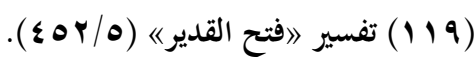

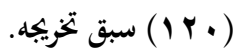

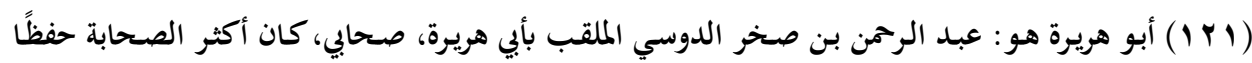

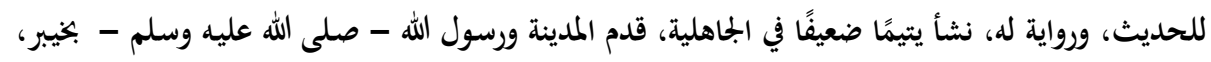

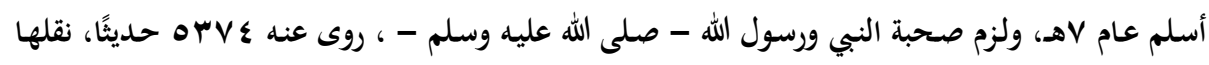

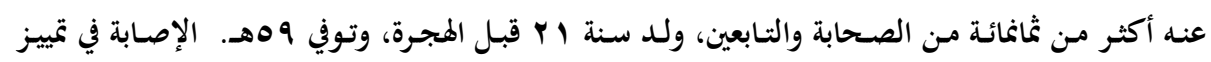

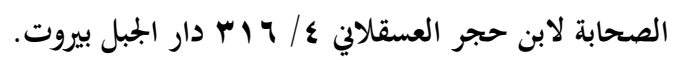

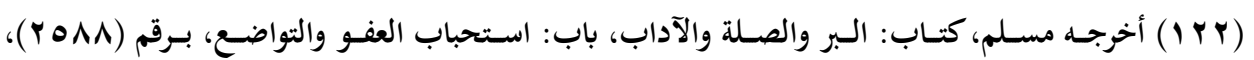

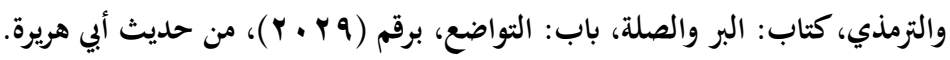

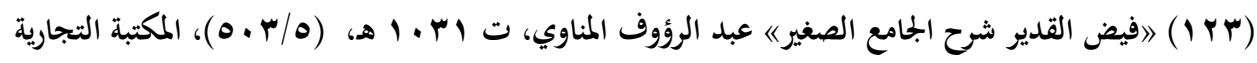

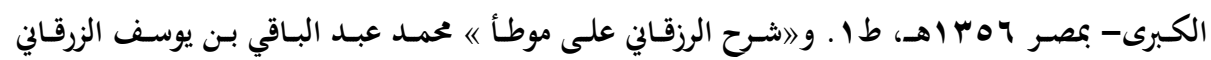

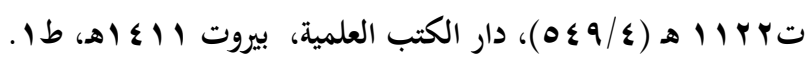

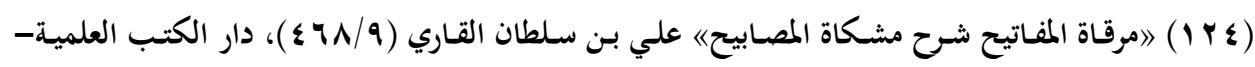

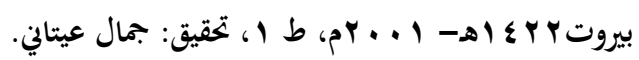

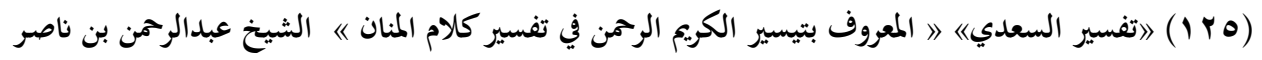

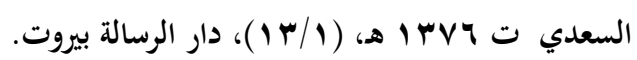
( צ Y ( ) أخرجه البخاري، كتاب: الزكاة، باب: الصدقة من كسب طيب، برقم ( • (1 ( )، ومسلم، كتاب: الزكاة، باب: قبول الصدقة من الكسب الطيب وتربيتها، برقم (ع 1 ـ 1)، من حديث أبي هريرة رضي الله عنه. (I TV)

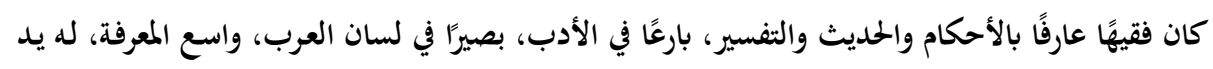

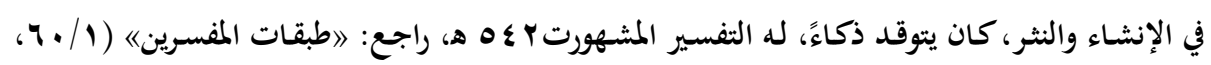

》الخحر الوجيز《 لابن عطية الأندلسي (1/ • ^ץ). 


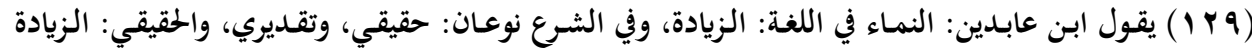
بالتوالد والتناسل والتجارات، والتقديري: تمكنه من الزيادة بكون المال في يده. 》ارد المحتار على الدر المختار)

( $(r q r / 0)$

يقول الكاساني: نعني بـه كون المال معدًا للاستنماء بالتجارة أو الإسامة؛ لأن الإسامة سبب لحصول الدَّرِّ

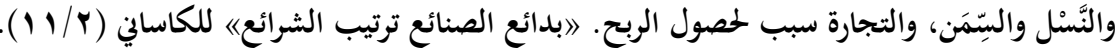

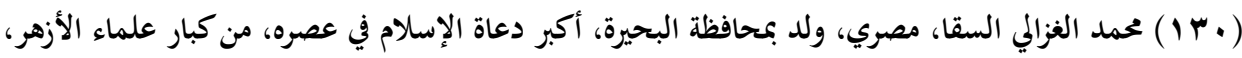

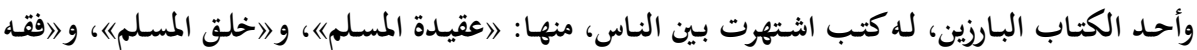
السيرة)، و 》هموم داعية) وغيرها، توفي 999 (م) ودفن في المدينة المنورة بالبقيع. نقلا عن 》فقه الجهاد)

$$
\text { د/يوسف القرضاوي (ص I I I ). }
$$

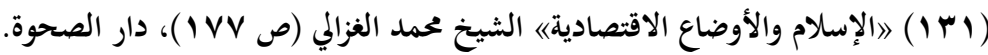
(Y Y ( ) أخرجه الترمذي، كتاب: الزكاة، باب: الزكاة في مال اليتيم، برقم ( ( ؟ )، من حديث عبد الله بن عمرو. وقال الترمذي: في إسناده مقال؛ لأن المثنى بن الصباح يضعف هذا الحديث.

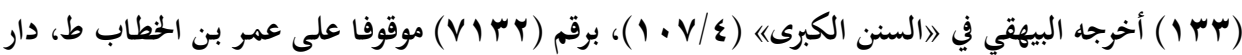

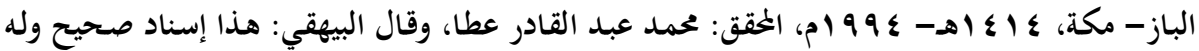

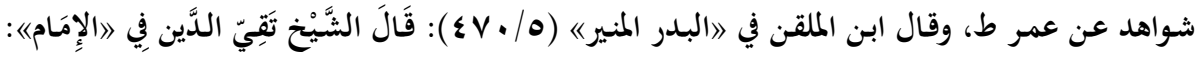

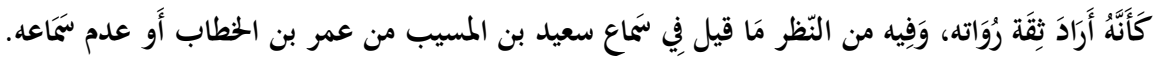

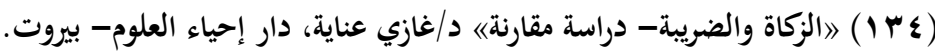

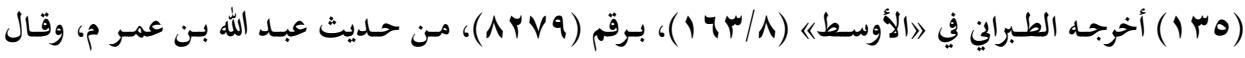

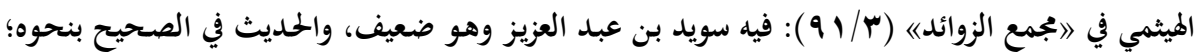

$$
\text { ولكنه موقوف على ابن عمر. }
$$

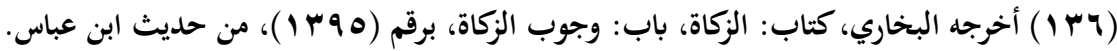

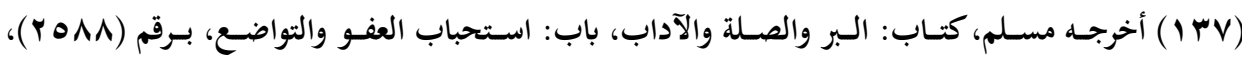

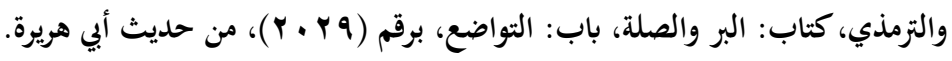

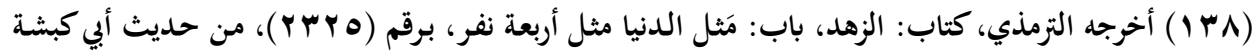

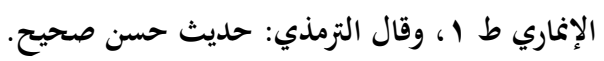

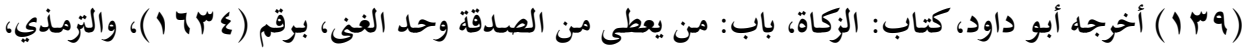
كتاب: الزكاة، باب: من لا تحل الصدقة له، برقم (Y Y Y)، كلاهما من حديث عبد الله بن عمرو م، وقال 
( • ( ) أخرجه أبو داود، كتاب: الزكاة، باب: من يعطى من الصدقة وحد الغنى، برقم (بسج ( )، والنسائي،

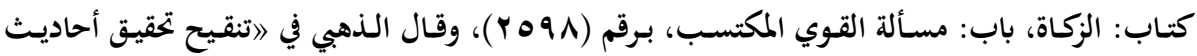

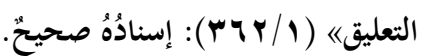

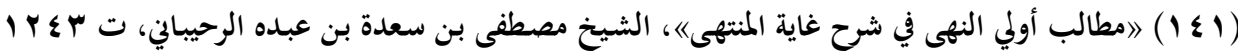

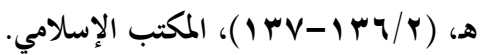

( ) ( ) أخرجه مسلم، كتاب: الطهارة، باب: فضل الوضوء، برقم (TYY)، من حديث إبي ملك الأشعري رضي الله عنه.

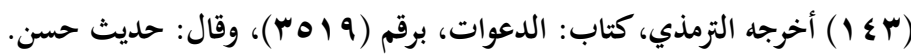

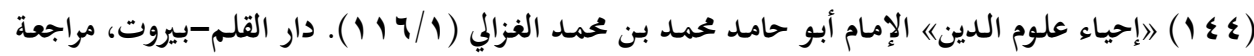

$$
\text { الشيخ: عبد العزيز السيروان. }
$$

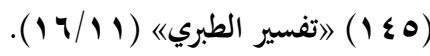

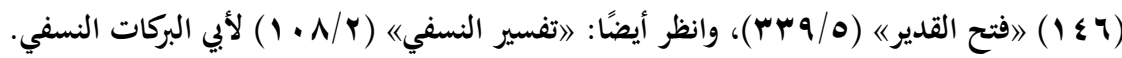

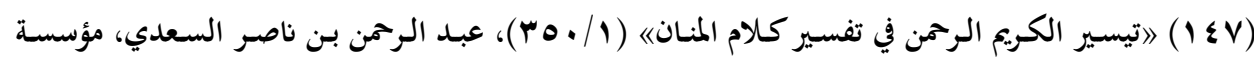

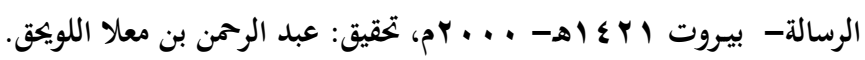

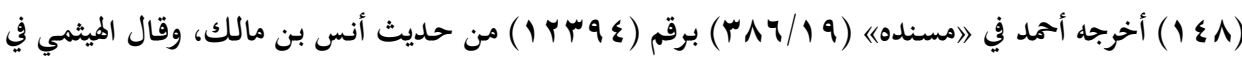

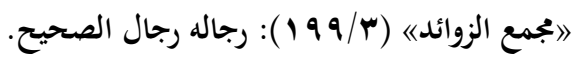

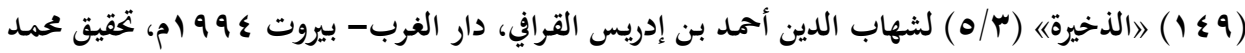
حجي. ( • ( ) أخرجه ابن خزيمة في 》صحيحله)، كتاب: الزكاة، باب: ذكر دليل آخر على أن الوعيد للمكتنز هو لمانع

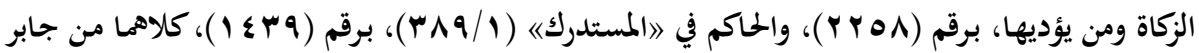
بن عبد الله رضي الله عنهما، وقال الحاكم: حديث صحيح على شرط مسلم ولم يخرجاه. ووافقه الذهبي في

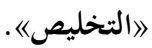
(101) أخرجه مسلم، كتاب: البر والصلة، باب: تحريم الظلم، برقم (YOVA)، من حديث جابر بن عبد الله رضي الله عنه. (10 ( ) حممد بن عمر بن الحسن بن الحسين التميمي البكري، أبو عبد الله فخر الدين الرازي: الإمام المفسر، أوحد زمانه في المعقول والمنقول، ولد في الري عام عهـهـ، من تصانيفه: 》مفاتيح الغيبه في تفسير القرآن،

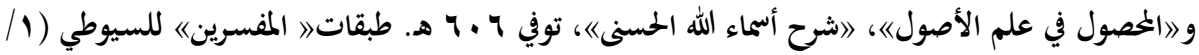

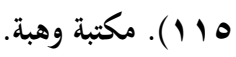

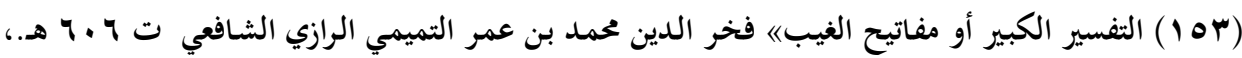

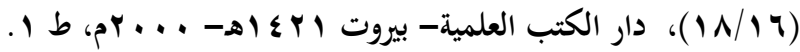




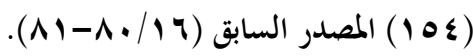

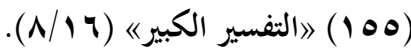

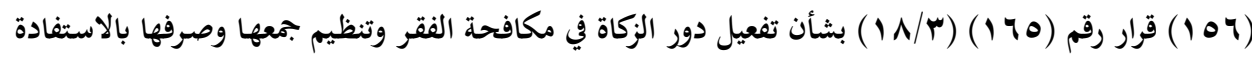

من الاجتهادات الفقهية.

( محمد بن جرير بن يزيد الطبري، أبو جعفر: المؤرخ المفسر الإمام، ولد في آمل طبرستان، واستوطن بغداد

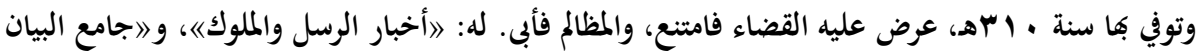

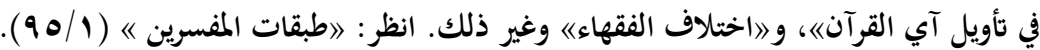

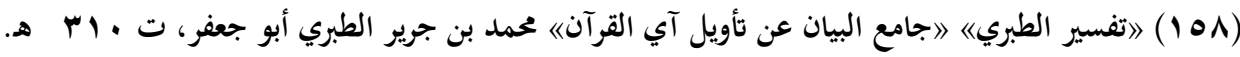

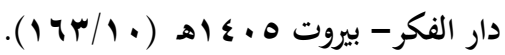

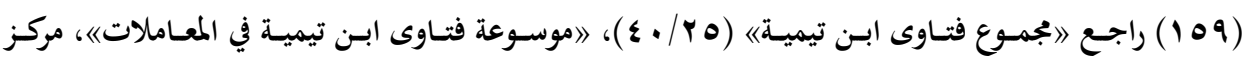

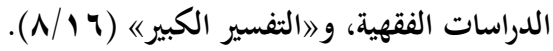

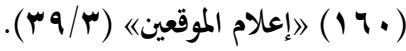

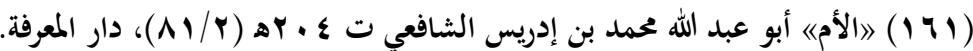

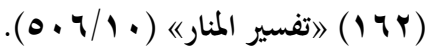

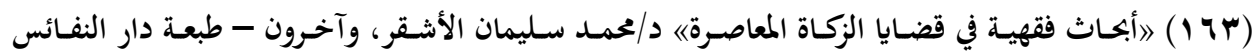
. $\leqslant \leqslant 1 / 1$

( צ 1 ) حذيفة بن حسل بن جابر بن العبسي، أبو عبد الله: صحابي جليل، كان صاحب سرّ رسول الله- صلى

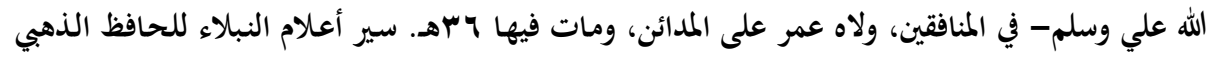

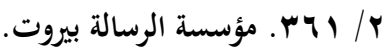
(10 (1) عبد الله بن عباس بن عبد المطلب القرشي الماشيم، أبو العباس: حبر الأمة، الصحابي الجليل، ولد بمكة

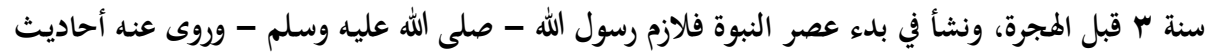

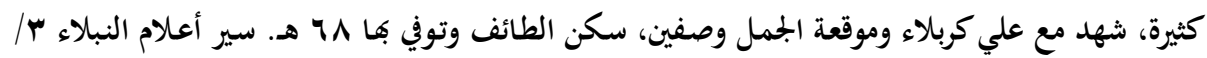
וTr. (7 ( ا ) عكرمة أبو عبد الله مولى ابن عباس أصله بربري ثقه ثبت، عالم بالتفسير، لم يثبت تكذيبه عن ابن عمر

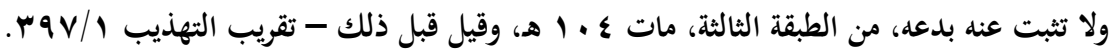
(ITV) عطاء بن أسلم بن صفوان ابن أبي رباح، تابعي من أجلاء الفقهاء، كان عبدًا أسودًا، ولد في اليمن ونشأ بمكة، وكان مفتي أهلها ومحدثهم وتوفي بما. سير أعلام النبلاء ه /

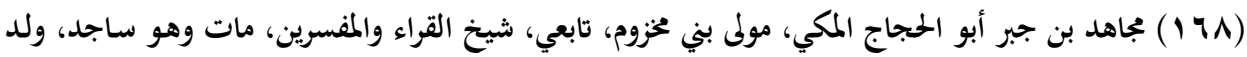

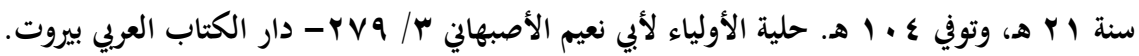

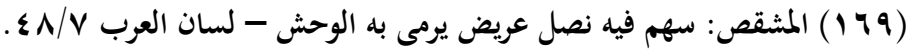


(IV• )

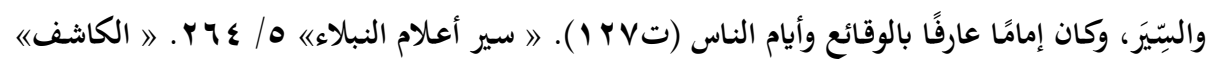

$r \leqslant V / I$

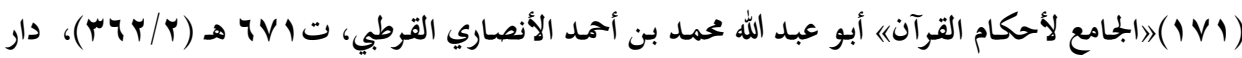

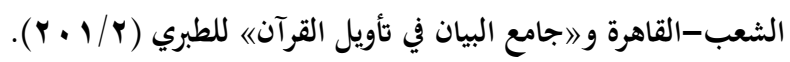

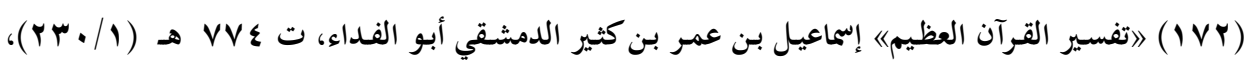

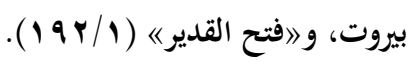
(IVY/Y) 《 (IVT)

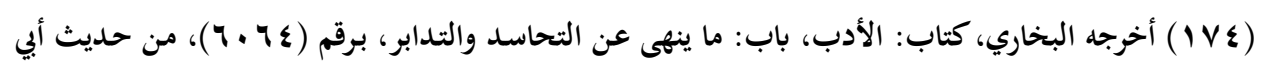
هريرة. (IV0)

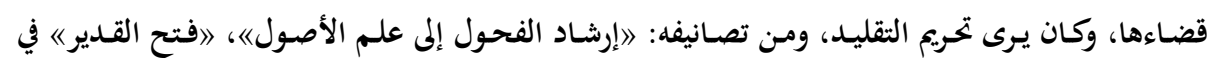

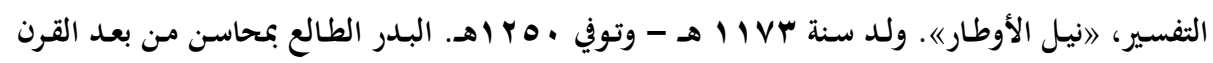

$$
\begin{aligned}
& \text { السابع -دار المعرفة بيروت. }
\end{aligned}
$$

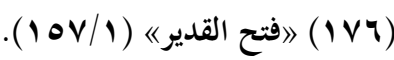

(أنوار التنزيل وأسرار التأويل《 لأبي سعيد عبد الله بن عمر بن محمد الشيرازي البيضاوي ( IVV)

$$
\text { دار الفكر العربي- بيروت. }
$$

عبد الله بن عمر بن محمد بن علي الشيرازي، أبو سعيد أو أبو الحير ناصر الدين البيضاوي، قاض مفسر (IVA)

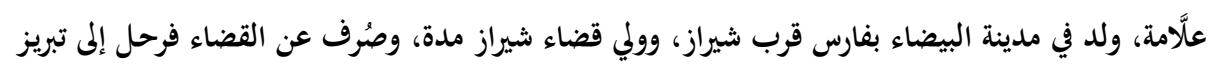

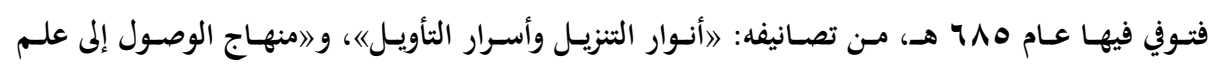

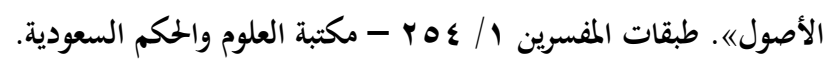

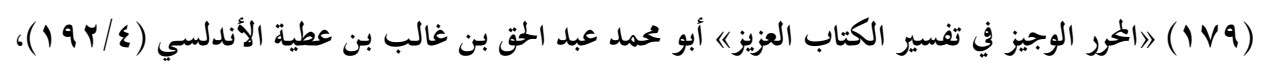

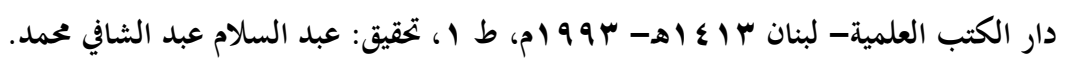

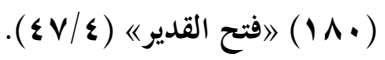

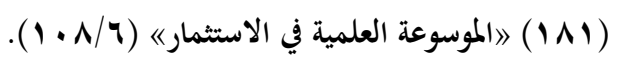

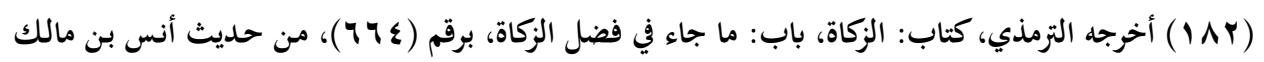
رضي الله عنه، وقال: حديث حسن غريب.

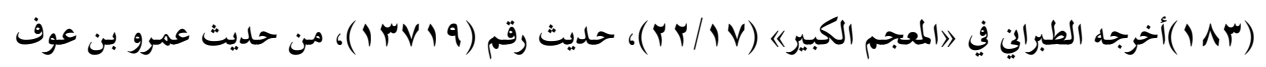

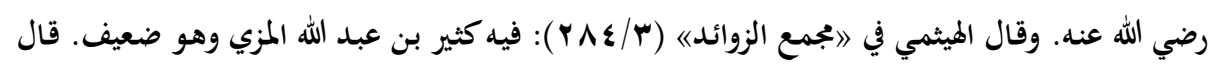


الحافظ المنذري في (الترهيب والترغيب)(Y/ / / ) رواه الطبراني من طريق كثير بن عبد الله عن أبيه عن جده عمرو بن عوف وقد حسنها الترمذي وصححها ابن خزيمة لغير هذا المتن.

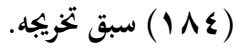

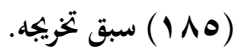

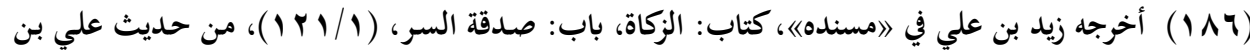
أبي طالب رضي الله عنه.

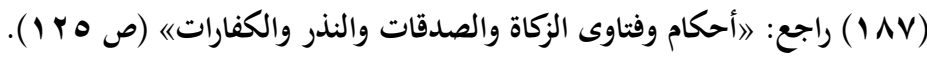

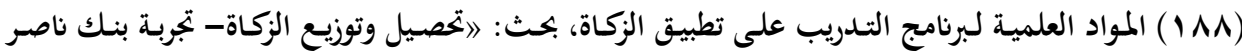

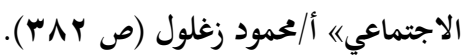

(1 (199 سبق تخريجه. قال أبو عبيد: أهل الذمة يجاهد من دوغم ويفك عناقم، فإذا استنقذوا رجعوا إلى ذمتهم

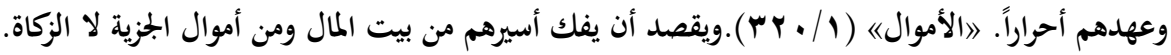

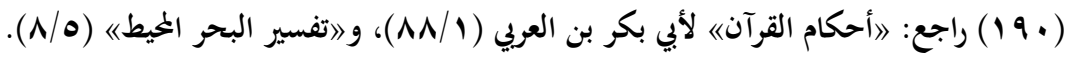

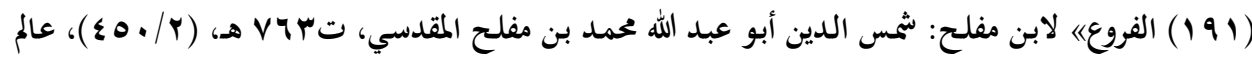

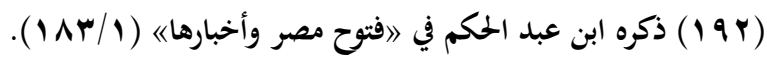

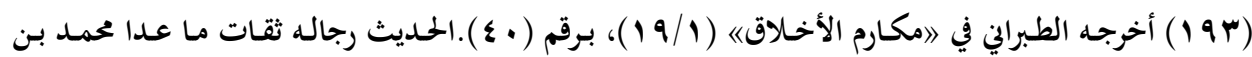

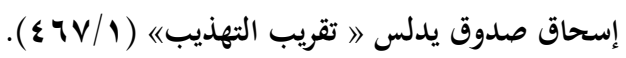

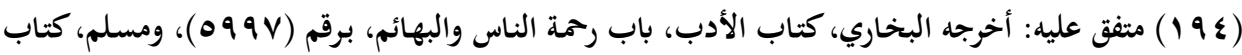

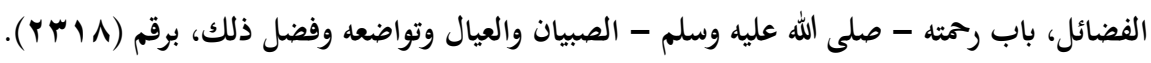

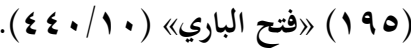

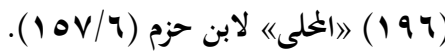

(19V) (صحيح البخاري《 كتاب: الأدب، باب: رحمة الناس والبهائم. 